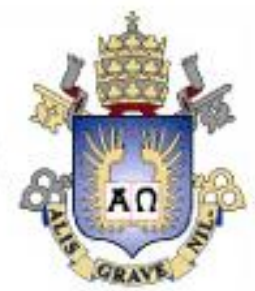

Nathacha Monteiro Ferreira

\title{
A Articulação de Políticas e Atores para a Implementação da Reforma do Ensino Médio no Estado do Mato Grosso
}

\section{Dissertação de Mestrado}

Dissertação apresentada como requisito parcial para obtenção do grau de Mestre pelo Programa de Pós-graduação em Educação, do Departamento de Educação da PUC-Rio.

Orientadora: Prof. Alicia Maria Catalano de Bonamino 


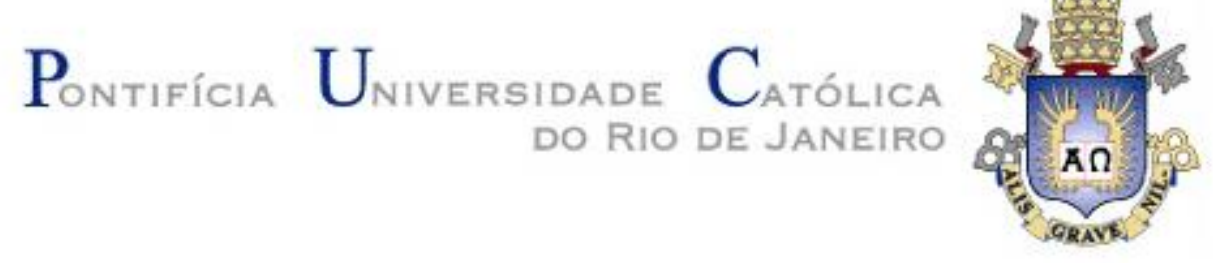

Nathacha Monteiro Ferreira

\begin{abstract}
A Articulação de Políticas e Atores para a Implementação da Reforma do Ensino Médio no Estado do Mato Grosso
\end{abstract}

Dissertação apresentada como requisito parcial para obtenção do grau de Mestre pelo Programa de Pós-Graduação em Educação da PUC-Rio.

Aprovada pela Comissão Examinadora abaixo:

Profa. Alicia Maria Catalano de Bonamino

Orientadora

Departamento de Educação - PUC-Rio

Prof‥ Naira da Costa Muylaert Lima

Departamento de Educação - PUC-Rio

Profa. . Ana Cristina Prado de Oliveira

UNIRIO

Rio de Janeiro, 30 de junho de 2020 
Todos os direitos reservados. É proibida a reprodução total ou parcial do trabalho sem autorização do autor, do orientador e da universidade.

\section{Nathacha Monteiro Ferreira}

Graduada em pedagogia pela Universidade do Estado do Rio de Janeiro - UERJ em 2014. Especialista em orientação educacional e pedagógica pela AVM Faculdade Integrada em 2016. Atua profissionalmente na gestão de projetos sociais em parceria com secretarias de educação estaduais e municipais do Brasil.

Ficha Catalográfica

Ferreira, Nathacha Monteiro

A articulação de políticas e atores para a implementação da reforma do ensino médio no estado do Mato Grosso / Nathacha Monteiro Ferreira ; orientadora: Alicia Maria Catalano de Bonamino. 2020.

122 f. : il. color. ; $30 \mathrm{~cm}$

Dissertação (mestrado)-Pontifícia Universidade Católica do Rio de Janeiro, Departamento de Educação, 2020.

Inclui bibliografia

1. Educação - Teses. 2. Reforma ensino médio. 3. Implementação de políticas. 4. Políticas públicas. 5. Estado do Mato Grosso. I. Bonamino, Alicia Maria Catalano de. II. Pontifícia Universidade Católica do Rio de Janeiro. Departamento de Educação. III. Título. 
À minha mãe, que sempre foi minha fonte de inspiração, força e resiliência.

Às crianças e jovens do Brasil. 


\section{Agradecimentos}

A Deus pela vida.

A minha mãe e meu pai por todo o amor e cuidado dispensados a mim e pelo apoio que tornou possível essa jornada. Ao meu irmão, por me fazer rir nos momentos de preocupação e por todo o apoio e amizade. Nossa família tem seus muitos desafios, mas me fortalece. Amo vocês!

A minha querida orientadora, Alicia Bonamino, pela sua sabedoria, paciência com a minha escrita e doçura durante todo o processo. Você é uma pessoa inspiradora, sou muita grata pelos aprendizados ao longo desse processo.

Aos meus familiares, por sempre acreditarem em mim e torcerem pelo meu sucesso. Durante a pesquisa minha família aumentou e isso me deu mais força e alegria para seguir fazendo o meu melhor. Muito obrigada Gigi e João, meus afilhados, vocês me fazem mais feliz e completa. Obrigada Lala e Renata por trazê-los ao mundo e me tornarem dinda.

A Márcia Florêncio e Júnior Diniz, vocês são os responsáveis por essa conquista. Muito obrigada por terem acreditado em mim e me motivado. Vocês me inspiram de muitas maneiras e sou eternamente grata pela amizade e carinho.

As minhas amigas que acompanharam todo o processo, sentiram minha ausência e sempre torceram pelo meu sucesso: Elza Stille, Sarah Horsai, Jéssica Soares, Thais Oliveira, Larissa Geromel, Camila Roza, Natália Clarkson, Natália Palácio, Priscila Flores e Thalitta Pivar. 
A coordenação executiva do Cieds, Vandré Brilhante, Fábio Muller e Roselene Souza por todos os aprendizados ao longo desses anos e por incentivarem e apoiarem a minha formação e crescimento. Aos amigos queridos conquistados na instituição: Ana Muniz, José Claudio, Aldeli Carmo, Loren Almeida, Marina Rotenberg, Roberta Castro, Douglas Ripper, Isabel Salgado e Fernanda Colmenero, que foi minha parceira de estudos, perrengues e comemorações.

As minhas corajosas e brilhantes companheiras dessa jornada acadêmica, em 2018 iniciamos juntas o mestrado e criamos laços tão especiais. As nossas trocas e apoio foram fundamentais para essa caminhada. Admiro e torço muito por cada uma dessas nove mulheres pesquisadoras.

Aos colegas do grupo de pesquisa Laboratório da Avaliação da Educação - LAEd, pelo acolhimento e trocas substanciais para a pesquisa. Vocês são feras!

A secretaria estadual de educação de Mato Grosso pela autorização para a realização da entrevistas e partilha dos dados. À Rose Fialho pelo apoio para a realização da pesquisa.

O presente trabalho foi realizado com apoio da Coordenação de Aperfeiçoamento de Pessoal de Nível Superior - Brasil (CAPES) - Código de Financiamento 001. 


\section{Resumo}

Ferreira, Nathacha Monteiro; Bonamino, Alicia Maria Catalano de. A articulação de políticas e atores para a implementação da reforma do ensino médio no Estado do Mato Grosso. Rio de Janeiro, 2020. 122p. Dissertação de mestrado - Departamento de Educação, Pontifícia Universidade Católica do Rio de Janeiro.

A dissertação tem por objeto de estudo as atuais políticas educacionais dirigidas ao Ensino Médio, com foco na análise da Reforma do Ensino Médio e sua implementação no estado do Mato Grosso. A reforma surgiu via a Medida Provisória (MP) nº746 de 2016, e faz parte das estratégias de gestões recentes do Governo Federal voltadas para a melhoria da qualidade da educação, envolvendo a reestruturação desta etapa de ensino.

Em termos metodológicos, é uma pesquisa qualitativa que acompanhou o processo inicial de implementação da reforma do ensino médio, a partir da análise de documentos nacionais e estaduais e de entrevistas com atores do alto e do médio escalão da Secretaria Estadual de Educação do Estado de Mato Grosso (SEE-MT). O contexto de implementação da reforma envolve regras, relações federativas entre o Governo Federal e o Estado e entre o Estado e os Municípios, além de atores burocráticos estatais e de atores não estatais, que são analisados a partir de referenciais da Ciência Política, notadamente do binômio ambiguidade-conflito de Matland (1995), das relações entre camadas federativas e níveis burocráticos de Hupe e Hill (2003) e da visão da política pública como um processo incremental de Lindblom (1979).

Conclui-se que a implementação da reforma do ensino médio no estado do Mato Grosso tem, ao menos, duas características marcantes, que podem ser interpretadas à luz das categorias "contexto experimental de implementação", "incrementalismo" e das relações que se estabelecem entre o estado e o Governo Federal. A reforma do ensino médio acontece em Mato Grosso em um contexto de implementação experimental. Além de a reforma apresentar um baixo grau normatização e de indução pelo Governo Federal, o que torna sua proposta mais ambígua, existe no estado um baixo nível de questionamento sobre a necessidade da reforma. Trata-se de um contexto em que as formas de implementação da 
reforma ainda não têm uma definição precisa do Governo Federal e parecem seguir a mesma lógica incremental que vem sendo adotada pelo estado nas próprias iniciativas de mudança que já vem acontecendo no ensino médio. Há poucas iniciativas estatais prévias de mudança no ensino médio estadual mato-grossense e as que existem acontecem de maneira incremental, aos poucos, acompanhando a capacidade de indução e de incentivo do Governo Federal e a experiência acumulada pelo estado. Isso faz com que, nesta etapa da implementação, o estado do Mato Grosso esteja dando prioridade àquelas dimensões da reforma que se mostram mais bem sintonizadas com iniciativas já em curso e também mais aderentes às propostas do MEC, como acontece claramente com a proposta de ampliação da oferta de escolas de tempo integral.

\section{Palavras-Chave}

Reforma ensino médio; Implementação de políticas; Políticas públicas; Estado do Mato Grosso. 


\section{Abstract}

Ferreira, Nathacha Monteiro; Bonamino, Alicia Maria Catalano de (Advisor). The articulation of policies and actors for the implementation of high school reform in the State of Mato Grosso. Rio de Janeiro, 2020. 122p. Dissertação de Mestrado - Departamento de Educação, Pontifícia Universidade Católica do Rio de Janeiro.

The purpose of this dissertation is to study the following educational policies aimed at high school, focusing on the analysis of high school reform and its implementation in the state of Mato Grosso. The reform came about via Provisional Measure (MP) n 746 of 2016, and is part of the Federal Government's recent management strategies aimed at improving the quality of education, involving the restructuring of this teaching stage.

In methodological terms, it is a qualitative research that accompanied the initial process of implementing the reform of high school, based on the analysis of national and state documents and interviews with high and middle level actors from the State Department of Education of the State of Mato Grosso (SEE-MT). The context of implementation of the reform involves rules, federative relations between the Federal Government and the State and between the State and the Municipalities, in addition to state bureaucratic and non-state actors, which are analyzed based on Political Science references, notably from the ambiguity-conflict binomial of Matland (1995), of the relations between federal layers and bureaucratic levels of Hupe and Hill (2003) and of the view of public policy as an incremental process by Lindblom (1979).

It is concluded that the implementation of the reform of secondary education in the state of Mato Grosso has, at least, two remarkable characteristics, which can be interpreted in the light of the categories "experimental context of implementation", "incrementalism" and the relationships that are established between the state and the Federal Government. High school reform takes place in Mato Grosso in a context of experimental implementation. In addition to the reform presenting a low degree of regulation and induction by the Federal Government, which makes its proposal more ambiguous, there is a low level of questioning in the state about the need for reform. It is a context in which the ways of 
implementing the reform do not yet have a precise definition by the Federal Government and seem to follow the same incremental logic that has been adopted by the state in the very change initiatives that have already been happening in high school. There are few previous state initiatives for change in the state high school of Mato Grosso and those that exist happen incrementally, little by little, following the capacity of induction and incentive of the Federal Government and experience accumulated by the state. This means that, at this stage of implementation, the state of Mato Grosso is giving priority to those dimensions of reform that are more in line with initiatives already underway and also more adherent to MEC's proposals, as is clearly the case with the expansion proposal of offering full-time schools.

\section{Keywords}

Reform of high school; implementation of policies; Public policies; State of Mato Grosso. 


\section{Sumário}

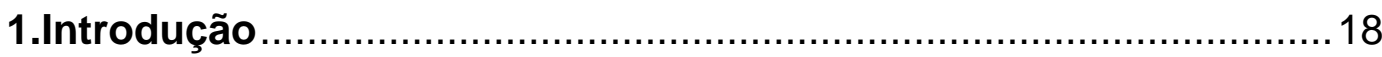

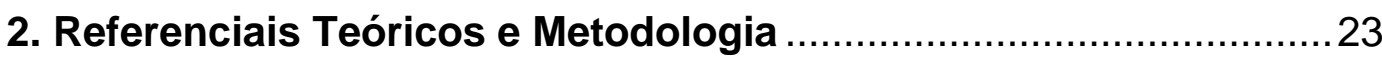

2.1 Contextos de Implementação de Políticas Públicas .......................23

2.2 Relações entre Camadas Federativas e Níveis Burocráticos .........28

2.3 O modelo incrementalista na análise de políticas públicas .............29

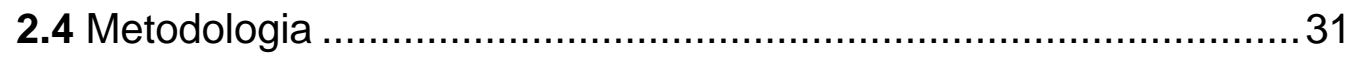

3. $O$ Ensino Médio e as Políticas Educacionais ..................................38

3.1 - O Ensino Médio e as Políticas Educacionais: contextualização ...38

3.2 - A medida provisória n 746, de 2016: A Reforma do Ensino Médio 45

3.3 - A Reforma do Ensino Médio e seus desdobramentos na sociedade 49

3.4 - A Reforma do Ensino Médio nos Estados Brasileiros: olhar para a implementação de uma política 54

3.5 - A parceria entre o poder público e o $3^{\circ}$ setor na implementação de

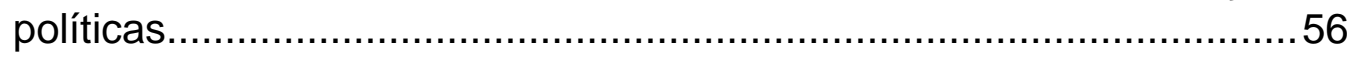

4. A Política Educacional do Estado do Mato Grosso ……................58

4.1 - Contextualização socioeconômica do Mato Grosso ......................58

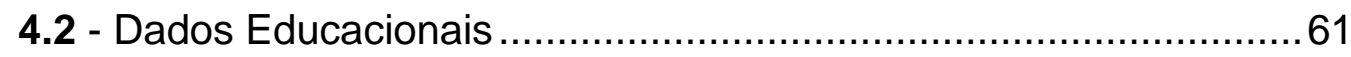

4.3 - Políticas Educacionais ............................................................ 70

5. O Currículo e o Novo Ensino Médio no estado do Mato Grosso ..77

5.1 - Relações federativas e burocráticas na implementação do Novo Ensino Médio no estado de Mato Grosso ..........................................77

5.2 - Incrementalismo e experimentalismo na reforma mato-grossense

5.3 - Contexto de implementação do Novo Ensino Médio: ambiguidade e

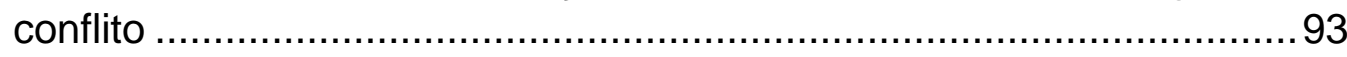

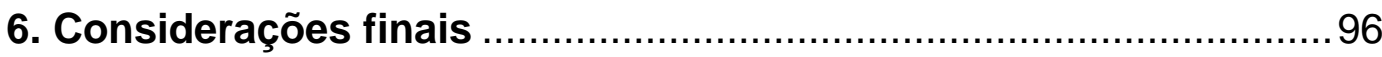

7. Referências bibliográficas ..................................................... 103

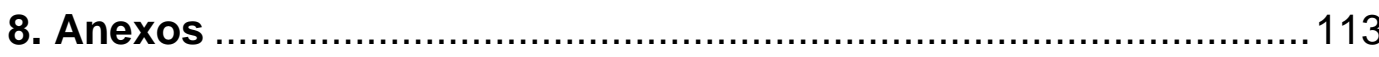




\section{Lista de tabelas}

Tabela 1 - Índice de desenvolvimento humano - IDH........................62 62

Tabela 2 - Número de matrículas - Ensino Médio............................63 63

Tabela 3 - Panorama de matrículas na Educação Infantil no Mato Grosso........................................................................................... 64

Tabela 4 - Panorama de matrículas no Ensino Fundamental no Mato Grosso.................................................................................. 64

Tabela 5 - Panorama de matrículas no Ensino Médio no Mato

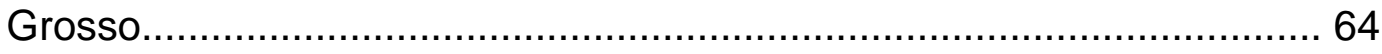

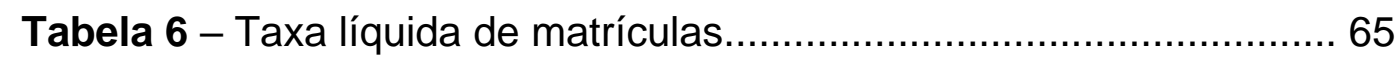

Tabela 7 - Percentual de jovens de 19 anos que concluíram o Ensino Médio. 66

Tabela 8 - Percentuais de aprovação, abandono e aprovação no Ensino Médio. 66

Tabela 9 - Evolução das notas do SAEB no Ensino Médio 67 


\section{Lista de Gráficos}

Gráfico 1 - Número de escolas de Ensino Médio no Mato Grosso .......68 68

Gráfico 2 - Número de docentes que atuam no Ensino Médio no Mato Grosso .........................................................................................

Gráfico 3 - Evolução do IDEB no Brasil e Mato Grosso ...................... 69 


\section{Lista de Quadros e Figuras}

Quadro 1- Contextos de implementação: ambiguidade e conflito........... 27

Figura 1 - Mapa com a localização dos Cefapros ........................... 74 


\section{Lista de abreviaturas}

ANDE - Associação Nacional de Educação

ANDES - Associação Nacional de Docentes do Ensino Superior

ANPED - Associação Nacional de Pesquisa e Pós-Graduação em Educação

BID - Banco Interamericano de Desenvolvimento

BNCC - Base Nacional Comum Curricular

CAQ - Custo Aluno Qualidade

CBA - Ciclo Básico de Aprendizagem

CEE - Coordenadoria de desenvolvimento do Ensino Médio

CEFRAPO - Centros de Formação e Atualização dos Profissionais da Educação Básica de Mato Grosso

CNE - Conselho Nacional de Educação

CNTE - Confederação Nacional dos trabalhadores da Educação

CONSED - Conselho Nacional dos Secretários Estaduais de Educação

EM - Ensino Médio

EMIEP - Ensino Médio Integrado a Educação Profissional

EMTI - Ensino Médio em Tempo Integral

ENEM - Exame Nacional do Ensino Médio

EPT - Educação Profissional e Tecnológica

FIEMT - Federação das Indústrias no Estado de Mato Grosso

FUNDEB - Fundo de Manutenção e Desenvolvimento da Educação Básica e de Valorização dos profissionais da Educação

IBGE - Instituto Brasileiro de Geografia e Estatística

IDEB- Índice de Desenvolvimento da Educação Básica

IDH - Índice de Desenvolvimento Humano

IF - Institutos Federais de Educação, Ciência e Tecnologia

INEP - Instituto Nacional de Estudos e Pesquisas Educacionais Anísio Teixeira

LDB - Lei de diretrizes e bases da educação básica

LDB - Lei de diretrizes e Bases da Educação Básica

MEC - Ministério da Educação

MP - Medida Provisória

PDDE - Programa Dinheiro Direto na Escola 
PEE - Plano Estadual de Educação

PIB - Produto Interno Bruto

PL- Projeto de Lei

PNAIC - Pacto nacional pela Alfabetização na Idade Certa

PNAID - Programa Nacional de Formação de Agente de Inclusão Digital

PNE - Plano Nacional da Educação

ProBNCC - Programa de Apoio à Implementação da Base Nacional Comum Curricular

ProEMI - Programa Ensino Médio Inovador

PRONATEC - Programa Nacional de Acesso ao Ensino Técnico e Emprego

REM - Reforma do Ensino Médio

SAEB - Sistema Nacional de Avaliação da Educação Básica

SEE - MT - Secretaria Estadual de Educação do Estado de Mato Grosso

SENAC - Serviço Nacional de Aprendizagem do Comércio

SENAI - Serviço Nacional de Aprendizagem Industrial

SENAR - Serviço Nacional de Aprendizagem Rural

SESC - Serviço Social do Comércio

SESCOOP - Serviço Nacional de Aprendizagem do Cooperativismo

SESI - Serviço Social da Indústria

SEST - Serviço Social de Transporte

UBES - União Brasileira dos estudantes Secundaristas

UNDIME - União Nacional dos Dirigentes Municipais de Educação

UNEMAT - Universidade do Estado de Mato Grosso 
Educação não transforma o mundo.

Educação muda as pessoas.

Pessoas transformam o mundo.

(Paulo Freire) 


\section{Introdução}

A presente pesquisa tem por objeto as atuais políticas educacionais dirigidas ao Ensino Médio, com foco na análise da Reforma do Ensino Médio e sua implementação no estado do Mato Grosso. A reforma surgiu via a Medida Provisória (MP) nº746 de 2016, e faz parte das estratégias de gestões recentes do Governo Federal e do Ministério da Educação (MEC) voltadas para a "melhoria da qualidade da educação" e que envolvem a reestruturação do Ensino Médio. A seleção do estado do Mato Grosso como objeto do estudo empírico considera as características do contexto estadual de implementação e a limitada quantidade de estudos que contemplam a Região Centro Oeste, aspectos que serão apresentados no capítulo destinado à metodologia.

Após os investimentos realizados e das políticas desenvolvidas para a universalização do Ensino Fundamental, verificam-se os desafios postos ao Ensino Médio, que é considerado o gargalo da educação e um dos focos das políticas educacionais brasileiras atuais.

Além do financiamento originalmente voltado apenas ao Ensino Fundamental via FUNDEF, que vigorou de 1997 a 2006, há uma longa lista de investimentos dirigidos à universalização desse nível de ensino, com destaque para outros programas do Governo Federal, como a descentralização dos recursos dos programas federais da merenda escolar e do livro didático, e a criação de novos programas de fomento, como o Programa Dinheiro Direto na Escola (PDDE) ${ }^{1}$, o Pacto Nacional pela Alfabetização na Idade Certa (PNAIC) ${ }^{2}$, Mais Educação ${ }^{3}$,

\footnotetext{
${ }^{1}$ O PDDE consiste na assistência financeira às escolas públicas da educação básica das redes estaduais, municipais e do Distrito Federal e às escolas privadas de educação especial mantidas por entidades sem fins lucrativos. O objetivo desses recursos é a melhoria da infraestrutura física e pedagógica, o reforço da autogestão escolar e a elevação dos índices de desempenho da educação básica. (Portal MEC, acesso em 30 de maio de 2019)

2 O PNAIC tem o objetivo de criar estratégias para que, ao final do $3^{\circ}$ ano do Ensino Fundamental, todas as crianças estejam alfabetizadas. (Brasil, 2012)

3 O Programa Mais Educação tem por finalidade contribuir para a melhoria da aprendizagem por meio da ampliação do tempo de permanência de crianças, adolescentes e jovens matriculados em escola pública, mediante oferta de educação básica em tempo integral. (Brasil, 2010)
} 
Implantação de Salas de Recursos Multifuncionais ${ }^{4}$, o Programa Gestão de Aprendizagem Escolar ${ }^{5}$, e a criação da Avaliação Nacional da Alfabetização (ANA) $)^{6}$, entre outros dirigidos ao Ensino Fundamental. No Ensino Médio, o Governo Federal tem sido menos ativo na proposição de programas e políticas educacionais envolvendo transferência de recursos, no contexto de estados mais ativos que conduzem iniciativas próprias, muitas das vezes de forma independente. Ainda assim, podemos citar entre as iniciativas federais dirigidas ao Ensino Médio, o Programa Ensino Médio Inovador ${ }^{7}$, o Exame Nacional do Ensino Médio $(\text { ENEM })^{8}$, o Programa de Fomento às Escolas de Ensino Médio em Tempo Integral (EMTI)entre outros.

Apesar dessas e de outras iniciativas, há problemas persistentes que afetam os ensinos Fundamental e Médio. Em que pese a universalização do acesso ao Ensino Fundamental, refletida no acesso de 97,7\% das crianças dos 6 aos 14 anos à escola, dados do Censo Escolar 2017 mostram a persistência da reprovação que faz com que $24,1 \%$ dos jovens de 16 anos não concluam essa etapa da educação básica na idade adequada.

A reprovação e a conclusão tardia do Ensino Fundamental têm reflexos no Ensino Médio, como mostram recentes indicadores educacionais calculados a partir de dados da PNAD Contínua9. Em 2017, 90,8\% da população de 15 a 17 anos estavam na escola, mas a taxa liquida, ou seja, aquela que compreende os jovens de

\footnotetext{
${ }^{4}$ O Programa integra o Plano de Desenvolvimento da Educação - PDE, destinando apoio técnico e financeiro aos sistemas de ensino para garantir o acesso ao ensino regular e a oferta do Atendimento Educacional Especializado - AEE aos alunos com deficiência, transtornos globais do desenvolvimento e/ou altas habilidades/superdotação. (MEC, 2010)

${ }^{5}$ O Programa Gestão da Aprendizagem Escolar oferece formação continuada em língua portuguesa e matemática aos professores dos anos finais (do sexto ao nono ano) do ensino fundamental em exercício nas escolas públicas. (Portal MEC, acesso em 01 de junho de 2019)

${ }^{6}$ A Avaliação Nacional da Alfabetização (ANA) é uma avaliação externa que objetiva aferir os níveis de alfabetização e letramento em Língua Portuguesa (leitura e escrita) e Matemática dos estudantes do $3^{\circ}$ ano do Ensino Fundamental das escolas públicas. (MEC, 2013)

${ }^{7}$ O Programa Ensino Médio Inovador é uma ação do Ministério da Educação para a elaboração do redesenho curricular nas escolas de Ensino Médio e contribui para disseminar a cultura para o desenvolvimento de um currículo mais dinâmico e flexível, que contemple os conhecimentos das diferentes áreas numa perspectiva interdisciplinar e articulada à realidade dos estudantes, suas necessidades, expectativas e projetos de vida. (MEC, 2017)

${ }^{8}$ O ENEM é realizado anualmente, com o objetivo fundamental de avaliar o desempenho do aluno ao término da escolaridade básica, para aferir o desenvolvimento das competências fundamentais ao exercício pleno da cidadania. (MEC, 2019)

${ }^{9}$ A Pesquisa Nacional por Amostra de Domicílios Contínua - PNAD Contínua tem como objetivo produzir indicadores para acompanhar as flutuações de curto prazo e a evolução, a médio e longo prazos, da força de trabalho e outras informações necessárias para o estudo e desenvolvimento socioeconômico do País. (IBGE,2015)
} 
15 a 17 anos matriculados no Ensino Médio, era de apenas 67,5\%. De acordo com os dados, cerca de 2 milhões de jovens de 15 a 17 anos ainda estão no Ensino Fundamental e outros 903,1 mil não estudam e não concluíram o Ensino Médio.

O quadro se completa com os dados do Sistema Nacional de Avaliação da Educação Básica (SAEB) de 2017 referentes ao desempenho dos estudantes em leitura e matemática no $3^{\circ}$ ano do Ensino Médio. Esses dados indicam que em matemática apenas 4,52\% dos jovens estão no nível adequado, seguidos de $23,81 \%$ de jovens no nível básico ${ }^{10}$ e $71,67 \%$ de jovens no nível insuficiente ${ }^{11}$, sendo que destes $22,49 \%$ estão no nível zero ou abaixo do básico. Os dados referentes a português apresentam um panorama mais preocupante, apenas 1,64\% dos jovens estão no nível adequado, seguidos de 27,5\% de jovens no nível básico e 70,88\% considerados no nível insuficiente, sendo que, destes, 23,9\% estão no nível zero. Esses dados indicam que a aprendizagem esperada não ocorreu nos anos escolares correspondentes para praticamente dois terços dos alunos e que, no Ensino Médio, as dificuldades acumuladas ao longo da trajetória escolar aparecem em sua máxima expressão.

Diante desse cenário, justifica-se a importância de se estudar a principal política nacional que atualmente visa a definir as finalidades e a organização do Ensino Médio, isto é, a reforma dessa etapa da educação básica introduzida por MP em 2016 e regulada pela Lei 13.415/2017.

A pesquisa enfatiza especialmente questões envolvidas com a implementação dessa política, adotando referências de autores da ciência política e de estudos recentes sobre a formulação dessa reforma pelo Governo Federal e sobre sua implementação no âmbito dos estados brasileiros.

São escassos os estudos sobre a reforma que a analisam enquanto política pública. Uma busca pelas produções nessa perspectiva nos permitiu ter acesso à dissertação de mestrado Educação em disputa: uma análise sobre os conflitos decorrentes da reforma do ensino médio no Brasil sob o prisma do modelo de

\footnotetext{
${ }^{10}$ Os alunos neste nível precisam melhorar. Sugere-se atividades de reforço (PORTAL DO QEDU, 2020) Disponível em <https://www.qedu.org.br/> Acesso em 02.07.2020.

${ }^{11}$ Os alunos neste nível apresentaram pouquíssimo aprendizado. É necessária a recuperação de conteúdos (PORTAL DO QEDU, 2020) Disponível em <https://www.qedu.org.br/> Acesso em 02.07.2020.
} 
coalizões de defesa, defendida por Carvalho (2019) na Universidade Federal Rural do Rio de Janeiro - UFRRJ. Essa dissertação analisa a dinâmica conflituosa do campo de políticas educacionais do Brasil, mostrando os interesses em disputa em torno da MP de 2016, à luz do Modelo de Coalizações de Defesa de Sabatier (1987).

Também fazem parte dessa produção os artigos Efeito de mudanças no contexto de Implementação de uma política multinível: análise do caso da Reforma do Ensino Médio no Brasil e Trajetórias de Implementação de mudanças no Ensino Médio nos estados brasileiros: impactos da Lei 13.415/2017. Tratam-se de dois estudos derivados de pesquisa conduzida por Lotta, Bauer, Rojas e Jobim (2019; 2020). O primeiro examina os processos prévios de mudanças no Ensino Médio dos 27 estados, aos quais se sobrepôs a reforma. O segundo analisa as diferentes configurações dos contextos estaduais de implementação dessa reforma à luz do binômio ambiguidade-conflito (Matland, 1995) e das relações federativas e burocráticas (Hupe e Hill, 2003) envolvidas no processo de implementação.

O contexto específico de implementação da reforma no estado do Mato Grosso envolve regras, relações federativas entre o Governo Federal e o estado e entre o estado e os municípios, além de atores burocráticos estatais e de atores não estatais, que serão analisadas a partir de referenciais de análise da ciência política, notadamente do binômio ambiguidade-conflito de Matland (1995) e das relações entre camadas federativas e níveis burocráticos de Hupe e Hill (2003). Esse contexto estadual também envolve experiências prévias de mudança no Ensino Médio que incidem sobre o processo de implementação da reforma. Segundo a perspectiva incrementalista, na implementação de reformas, contextos que possuem experiências prévias de mudança tenderiam a dar prioridade àquelas dimensões da reforma que se mostram mais bem sintonizadas com iniciativas já em curso e com as concepções de seus agentes implementadores. (Lindblom, 1979)

Assim, levando em conta a complexidade das relações federativas e burocráticas (Matland, 1995; Hupe e Hill, 2003) envolvidas na implementação da reforma e também o modelo de análise incrementalista (Lindblom, 1979), definimos os seguintes objetivos de pesquisa:

- Compreender as relações federativas e burocráticas que se estabelecem na implementação da reforma do Ensino Médio no estado do Mato Grosso. 
- Identificar o papel desempenhado por experiências prévias de mudança na configuração do contexto atual de implementação da reforma do Ensino Médio no estado do Mato Grosso.

A dissertação está estruturada em cinco capítulos. O primeiro apresenta a introdução da dissertação, com a delimitação do tema estudado, os objetivos da pesquisa e sua contextualização. O segundo capítulo apresenta os referenciais teóricos da pesquisa e a metodologia utilizada, considerando sua natureza e abordagem, a definição do objeto de estudo - o estado do Mato Grosso - e o método e instrumentos de coleta. O terceiro capítulo apresenta uma caracterização desta etapa da educação básica à luz tanto de documentos oficiais como das políticas dirigidas mais recentemente a essa etapa da educação básica, de modo a contextualizar a chegada da nova reforma e seus impactos, assim como as influências presentes nesse cenário. No quarto capítulo são apresentadas as políticas educacionais do estado do Mato Grosso, a caracterização do território, dados educacionais e o Plano Estadual de Educação, para possibilitar uma melhor compreensão do contexto estadual de chegada da reforma. O quinto capítulo apresenta os resultados do trabalho empírico, e a análise do processo de implementação da reforma no estado. Esse capítulo possibilita conhecer o contexto de implementação da reforma no Mato Grosso, considerando a influência de suas ações prévias, as mudanças causadas com a chegada da nova política, a participação de atores estatais e não estatais e como a rede está se estruturando para a implementação da reforma. Por fim, são apresentadas as conclusões finais, que articulam os principais elementos revelados pela pesquisa. 


\section{Referenciais Teóricos e Metodologia}

Compreender as relações federativas e burocráticas que se estabelecem na implementação da reforma do Ensino Médio no estado do Mato Grosso; identificar as características do contexto de implementação da reforma a partir da percepção de atores estatais; e identificar as iniciativas prévias de mudança, são as principais finalidades da pesquisa. Essa compreensão remete ao tipo de contexto de implementação produzido nas interações entre formulação e implementação (MATLAND, 1995); à problemática das relações intergovernamentais e entre níveis burocráticos (HUPE e HILL, 2003) e às mudanças prévias no Ensino Médio estadual e seu grau de institucionalização (LOTTA, 2020).

\subsection{Contextos de Implementação de Políticas Públicas}

A produção de literatura sobre implementação de políticas públicas é relativamente recente, e vem se consolidando nos últimos 30 anos no sentido de compreender como a execução da política se efetiva no interior do Estado. Nessa busca se desenvolveram dois tipos de abordagens: top-down e bottom-up. A primeira busca verificar os mecanismos que levariam a implementação se aproximar da formulação da política. A segunda se baseia no pressuposto de que a implementação modifica a formulação.

A abordagem top-down se caracteriza por adotar uma perspectiva normativa e prescritiva, focada nos processos de tomada de decisão. Essa abordagem assume a implementação como um processo hierárquico, de cima para baixo, no qual os agentes devem executar a política de acordo com os objetivos formulados. Essa compreensão dirige o olhar dos pesquisadores para a formulação da política e para as estruturas mais elevadas de poder, o alto escalão, os tecnocratas e suas decisões. 
A segunda abordagem se desenvolve no final dos anos de 1970 e início de 1980. A abordagem bottom-up é mais analítica e tem como pressuposto que o processo de implementação transforma e adapta as políticas originais. Em razão disso, as análises bottom-up investigam uma vasta gama de atores que interagem no nível local de implementação das políticas públicas, focalizando a "base" das cadeias hierárquicas, os contextos de entrega das políticas, serviços e benefícios para cidadãos ou organizações, e as burocracias de nível de rua.

$\mathrm{Na}$ tentativa de avançar para além da dicotomia criada entre essas duas abordagens, surgem, entre os anos de 1980 e 1990, novas análises que propõem uma síntese, ao mesmo tempo em que passam a considerar diferentes planos analíticos (HILL e HUPE, 2009; WINTER, 2006).

Matland (1995) é um dos autores que propõe uma abordagem da implementação de políticas públicas baseada numa síntese entre modelos top-down e bottom-up, tornando-se por isso um autor chave para entender as mudanças e as tendências que se desenham na constituição dos contextos de implementação de uma determinada política. De acordo com o autor, o problema é que os modelos de implementação bottom-up desconsideram o ambiente de tomada de decisão ou o ambiente de formulação, na análise sobre como as políticas acontecem no campo. Para Matland, os modelos de análise precisam considerar que a formulação faz parte da implementação e que a implementação atravessa a cadeia decisória dos diferentes atores. Com base nessa compreensão, o autor propõe a junção de formulação e implementação a partir de duas variáveis que são centrais nos estudos organizacionais: conflito e ambiguidade. Seu interesse é entender como as variáveis ambiguidade e conflito permeiam as decisões dos atores envolvidos com uma determinada política. O autor considera que toda política pública é marcada por algum grau de conflito e de ambiguidade, tanto na formulação como na implementação. O conflito tem a ver com o quanto os atores discordam em relação aos fins ou aos meios da política pública. Já a ambiguidade diz respeito ao grau de incerteza que a política pública promove para os atores agirem. Para Matland (1995) conflito e ambiguidade são duas variáveis que podem: ser gerenciadas, aparecer em graus diferentes e se transformar ao longo do tempo.

No modelo de análise de Matland (1995) o processo de formulação de uma política cria condições para o contexto de implementação por meio de leis, muito 
gerais ou muito rígidas, ou seja, mais ou menos ambíguas, que criam diferentes graus de incerteza e fazem com que os atores se comportem de maneiras diferenciadas. Uma normatização muito rígida da política produz menor ambiguidade ou incerteza e deixa pouco espaço para os atores promoverem ajustes ao contexto local e para o exercício da discricionariedade. Regras muito rígidas podem, no entanto, serem improdutivas, pois inibem a flexibilidade dos implementadores no campo de ação. Já uma baixa regulamentação da política, pode criar maiores incertezas e o risco de uma excessiva flexibilização.

No entanto, segundo Matland (1995), a ambiguidade também pode se configurar como um dos caminhos para se evitar e superar conflitos mesmo na fase de elaboração da política devido à necessidade de equacionamento de interesses e objetivos divergentes.

O fator conflito está, assim, relacionado à interdependência entre os atores e a possíveis divergências com relação aos objetivos e às finalidades da política em questão.

Ambiguidade e conflito podem existir em diferentes graus e combinações, gerando diferentes contextos de implementação. Matland (1995) apresenta quatro contextos possíveis, a saber: implementação administrativa, implementação experimental, implementação política e implementação simbólica.

Quadro 1- Contextos de implementação: ambiguidade e conflito

\begin{tabular}{|c|c|c|}
\hline & Baixo conflito & Alto conflito \\
\hline $\begin{array}{c}\text { Baixa } \\
\text { Ambiguidade }\end{array}$ & $\begin{array}{l}\text { Implementação administrativa } \\
\text { Recursos determinam resultados; } \\
\text { Sistemas fechados tecnocráticos. }\end{array}$ & $\begin{array}{c}\text { Implementação política } \\
\text { Poder determina implementação; } \\
\text { Aberto a influências; } \\
\text { Tentativa de assegurar compliance }\end{array}$ \\
\hline $\begin{array}{c}\text { Alta } \\
\text { ambiguidade }\end{array}$ & $\begin{array}{l}\text { Implementação experimental } \\
\text { Contexto determina processos; } \\
\text { Muitos atores de poder; } \\
\text { Negociação e criação. }\end{array}$ & $\begin{array}{c}\text { Implementação simbólica } \\
\text { Novos valores; } \\
\text { Novos objetivos; } \\
\text { Depende da força de coalização. }\end{array}$ \\
\hline
\end{tabular}

Fonte: Matland, R.E. (1995). Traduzido por Lotta et al (2020) 
A implementação administrativa acontece quando existe baixa ambiguidade $\mathrm{e}$ baixo conflito. São políticas que propiciam um conhecimento claro de seus objetivos e dos meios para alcançá-los e que apresentam resultados e entregas bastante previsíveis, pois tendem a ser executadas de maneira padronizada e por atores com baixo grau de discricionariedade. A implementação administrativa apresenta baixo uso de coerção e um ambiente estável com pouca ou nenhuma influência externa (LOTTA et al, 2020; BRUNS et al, 2015). Quando uma política apresenta alto grau de concordância entre os atores e as formas de alcance dos objetivos são conhecidas, a implementação decorre de forma técnica e burocrática, tendo como entrave apenas a disponibilidade de recursos. Esse é o caso, por exemplo, das políticas de vacinação contra o sarampo e de emissão de documentos (identidade; passaporte; etc.).

A implementação experimental é caracterizada por um alto nível de ambiguidade e um baixo nível de conflito, já que nela geralmente não há o questionamento sobre a necessidade da política, e há abertura para a negociação de resultados e meios. No contexto experimental, a implementação está mais aberta a influências locais e à ocorrência do experimentalismo, o que propicia que os atores adaptem e interpretem a política no processo de implementação. Seus resultados dependem dos atores e dos recursos do ambiente, seu foco central está na negociação e na criação e geralmente acontece em contextos federativos ou de implementação de políticas novas (LOTTA et al, 2020; BRUNS et al, 2015). A criação de um contexto de implementação experimental é recomendada quando os objetivos da política e seus meios são ainda desconhecidos ou as formas de implementação não têm ainda uma definição mais precisa. Nesse contexto, o baixo nível de conflito permite a participação e envolvimento de uma diversidade de atores interessados na implementação da política e também deixa espaço significativo para a autonomia e discricionariedade dos implementadores. As pesquisas biomédicas são um exemplo deste tipo de implementação, pois a tecnologia para a implementação ainda não é plenamente conhecida, mas há um grande apelo público para sua implementação, como mostram atualmente a multiplicidade de pesquisas no mundo em busca de uma vacina contra a COVID19. 
A implementação política é caraterizada por um baixo nível de ambiguidade e um alto nível de conflito. Acontece em situações na qual o governo inclui um tema na agenda e decide implementá-lo, mesmo quando há conflitos. A ideia subjacente é que os resultados da implementação de uma política são decididos pelo poder. Este contexto comporta forte influência do contexto político, que se utiliza de coerção e de incentivos, para superar, sem enfrentamento, o conflito. Em geral, são políticas que introduzem temas altamente conflitivos, como as políticas antidrogas, por exemplo (LOTTA et al, 2020; BRUNS et al, 2015).

A implementação simbólica acontece em ambientes com alto nível de ambiguidade e alto nível de conflito, que evidenciam as dificuldades enfrentadas na execução da política. As políticas de implementação simbólica abrangem valores, símbolos e princípios, que normalmente geram conflito, mesmo sendo elas bastante ambíguas. São políticas formuladas sem que estejam presentes as condições necessárias para a implementação e que têm por objetivo chamar a atenção para a obtenção de apoio político. O impacto das políticas simbólicas se caracteriza pela simples repercussão do enunciado que a sua elaboração e vigência podem causar. Essa implementação geralmente envolve um objeto de disputa, introduz novos valores ou objetivos que demandam o posicionamento do governo, mas não incluem a mobilização de recursos para sua implementação. A sua ambiguidade dificulta seu monitoramento local e pode gerar resultados diferentes, mas a tendência é que essa implementação não gere resultados efetivos, razão pela qual é chamada de simbólica (LOTTA et al, 2020; BRUNS et al, 2015).

A segunda dimensão relevante para a compreensão do contexto de implementação de políticas diz respeito a como as políticas são adaptadas, interpretadas e reformuladas quando passam pelas múltiplas camadas e níveis de atores, como acontece com a Reforma do Ensino Médio, política formulada pelo Governo Federal e que precisa passar pelos estados e municípios e chegar até às escolas e salas de aula. 


\subsection{Relações entre camadas federativas e níveis burocráticos}

Para analisar a implementação é importante compreender quem decide sobre o quê e como as políticas são alteradas ao longo das camadas decisórias (Hill \& Hupe, 2003). Essa ideia vem do pressuposto de que há, em geral, uma grande distância entre os formuladores das políticas e seus executores finais (ARRETCHE, 2001). Distância esta que provoca contingências na implementação em razão de decisões tomadas por uma cadeia de implementadores alocados em contextos políticos e institucionais diversos (LOTTA, 2015). Portanto, para compreender os processos de implementação de uma política, é preciso analisar as camadas decisórias pelas quais ela passa.

A literatura propõe dois conceitos centrais: implementação multinível (multilevel) e implementação em múltiplas camadas (multi-layering).

A primeira caracteriza quase todas as políticas e diz respeito às diferentes partes que coexistem no ciclo de política pública, e que não têm autonomia para alterar decisões. (HILL \& HUPE, 2003). É o caso, por exemplo, das camadas hierárquicas organizacionais ou burocráticas envolvidas com a reforma do Ensino Médio nas coordenadorias regionais e nas escolas.

Já a implementação multi-layering diz respeito às camadas de diferentes governos que exercem autoridade e têm legitimidade e competência territorial para tomar decisões com autonomia, como acontece nos contextos federativos, onde há uma separação de competências entre diversos entes e atores (governos estaduais/governadores; prefeituras/prefeitos, e dirigentes e secretários da educação, por exemplo) com legitimidade decisória (HILL \& HUPE, 2003). Essa distinção é importante porque marca a diferença entre quem tem mandato legítimo para transformar a política e reformulá-la e quem não o tem, o que acaba por interferir na atuação cotidiana de quem tenta executar o que foi formulado (HILL \& HUPE, 2003).

Quanto mais camadas e níveis, maior a complexidade da implementação, já que a política pode ser alterada nos diferentes espaços e nas diferentes interações entre atores políticos e burocráticos (LOTTA ET AL, 2020). 
Esse é o caso da reforma do Ensino Médio que foi formulada pelo Governo Federal para ser implementada pelos estados e suas escolas e, portanto, em contextos que já possuem iniciativas prévias de mudança no Ensino Médio, o que nos remete ao modelo incrementalista de análise de políticas.

\subsection{O modelo incrementalista na análise de políticas públicas}

A terceira referência da pesquisa é o modelo de decisão incremental. Segundo esse modelo, na implementação de novas políticas os atores tenderiam a dar prioridade àquelas dimensões que se mostram mais bem sintonizadas com iniciativas anteriores e em curso, e, ainda, com as concepções de seus agentes implementadores. Assim, o modelo incremental, que tem como principais autores Lindblom (1979), Caiden e Wildavsky (1980) e Wildavisky (1992), ressalta a importância do passado para a implementação de novas políticas.

A visão da política pública como um processo incremental leva em conta que os recursos governamentais para um programa, órgão ou uma política específica não se iniciam do zero, mas acontecem por meio de decisões incrementais. As decisões passadas possuem grande relevância, pois constrangem decisões futuras e limitam a capacidade dos governos de implementar novas políticas ou de mudar o planejamento atual (SOUZA, 2006; ARANHA e FILGUEIRAS, 2016).

Lindblom (1979) considera que os processos de tomada de decisão por parte dos atores políticos podem ser classificados como simples e complexos. Os de natureza simples estão relacionados às decisões racionais, onde é possível analisar e ponderar as variáveis intervenientes e o problema é restrito. Nos de natureza complexa os administradores abandonam a racionalidade e utilizam a abordagem analítica method of sucessive limited comparisons, ou incrementalista (PEREIRA et al, 2010).

O modelo incremental identifica o processo decisório a partir de uma perspectiva política, considerando suas limitações e fragmentações. Envolve uma política realizada em pequenos passos, que não geram mudanças drásticas no modelo estabelecido. Se baseia em um processo de revisão contínua das ações, 
tomando decisões incrementais a partir do comportamento anterior, sem envolver, necessariamente, a busca de uma solução ótima ou o alcance de uma situação ideal. (SOUZA, 2006; PEREIRA et al, 2010).

Nesse sentido, as políticas vão se transformando em pequenos passos, ou seja, pequenos valores são adicionados, representando ajustes marginais às estruturas, que evitam uma ruptura institucional (ARANHA, FILGUEIRAS, 2016).

Lindblom (1959, p. 84-86) defende que o processo de decisão política possui as seguintes características: (i) é construído passo a passo, através de mudanças incrementais, com base em políticas preexistentes; (ii) envolve ajustamentos mútuos e negociação, e (iii) não é uma solução final para os problemas, é apenas um passo que, quando bem-sucedido, pode ser seguido de outros.

Ou seja, as politicas são construídas e reconstruídas de maneira sucessiva, sua construção advém de aproximações ao objetivo pretendido, que pode sofrer alterações. Esta análise inclui as relações de poder nos processos de tomada de decisão, os processos eleitorais e o próprio papel das burocracias e dos grupos de interesse (ARAÚJO e RODRIGUES, 2020).

Assim, os autores indicam que as políticas públicas não se caracterizam por decisões fechadas, sendo antes feitas e refeitas constantemente, em um processo de cadeia de escolhas sucessivas para mitigação de riscos e acomodação de ajustes mútuos entre atores políticos e grupos envolvidos. Esse processo maximiza a segurança nas mudanças realizadas e melhora a qualidade da política por meio de um aprendizado sistemático. Porém esse modelo também apresenta riscos, como o fechamento de possibilidades devido à forte ligação com o passado, e a possível realização de mudanças importantes, através de pequenos incrementos, sem o debate público.

A literatura utilizada na pesquisa contribui para a compreensão da reforma do ensino médio e a sua implementação no estado do Mato Grosso. Matland (1995) permite compreender as características do contexto de implementação, Hupe e Hill (2003) permitem analisar as relações entre o Governo Federal e o estado e entre a secretaria e as escolas, enquanto Lindblom (1979) permite analisar a importância de iniciativas prévias de mudança na implementação da reforma. A 
contextualização da reforma à luz desses referenciais compõe o capítulo 5, que analisa a reforma no estado do Mato Grosso.

\subsection{Metodologia}

Nesta seção será apresentada a metodologia de pesquisa adotada no estudo, considerando sua natureza e abordagem, a justificativa para a escolha do estado do Mato Grosso como objeto de estudo empírico, a apresentação dos sujeitos participantes da pesquisa e a coleta de informações.

\section{Natureza e abordagem da pesquisa}

Em termos metodológicos, foi conduzida uma pesquisa qualitativa que acompanhou o processo inicial de implementação da reforma do Ensino Médio no Mato Grosso, a partir da análise de documentos nacionais e estaduais, e de entrevistas com atores do alto e do médio escalão da Secretaria Estadual de Educação do Estado de Mato Grosso (SEE-MT).

Segundo Denzin e Lincoln (2006) a pesquisa qualitativa pressupõe uma abordagem interpretativa, atribuindo significados aos fenômenos a partir dos atores envolvidos. Nesta perspectiva, Vieira e Zouain (2005) salientam que a pesquisa qualitativa preza pela descrição dos fenômenos e dos elementos que o envolvem, atribuindo grande importância às narrativas dos atores envolvidos no estudo e entendendo seus discursos e os significados transmitidos. Ao se considerar as características da pesquisa qualitativa e o objetivo da pesquisa, destacam-se os estudos de Creswel (2007, p.186) para quem, na perspectiva qualitativa, o ambiente natural se torna a fonte direta dos dados e o pesquisador assume o papel de principal instrumento. Na pesquisa qualitativa a preocupação com o processo ganha maior centralidade em contrapartida ao produto, pois o interesse do pesquisador é verificar "como" o problema de pesquisa se manifesta nas atividades, procedimentos e interações cotidianas.

Dentro do campo de pesquisas qualitativas, e a partir dos objetivos informados na introdução, esta pesquisa pode ser definida como uma pesquisa 
exploratória, pois pretende se familiarizar com um assunto ainda pouco conhecido ou explorado.

Assim, optou-se pela utilização da estratégia de estudo de caso e essa escolha se justifica, segundo Yin (2015, p. 15), pois "o estudo de caso tem uma vantagem diferenciada quando uma questão "como" ou "por que" está sendo feita sobre um conjunto de eventos contemporâneos, algo que o pesquisador tem pouco ou nenhum controle".

Considerando, com base no modelo de Matland (1995), que a implementação de uma política como a reforma do Ensino Médio pode ensejar diferentes contextos em função também das capacidades e do histórico de mudanças nos estados, a pesquisa optou pelo estudo de caso em um estado brasileiro específico. A seleção do estado considerou a relevância da contribuição do estudo para uma região pouco abordada, conforme explicitado na próxima seção.

\section{Definição do objeto de estudo: o estado do Mato Grosso}

A definição do estado do Mato Grosso como objeto de estudo empírico, levou em conta dois aspectos. O primeiro aspecto diz respeito às características do contexto estadual de implementação. Nesse caso, o estudo Trajetórias de Implementação de mudanças no Ensino Médio nos estados brasileiros: impactos da Lei 13.415/2017 (LOTTA, BAUER, ROJAS e JOBIM, 2019a) permite situar a implementação da reforma realizada no estado do Mato Grosso no grupo de estados brasileiros com menos experiências prévias de mudanças no Ensino Médio. Nesse grupo, os estados apresentam iniciativas prévias geralmente induzidas pelo Governo Federal e, seguindo a mesma tendência, são impactados pela nova reforma de maneira proporcional aos investimentos feitos nas mudanças, bem como na adesão que apresentam aos incentivos federais (LOTTA, BAUER, ROJAS e JOBIM, 2019, p.18). Fazem parte desse grupo 12 estados, o que significa que o estado de Mato Grosso tem características comuns com cerca da metade das realidades estaduais de implementação da reforma do Ensino Médio.

O segundo aspecto que justifica a escolha do desse estado se relaciona com a limitada quantidade de estudos que contemplam a Região Centro Oeste e, dentro 
dela, o estado do Mato Grosso. Esse é um dos estados que apresenta os maiores desafios quando se consideram seus resultados educacionais visa a vis os outros estados da mesma Região. Segundo dados da Prova Brasil 2017, a proporção de alunos do $5^{\circ}$ ano com aprendizado adequado em português representa 54\% no MT contra $67 \%$ no DF, $72 \%$ em GO e $62 \%$ no MS. Com relação à matemática, o MT também apresenta percentuais inferiores aos demais estados da Região: 40\% dos alunos com aprendizado adequado no MT, enquanto o DF apresenta 54\%, GO 63\% e MS 46\%. Esse quadro se agrava quando avançamos para a etapa final do Ensino Médio. Em português, o estado apresenta um percentual de estudantes com aprendizado considerado adequado de $30 \%$, o que contrasta com o percentual de $36 \%$ do DF, $45 \%$ do GO e 40\% do MS. Em matemática esses índices diminuem drasticamente, já que apenas $12 \%$ dos alunos estão no nível adequado no MT, enquanto o DF, GO e MS, têm, respectivamente, $16 \%, 23 \%$ e $19 \%$ de estudantes nesse nível.

\section{Método e instrumento de coleta}

Ludke e André (1986) indicam que existem três tipos de coleta de dados utilizados em pesquisas qualitativas, sendo eles a observação, entrevista e pesquisa ou análise documental. Dessas três técnicas de pesquisa, só foi possível utilizar análise documental e entrevista. A intenção original de observar as interações dos atores no processo de implementação da reforma, mas a mesma foi impossibilitada pela quarentena imposta pela pandemia provocada pela COVID-19.

A entrevista é, segundo Godoy (2005), um dos métodos mais utilizados em pesquisas qualitativas. Marconi e Lakatos (1982, p.70) salientam que a entrevista tem como principal objetivo a "obtenção de informações do entrevistado sobre determinado assunto ou problema”. Marconi e Lakatos (1982) a definem como:

Um encontro entre duas pessoas, a fim de que uma delas obtenha informações a respeito de determinado assunto, mediante uma conversação de natureza profissional. É um procedimento utilizado na investigação social para coleta de dados ou para ajudar no diagnóstico ou no tratamento de um problema social. (MARCONI E LAKATOS, 1982, p. 70) 
Também com as entrevistas é possível obter, por meio das falas dos atores, dados objetivos e subjetivos. Enquanto os dados objetivos podem ser obtidos por outras fontes, os subjetivos são obtidos por meio de comunicação, pois estão relacionados aos valores, atitudes e opiniões (MINAYO, 2003). Considerando o tipo de pesquisa e seus objetivos, a realização de entrevistas possibilitou captar, além de dados objetivos, valores e anseios, dados subjetivos que não poderiam ser captados apenas na análise documental. Foi realizada também uma análise dos documentos nacionais e estaduais da reforma, além da revisão de literatura para a construção do referencial teórico, e da verificação de indicadores educacionais do estado do Mato Grosso para contextualização da pesquisa.

As entrevistas foram realizadas com três atores do alto e médio escalão da Secretaria Estadual de Educação do Estado de Mato Grosso (SEE-MT) que atuam na Coordenadoria de desenvolvimento do Ensino Médio (CEE). O primeiro entrevistado atua na equipe ProBNCC, que é o programa de apoio para a implementação da BNCC, na área das ciências da Natureza e suas tecnologias e compõe o Comitê de Acompanhamento da Implementação do Novo Ensino Médio no estado. O segundo entrevistado faz parte da equipe ProBNCC na área de linguagens e suas tecnologias. O terceiro entrevistado atua na área pedagógica da coordenadoria e compõe o Comitê.

As entrevistas foram realizadas individualmente, pois segundo Oliveira et al (2010, p. 43) "possibilita ao entrevistado, de forma mais personalizada, descrever fatos e narrativas do cotidiano social". Inicialmente as entrevistas ocorreriam presencialmente, porém, em virtude da pandemia causada pelo COVID-19 e da necessidade de isolamento social, os encontros foram realizados remotamente via ferramentas digitais: Google Meets, Zoom e Microsoft Teams. Os acordos realizados anteriormente garantiram que os atores entrevistados reservassem um período propício em suas agendas, evitando interferências externas e que os encontros fossem realizados em ambientes adequados para o sigilo das informações e melhor captação do áudio.

Com relação ao tipo de perguntas, Oliveira et al (2010, p. 45) sinalizam que as entrevistas podem ser de três tipos: estruturada, não estruturada ou aberta e semiestruturada. 
Na entrevista estruturada existe um modelo padronizado a ser seguido pelo entrevistador, com perguntas previamente estabelecidas. Nesse tipo de entrevista o entrevistador não pode realizar adaptações nas perguntas, mudar a ordem ou realizar qualquer alteração, assim como seus resultados tendem a ser uniformes. Segundo Gil (2005) esse tipo de entrevista possibilita o tratamento quantitativo dos dados, pois as respostas são padronizadas, e pode ser aplicada a um grande número de atores. Como benefícios, esse tipo de entrevista propicia a análise estatística dos dados, a maior rapidez na aplicação e uma preparação menor do entrevistador. Entretanto, esse tipo de entrevista não propicia uma análise mais profunda dos dados ou inserção de novas perguntas durante sua realização. (SZYMANSKI, 2004).

Na entrevista não estruturada ou aberta as informações são captadas via discurso livre do entrevistado. Neste tipo de pesquisa o ator fica livre para se expressar sem receios e cabe ao entrevistador interpretar as falas e gestos, exigindo habilidades de observação verbal e atitudinal (CHIZZOTTI, 1998).

A entrevista semiestruturada, segundo Oliveira et al (2010, p. 46), "parte de um roteiro pré-estabelecido, mas, na sua aplicação, o entrevistado pode acrescentar novas perguntas, conforme o teor da narrativa do entrevistado."

As entrevistas realizadas na pesquisa tiveram por base um roteiro semiestruturado (anexo 1) que permitiu realizar adequações ao longo de sua aplicação. Trivinos (1987) sinaliza ainda que o modelo semiestruturado é flexível e depende das circunstâncias que envolvem o tema em estudo, podendo haver perguntas abertas e fechadas. Neste modelo, segundo o autor, o entrevistado se torna coparticipante na estruturação da pesquisa. A realização de uma entrevista semiestruturada permitiu que uma mesma lógica fosse utilizada em todos os encontros, mas que a narrativa dos entrevistados fosse aprofundada em certos momentos, considerando sua maior participação ou acesso a questões específicas da reforma do Ensino Médio. Considerando os diferentes perfis e contribuições dos atores envolvidos na pesquisa, algumas perguntas tiveram um maior aprofundamento, assim como, conforme informações foram trazidas espontaneamente, algumas perguntas do roteiro não precisaram ser feitas. 
O roteiro foi elaborado a partir dos estudos de Lotta, Bauer, Rojas e Jobim, (2020), contemplando os seguintes documentos e materiais de referência do Novo Ensino Médio:

- o Portal do Novo Ensino Médio;

- o Guia de Implementação do Novo Ensino Médio;

- a Portaria 649/2018 que institui o Programa de Apoio ao Novo Ensino Médio, o Documento Orientador que a subsidia;

- a Portaria 1.024/2018 que institui Programa Dinheiro Direto na Escola às unidades escolares pertencentes às Secretarias participantes do Programa de Apoio ao Novo Ensino Médio;

- a Resolução MEC n 21/ 2018 que destina recursos financeiros, nos moldes operacionais e regulamentares do Programa Dinheiro Direto na Escola;

- Programa de Apoio à Implementação da Base Nacional Comum Curricular - ProBNCC;

- Portaria 1.023/2018 que estabelece diretrizes, parâmetros e critérios para a realização de avaliação de impacto do Programa de Fomento às Escolas de Ensino Médio em Tempo Integral - EMTI e seleção de novas unidades escolares para o Programa.

Com um total de 40 perguntas, o roteiro está divido em 6 grandes dimensões: Aquecimento e percepções iniciais sobre o tema; Informações sobre a rede; Prioridades e planejamento para a implementação da Reforma; Relações de governança interna; Implementação da Reforma do Ensino Médio; Relações de governança externa. Ludke e André (1986) sinalizam para a importância de o roteiro seguir uma ordem lógica, iniciando pelos temas mais simples até os mais complexos. Esse formato evita que questões complexas sejam colocadas prematuramente, assim como evita interferências na entrevista.

A primeira dimensão, aquecimento e percepções iniciais sobre o tema, é composta por perguntas relativas às expectativas dos entrevistados com a chegada da reforma e sobre como avaliam a implementação no estado. A segunda dimensão, informações sobre a rede, tem como objetivo entender o contexto da rede, considerando seu histórico antes da reforma. A terceira dimensão, prioridades e 
planejamento para a implementação da reforma, tem como objetivo identificar como a reforma chegou à secretaria, considerando canais de comunicação e pessoas envolvidas, quais são as ações prioritárias em desenvolvimento na rede e quais documentos ou políticas estão orientando a implementação da reforma. Considerando que as mudanças introduzidas pelo Novo Ensino Médio parecem ser grandes e significativas para as Secretarias Estaduais de Educação, a proposta da quarta dimensão, relações de governança interna, busca entender como a Secretaria está se organizando internamente para a implementação dessa política. A quinta dimensão, implementação da reforma, se pauta na identificação das ações de mudança que estão sendo implementadas pelo estado no Ensino Médio, quando a reforma começa a vigorar, as normativas criadas e como a rede estadual está se articulando com a sociedade nesse processo. A sexta e última dimensão, relações de governança externa, investiga a interação da secretaria com outros atores, órgãos e instituições para a implementação da reforma.

As entrevistas tiveram uma duração média de uma hora e meia e, ao final, foi proposta ao entrevistado uma pergunta livre para que ele pudesse apresentar algum novo elemento ou resgatar alguma informação dada anteriormente. Durante os encontros foi estabelecida uma interação amigável e dialógica com os entrevistados. As entrevistas realizadas foram gravadas e transcritas.

As dimensões da entrevista possibilitaram o levantamento de dados que conversam diretamente com os conceitos que referenciam a pesquisa: o incrementalismo, ao identificar os passos dados pela secretaria para a implementação da reforma e as mudanças geradas no modelo em vigor na rede estadual de ensino; as relações entre camadas federativas e níveis burocráticos, ao identificar a complexidade de implementação da política e como a mesma pode ou não ser alterada nos diferentes espaços e nas diferentes interações entre atores políticos e burocráticos; o contexto da implementação da política, ao identificar os graus de conflito e de ambiguidade que fazem parte do cenário da rede estudada e; as relações estabelecidas com o terceiro setor, ao identificar as parcerias não estatais que apoiam o processo de implementação da política no estado. 


\section{O Ensino Médio e as Políticas Educacionais}

O Ensino Médio é uma etapa da educação básica que vem passando por mudanças e definições importantes. Com a universalização do Ensino Fundamental, e com a definição da obrigatoriedade escolar dos 4 aos 17 anos de idade, o Ensino Médio passou a representar uma etapa da escolaridade na qual as trajetórias educacionais e sociais são definidas, constituindo-se em um campo de disputas no qual agem diferentes grupos de atores estatais e não estatais.

Para melhor compreender esse campo, esse capítulo está organizado em duas seções. A primeira aborda os principais marcos na trajetória das recentes políticas públicas para o Ensino Médio e seus principais debates. A segunda seção apresenta o contexto de implementação da reforma, considerando que sua chegada potencializou os debates e tensões nas discussões que já permeavam a trajetória deste local do Ensino Médio.

\section{1 - O Ensino Médio e as Políticas Educacionais: contextualização}

O Ensino Médio se configura como a finalização de um ciclo, em um momento de intensas modificações na vida do educando. Historicamente, o Ensino Médio foi objeto de diferentes olhares e concepções, e de políticas que enfatizaram ora a preparação para o mundo do trabalho ora a continuidade da vida escolar, conforme evidenciado por Oliveira (2019).

Ao voltar-se a atenção para o Ensino Médio, especificamente quando se pensa sobre a sua função social, ainda coloca-se em discussão a possibilidade de conjugar-se, nesse nível de ensino, a preparação para o trabalho e a formação para a continuidade dos estudos (OLIVEIRA, 2009, página 53).

Oliveira (2009) reflete sobre a necessidade de uma formação no Ensino Médio que considere a integralidade dos sujeitos e promova uma formação que não se resuma aos interesses do mercado de trabalho: 
Destacar a importância da articulação entre a formação geral e a formação profissional ainda se coloca como pedagógica e politicamente importante, uma vez que deve haver e vem existindo uma contínua e ininterrupta preocupação por parte daqueles que pesquisam na área de Trabalho e Educação e/ou Ensino Médio de reafirmar o quanto o processo de formação profissional não pode resumir-se apenas à apropriação de saberes práticos e úteis ao mercado de trabalho. Cada vez mais, a luta política por um Ensino Médio que objetive a formação "integral" dos educandos impõe-se como necessária e consequente. (OLIVEIRA, 2009, página $53)$.

Para o autor, a história do Ensino Médio se confunde com o próprio debate sobre sua identidade, que caracteriza a articulação entre a formação geral e a formação técnica como uma dualidade histórica.

Autores que se colocam numa perspectiva gramsciana, como Frigotto et al. (2005, p. 11), sinalizam para a expectativa social de superação dessa dualidade, pela via da promoção de uma formação unitária, politécnica, que "articule a cultura, conhecimento tecnológico e trabalho como direito de todos e condição da cidadania e democracia efetivas." Os autores elaboram uma proposta para o Ensino Médio que contempla essas duas formações, de maneira integrada e sintetizam essa questão colocando o Ensino Médio enquanto um direito social e subjetivo vinculado a todas as esferas e dimensões da vida dos sujeitos.

Em linha com os dados sobre o Ensino Fundamental e médio apresentados na introdução, está a fala de Oliveira (2009) quando reflete sobre o papel do Estado na implementação de políticas que superem os desafios postos à essa etapa da educação básica:

A forma como o Estado vem se responsabilizando pelo Ensino Médio, tanto no que diz respeito à concepção quanto ao financiamento, são obstáculos à efetivação de um projeto educativo no qual seja garantido não só o acesso aos saberes indispensáveis à formação técnica stricto sensu, mas também à apropriação de conhecimentos e à vivência de práticas que contribuam para a atuação na sociedade. (OLIVEIRA, 2009, página 56).

Como mostram os dados apresentados na Introdução desta pesquisa, esta reflexão, divulgada em artigo publicado há quase uma década, ainda é pertinente.

A realidade do Ensino Médio foi incorporada no longo debate sobre o modelo de educação a ser adotado nessa etapa final da Educação Básica. O debate 
envolve, por um lado, os que defendem a promoção de uma "leitura do mundo", que fomente a formação de cidadãos críticos e atuantes em uma sociedade passível de mudanças, conforme apontado por Zibas (ZIBAS, 2005, página 25):

Torna-se fundamental que a escola ensine a "leitura desse mundo", ou, em outras palavras, que desenvolva a cidadania democrática, aqui entendida como a compreensão histórica das relações estruturantes do mundo econômico e social, de forma que a sociedade seja percebida como passível de ser transformada.

Por outro lado, o debate conta com a participação de autores que focalizam o direito de os alunos aprenderem um certo conjunto de conhecimentos, enquanto frequentam as mesmas séries, seja no Ensino Fundamental, seja no Ensino Médio, em qualquer lugar do Brasil. Este é tido como um passo fundamental para o desenho de políticas públicas educacionais mais eficientes, para a redução das desigualdades educacionais, para a avaliação mais precisa do desenvolvimento do ensino, para o planejamento pedagógico, para a formação dos professores, entre outras dimensões (ANUARIO, 2018).

Esses históricos conflitos envolvendo o Ensino Médio foram recentemente atualizados e potencializados por uma mudança externa aos estados imposta pelo Governo Federal, como revelam as análises da política de Ensino Médio mais recentes (LOTTA ET AL., 2019). Para pontuar esses conflitos em uma perspectiva longitudinal, abordamos as políticas para o Ensino Médio tendo como marco a década de 1990, contexto da redemocratização do país e período no qual houve um processo inédito de expansão do Ensino Médio (OLIVEIRA, 2007) e também a luta em torno do significado desse nível de ensino que ganhou nova intensidade (ZIBAS, 2005). ${ }^{12}$

O projeto para a promulgação de uma nova Lei de Diretrizes e Bases da Educação Nacional - LDB se iniciou no final de 1988 e mobilizou parlamentares e todo o campo educacional organizado, por meio de eventos como a Associação Nacional de Educação (ANDE), a Associação Nacional de Docentes do Ensino Superior (ANDES), a Associação Nacional de Pesquisa e Pós-Graduação em

\footnotetext{
${ }^{12}$ Segundo Oliveira (2007), na década de 1990, é possível notar uma ampliação em mais de duas vezes do número de matrículas, saltando de um pouco menos de dois milhões em 1975 para mais de nove milhões em 2005.
} 
Educação (ANPed), a Confederação Nacional dos trabalhadores da Educação (CNTE), o Conselho Nacional dos Secretários Estaduais de Educação (CONSED), a União Nacional dos Dirigentes Municipais de Educação (UNDIME) e a União Brasileira dos estudantes Secundaristas (UBES). A articulação envolveu também a participação da sociedade civil por meio de audiências públicas, seminários e outros meios, se configurando em clima de democracia e cidadania que culminou na elaboração de um projeto de lei aprovado pela Comissão da Educação no Senado no ano de 1990. Porém, um outro projeto, focado na gestão administrativa e nas políticas relativas ao financiamento da educação foi elaborado por senadores e técnicos em 1993 (BORBA, 2011). Nessa disputa, a segunda proposta foi vencedora e, em 20 de dezembro de 1996, foi aprovada a Lei n. 9.394/96, que estabelece as diretrizes e bases da educação nacional. Nesta lei, o ensino secundário foi renomeado como Ensino Médio, sendo destinado aos jovens de 15 a 17 anos com conclusão do Ensino Fundamental, não sendo obrigatório. Na ocasião, foram atribuídas as seguintes finalidades:

I - a consolidação e o aprofundamento dos conhecimentos adquiridos no Ensino Fundamental, possibilitando o prosseguimento de estudos;

II - a preparação básica para o trabalho e a cidadania do educando, para continuar aprendendo, de modo a ser capaz de se adaptar com flexibilidade a novas condições de ocupação ou aperfeiçoamento posteriores;

III - o aprimoramento do educando como pessoa humana, incluindo a formação ética e o desenvolvimento da autonomia intelectual e do pensamento crítico;

IV - a compreensão dos fundamentos científico-tecnológicos dos processos produtivos, relacionando a teoria com a prática, no ensino de cada disciplina. (LDB, 1996)

A lei estabeleceu também uma estrutura curricular única em nível nacional, tendo como fundamento a oferta de uma formação geral e polivalente para a preparação para a vida (MELO \& DUARTE, 2011). Com relação às disputas em torno dos dois projetos de lei, ressalta-se que as tensões e lutas travadas no campo de educação são históricas e que seus resultados influenciam tanto a formulação das políticas públicas educacionais como seu contexto de implementação. Segundo Santos e Diógenes (2017, pg.9): 
Os sucessivos movimentos de reformas da educação brasileira, desde a Reforma Capanema - implantada com a Revolução de 1930 - até a que foi deflagrada nos anos finais do século XX, demonstram que a educação é campo de luta privilegiado e, dependendo das forças sociais dominantes, as tendências da política educacional assumem essas ou aquelas características.

Em continuidade às políticas direcionadas à etapa educacional analisada, em 1997 inicia-se a chamada reforma do Ensino Médio e da educação profissional. Essa reforma tinha como propósito a oferta do ensino técnico em separado da formação regular. Em dissonância ao estabelecido na Lei n. 9.394/96, na qual a educação profissional foi entendida como uma modalidade do Ensino Médio, a reforma de 1997 possibilitava a sua articulação com o ensino regular, mas sem se constituir em parte integrante. Entre 2004 e 2007, período no qual o país foi governado por Lula, houve o lançamento do decreto n. 5.154/04. O decreto regulamenta o $\S 2^{\circ}$ do art. 36 e os arts. 39 a 41 da Lei $n^{\circ} 9.394$, de 20 de dezembro de 1996, que estabelece as diretrizes e bases da educação nacional, readmitindo a integração das escolas de Ensino Médio com a educação integral. Entretanto a opção pela integração ficava a critério das próprias escolas, o que, segundo Melo \& Duarte (2011), resultou em experiências limitadas em termos quantitativos e qualitativos. A educação profissional foi oferecida de maneira secundária nas redes estaduais e a integração entre as modalidades foi realizada de maneira pontual e, muito frequentemente, por meio do estabelecimento de parcerias com o setor privado lucrativo e não lucrativo ou de projetos pilotos.

Nos anos 2000, surge a iniciativa do Governo Federal financiada pelo Banco Interamericano de Desenvolvimento (BID), o programa federal Melhoria $e$ Expansão do Ensino Médio ${ }^{13}$ também conhecido como projeto Escola Jovem, que tinha como proposta a melhoria da qualidade do ensino e ampliação de sua oferta em escala nacional para maior equidade social. Contava para isso com a

13 O programa federal Melhoria e Expansão do Ensino Médio - PROMERD também chamado Projeto Escola Jovem, é uma iniciativa da Secretaria de Ensino Médio Tecnológico do Ministério da Educação (MEC) com o apoio do Banco Interamericano de Desenvolvimento (BID) com o objetivo de melhoria da qualidade e da eficiência do Ensino Médio, garantindo o maior acesso e contribuindo para o desenvolvimento econômico e social do País. O programa foi criado em 1997 e fornece recursos relacionados à execução de projetos de ampliação e construção de escolas, capacitação de docentes e gestores educacionais, equipamentos para bibliotecas, laboratórios e adaptações para facilitar o acesso de portadores de necessidades especiais. (MENEZES E SANTOS, 2001) 
implementação da reforma curricular e estrutural e com a expansão do atendimento (MELO \& DUARTE, 2011).

Em 2007 o país viveu o segundo mandato do governo Lula, que manteve os investimentos na melhoria do Ensino Médio e criou novas normas e programas para a integração do ensino regular com o profissional. Com foco nesse período, Melo \& Duarte (2011) destacam cinco aspectos relacionados às políticas educacionais então criadas. O primeiro está relacionado ao decreto n. 6.095/2007 e à aprovação da Lei n. 11.892/2008 que tiveram como objetivo a constituição dos Institutos Federais de Educação, Ciência e Tecnologia (IF) e a reorganização da Rede Federal de Educação Tecnológica, com importantes reflexos para a reforma do Ensino Médio e profissional. O segundo aspecto está relacionado à Emenda Constitucional n. 59 que versa sobre a educação básica obrigatória e gratuita de 4 a 17 anos de idade, aspecto importante mesmo que essa definição etária não tenha se configurado até hoje como um mecanismo de incentivo à universalização do Ensino Médio. O terceiro aspecto faz menção à instituição do Programa Ensino Médio Inovador. Tendo sua implementação iniciada em 2009, o Programa se caracterizou como um incentivo às redes estaduais de educação para elaborarem iniciativas inovadoras para esta etapa da educação com o apoio técnico e financeiro do Governo Federal e em parceria com o Sistema $\mathrm{S}^{14}$. Este aspecto tinha como intencionalidade estimular as redes estaduais a elaborarem novas ações e também a diversificarem seus currículos a partir dos eixos ciência, tecnologia, cultura e trabalho. O quarto aspecto se relaciona à reelaboração do Exame Nacional do Ensino Médio (Enem). Em 2009 e 2010, o exame passou por um processo de reelaboração que culminou em sua utilização como vestibular unificado para as universidades federais e teve reflexos nos debates curriculares em torno da Base Nacional Comum Curricular (BNCC). O quinto e último aspecto trata do protagonismo juvenil no governo Lula, caracterizando-o como um período de grandes investimentos em políticas

\footnotetext{
${ }^{14}$ Sistema S é termo utilizado para definição do conjunto de organizações das entidades corporativas voltadas para o treinamento profissional, assistência social, consultoria, pesquisa e assistência técnica, que possuem seu nome iniciado com a letra S, partilham de raízes comuns e características organizacionais similares. Fazem parte do sistema S: Serviço Nacional de Aprendizagem Industrial (Senai); Serviço Social do Comércio (Sesc); Serviço Social da Indústria (Sesi); e Serviço Nacional de Aprendizagem do Comércio (Senac). Existem ainda os seguintes: Serviço Nacional de Aprendizagem Rural (Senar); Serviço Nacional de Aprendizagem do Cooperativismo (Sescoop); e Serviço Social de Transporte (Sest)(AGÊNCIA SENADO, 2020).
} 
destinadas à juventude e com continuidade no governo Dilma. Segundo Melo \& Duarte (2011):

Com efeito, a partir de 2005, inicia-se o processo de institucionalização das Políticas para a Juventude no Brasil, cuja discussão havia sido iniciada em 2003. Nesse processo, destacam-se a criação da Secretaria e do Conselho Nacional de Juventude (2005); do Programa Nacional de Inclusão de Jovens: Educação, Qualificação e Ação Comunitária (PROJOVEM) (2006); do Programa Universidade para Todos (PROUNI) (2005); do Programa de Apoio a Planos de Reestruturação e Expansão das Universidades Federais (REUNI) (2007); os Pontos de Cultura e as Praças da Juventude, entre outros que, apesar de não serem exclusivos de juventude, atendem, mormente, os jovens brasileiros pertencentes às camadas populares, em situação de defasagem escolar, desemprego e vulnerabilidade social (MELO \& DUARTE, 2011, pg. 237).

Melo \& Duarte (2011) indicam que, nesse período, houve iniciativas com foco na melhoria do Ensino Médio, tais como a transferência da responsabilidade para os estados pela sua oferta; a alteração de sua estrutura; a introdução de um currículo por competências; a avaliação em larga escala, dentre outras. Porém, apesar dos avanços identificados, alguns grandes desafios ainda se mantém, tais como a sua universalização, a garantia da qualidade e de identidade própria dentro do sistema, além da articulação entre as dimensões formativas referentes à escola unitária e politécnica.

Em 2011 surge o Programa Nacional de Acesso ao Ensino Técnico e Emprego - PRONATEC, que possui como objetivo a concessão de bolsas de estudos aos estudantes e reacende as discussões sobre o Ensino Médio integrado, considerando as reflexões sobre a identidade desta etapa da educação. (MESQUITA \& LELIS, 2015).

Em 2014 surge o novo Plano Nacional de Educação (PNE), lei ordinária que determina as diretrizes, metas e estratégias para a política educacional e que possui como finalidade o direcionamento de esforços e investimentos para a melhoria da qualidade da educação no país. O PNE estabeleceu, em sua versão mais recente para o decênio 2014/2024, metas para o Ensino Médio. Do conjunto de 20 metas que versam sobre as principais questões educacionais brasileiras, tais como as relativas ao financiamento da educação, gestão democrática, oferta de educação integral e valorização do professor, as metas 3, 10 e 11 tratam do Ensino Médio e possuem como objetivo, respectivamente, "Universalizar, até 2016, o atendimento escolar para toda a população de 15 a 17 anos e elevar, até o final do período de 
vigência deste PNE, a taxa líquida de matrículas no Ensino Médio para 85\%.”, “Oferecer, no mínimo, 25\% (vinte e cinco por cento) das matrículas de educação de jovens e adultos, nos ensinos fundamental e médio, na forma integrada à educação profissional” e "Triplicar as matrículas da educação profissional técnica de nível médio, assegurando a qualidade da oferta e pelo menos $50 \%$ (cinquenta por cento) da expansão no segmento público.”

Neste contexto, a criação de uma Base Nacional Comum Curricular (BNCC) e a elaboração de uma nova proposta de estruturação do Ensino Médio surgem como uma possível resposta do governo a essas questões. Entretanto esse cenário precisa ser analisado reconhecendo as diferentes forças e espectros ideológicos e político-partidários que têm participado desse movimento de mudanças no sistema educacional.

As políticas dirigidas atualmente ao Ensino Médio, notadamente a reforma e a BNCC, caracterizam-se como arranjos altamente complexos, que envolvem uma multiplicidade de organizações no processo contínuo de produção dessa política, além de se tratar de duas políticas nacionais normatizadas pelo Governo Federal que também adota estratégias e incentivos visando à adesão dos entes subnacionais. Além disso, as duas políticas envolvem intensa interação entre atores estatais e não estatais.

As relações entre formação profissional e formação geral no Ensino Médio se manifestaram no Brasil na forma que estudiosos conceituam como uma dualidade educacional presente nas diferentes reformas dessa etapa de ensino. Por dualidade educacional os autores estão se referindo a um sistema dual de educação, que visa a atender os interesses econômicos e simbólicos dos diferentes grupos sociais no interior da sociedade, distribuindo-os seja para o ensino superior, seja para o mundo do trabalho.

\section{2 - A medida provisória ${ }^{\circ}$ 746, de 2016: A Reforma do Ensino Médio}

A reforma do Ensino Médio foi promulgada em setembro de 2016 via medida provisória pelo recém-empossado presidente Michel Temer e possui como principais pontos de mudança: a diversificação do currículo escolar, incluindo o 
ensino técnico como uma das opções de formação, e o financiamento do Ensino Médio de tempo integral. Esta etapa da educação apresenta grandes problemas, dentre eles as altas taxas de abandono e um currículo direcionado à preparação para o Exame Nacional do Ensino Médio - Enem, se tornando o foco de discussões e reflexões.

O fato de a reforma ter sido instituída via medida provisória gerou questionamentos na sociedade, evidenciados nas mídias e em outros meios, mobilizando um amplo debate que ultrapassou a comunidade escolar. Apesar de parte dos elementos presentes na reforma serem consensuais entre diversos atores da sociedade e terem sido objeto de amplos debates na última década, o processo decisório via a promulgação de uma medida provisória gerou questionamentos e posicionamentos divergentes, se tornando um dos principais pontos de embate. Enquanto diversos setores acadêmicos e não acadêmicos consideravam a medida autoritária, o governo defendia a medida provisória como uma estratégia para resolução do projeto de lei (PL6840/2013) que fazia alguns anos tramitava no Congresso Nacional (SCHWARTZMAN, 2018).

No contexto desse embate, o Observatório do Ensino Médio da Universidade Federal do Paraná, em manifesto publicado em sua página na internet no dia 22 de setembro de 2016, realizou críticas ao processo que, de alguma forma, sintetizam as críticas que circulavam no âmbito social mais amplo:

O Governo Federal anunciou hoje (22/09/2016), por meio de Medida Provisória, uma reforma no Ensino Médio Brasileiro. Consideramos ilegítimo o uso da Medida Provisória para esse fim, o que se institui como forma absolutamente antidemocrática de promover mudanças no campo da educação. O Ensino Médio tem sido alvo de preocupações por parte de gestores, professores, pesquisadores e várias entidades da área, o que, por si só, justifica a necessidade de uma ampla discussão na sociedade brasileira, desde que considere os interesses e necessidades de todos os envolvidos, em particular de estudantes.

Em contrapartida, o MEC, em seu canal de comunicação com a sociedade, a fim de responder questionamentos sobre a reforma, sinaliza que a Medida Provisória é fruto de um amplo debate da sociedade e que seguiu as exigências previstas na Constituição Federal. A nota de esclarecimento faz menção também 
aos eventos que, segundo o MEC, teriam propiciado a discussão sobre o Ensino

Médio e permitido ao governo editar a Medida Provisória:

A edição da Medida Provisória (MP) seguiu rigorosamente as exigências previstas na Constituição Federal. Em primeiro lugar, em decorrência da urgência do problema desse nível de ensino no país, dados do IDEB recém-divulgados mostram uma realidade trágica no Ensino Médio e retratam a urgência da reforma. Em segundo lugar, em consequência da relevância do tema que se apresenta na medida em que o fracasso do Ensino Médio brasileiro é um dado da realidade, como demonstram os resultados das avaliações nacionais e internacionais. As propostas da MP são fruto do amplo debate acumulado no país nas últimas décadas, o que permitiu ao governo acelerar a reforma. - 1998: Grande debate e aprovação das diretrizes do EM de acordo com a nova legislação da LDB de 1996; - 2002: Seminário Nacional sobre reforma do Ensino Médio; - 2007: FUNDEB com a promessa de garantir a universalização do EM; - 2007: MEC lança o Plano de Ações Articuladas; - 2009: Novo ENEM; - 2010: Ensino Médio Inovador; - 2010: CONSED cria o Grupo de Trabalho da Reforma do Ensino Médio; - 2012: Diretrizes Curriculares Nacionais para o Ensino Médio aprovadas pelo CNE; 2013: Projeto de Lei (PL6840/2013); - 2014: Plano Nacional da Educação (PNE). Meta 3.1: "Institucionalizar programa nacional de renovação do Ensino Médio, a fim de incentivar práticas pedagógicas com abordagens interdisciplinares estruturadas pela relação entre teoria e prática, por meio de currículos escolares que organizem, de maneira flexível e diversificada, conteúdos obrigatórios e eletivos articulados..." Portanto, a reforma do Ensino Médio está sendo discutida há anos. Em 2013, foi apresentado o PL 6840 na Câmara dos Deputados, que também foi amplamente debatido. No entanto, a tramitação do PL no Congresso ficou aquém da urgência da reforma. Vale destacar que diversos projetos e reformas relevantes e urgentes para o país foram editados por Medida Provisória e se tornaram Lei, como por exemplo o Brasil Carinhoso, Mais Médicos, o PNAIC, PROUNI e Royalties do Petróleo para a Educação. (Site do MEC - O Novo Ensino Médio, 2018)

A Medida Provisória n 746 de 2016, conhecida como Reforma do Ensino Médio, é de autoria da Presidência da República e altera a Lei de Diretrizes e Bases da Educação Nacional - LDB, a lei n 9.394 de 1996 e também a lei que regulamenta o Fundo de Manutenção e Desenvolvimento da Educação Básica e de Valorização dos profissionais da Educação - Fundeb (lei nº11.494 de 2007). Após o período de tramitação, passando pela apreciação das casas do Congresso Nacional, a MP nº746 de 2016 foi transformada na Lei ${ }^{\circ} 13.415$ de 16/02/2017.

A reforma promove:

alterações na estrutura do Ensino Médio, última etapa da educação básica, por meio da criação da Política de Fomento à Implementação de Escolas de Ensino Médio em Tempo Integral. Amplia a carga horária mínima anual do Ensino Médio, 
progressivamente, para 1.400 horas. Determina que o ensino de língua portuguesa e matemática será obrigatório nos três anos do Ensino Médio. Restringe a obrigatoriedade do ensino da arte e da educação física à educação infantil e ao Ensino Fundamental, tornando-as facultativas no Ensino Médio. Torna obrigatório o ensino da língua inglesa a partir do sexto ano do Ensino Fundamental e nos currículos do Ensino Médio, facultando, neste, o oferecimento de outros idiomas, preferencialmente o espanhol. Permite que conteúdos cursados no Ensino Médio sejam aproveitados no ensino superior. O currículo do Ensino Médio será composto pela Base Nacional Comum Curricular - BNCC e por itinerários formativos específicos definidos em cada sistema de ensino e com ênfase nas áreas de linguagens, matemática, ciências da natureza, ciências humanas e formação técnica e profissional. Dá autonomia aos sistemas de ensino para definir a organização das áreas de conhecimento, as competências, habilidades e expectativas de aprendizagem definidas na BNCC. (Congresso Nacional, texto da ementa da Medida Provisória nº 746, de 2016)

A reforma faz referência à BNCC do Ensino Médio, documento homologado em dezembro de 2018 e que define as aprendizagens essenciais para essa etapa da educação, conforme explicitado em documentos oficiais:

A Base Nacional Comum Curricular (BNCC) é um documento de caráter normativo que define o conjunto orgânico e progressivo de aprendizagens essenciais que todos os alunos devem desenvolver ao longo das etapas e modalidades da Educação Básica, de modo a que tenham assegurados seus direitos de aprendizagem e desenvolvimento, em conformidade com o que preceitua o Plano Nacional de Educação (PNE). (Documento homologado pela Portaria ${ }^{\circ}$ 1.570, publicada no D.O.U. de 21/12/2017, Seção 1, Pág. 146.)

A BNCC é a referência nacional para definição dos currículos da Educação Infantil, do Ensino Fundamental e do Ensino Médio, integrando a política nacional da Educação Básica a partir de um alinhamento com outras políticas e ações dos sistemas estaduais e municipais de ensino. Com relação à reforma do Ensino Médio, a $\mathrm{BNCC}$ define os direitos e objetivos de aprendizagem nas seguintes áreas de conhecimento: I - linguagens e suas tecnologias; II - matemática e suas tecnologias; III - ciências da natureza e suas tecnologias; IV - ciências humanas e sociais aplicadas.

A partir da reforma, o currículo do Ensino Médio passa a ser composto pela BNCC e por itinerários formativos, segundo definido pelo artigo 36 da lei $\mathrm{n}^{\mathrm{o}} 13.415$ de 2017:

O currículo do Ensino Médio será composto pela Base Nacional Comum Curricular e por itinerários formativos, que deverão ser organizados por meio da oferta de 
diferentes arranjos curriculares, conforme a relevância para o contexto local e a possibilidade dos sistemas de ensino, a saber: I - linguagens e suas tecnologias; II - matemática e suas tecnologias; III - ciências da natureza e suas tecnologias; IV - ciências humanas e sociais aplicadas; V - formação técnica e profissional. (Artigo 36 da lei $\mathrm{n}^{\mathrm{o}} 13.415$ de 2017)

O artigo 36 afirma que a definição da oferta dos itinerários formativos será realizada a partir das possibilidades de cada sistema de ensino e o dever das escolas de apoiar os alunos para a seleção do itinerário e de orientá-los no processo de escolha das áreas de conhecimento ou de atuação profissional.

A reforma do Ensino Médio e a BNCC também se articulam em torno da proposta de ampliação progressiva da carga horária. Essa proposta se coloca na perspectiva da implementação do Ensino Médio de tempo integral, articulado a currículos que considerem "a formação integral do aluno, de maneira a adotar um trabalho voltado para a construção de seu projeto de vida e para sua formação nos aspectos físicos, cognitivos e socioemocionais".

A reforma se configura em um marco na história das políticas voltadas ao Ensino Médio e desperta muitas discussões com relação ao seu processo de promulgação e às mudanças provocadas. Tais discussões se refletem em movimentos de resistência e apresentam preocupações importantes no que tange à potencialização de desigualdades, conforme será analisado na próxima seção.

\section{3 - A Reforma do Ensino Médio e seus desdobramentos na sociedade}

Conforme apresentado nas seções anteriores, a reforma chega em um contexto de investimentos públicos no Ensino Médio e também em um cenário de grandes discussões e tensões da sociedade sobre sua finalidade na formação dos jovens. Apesar de o governo apontar sua chegada enquanto continuidade dos investimentos nesta etapa da educação, muitas são as reflexões da sociedade acerca dos elementos que a constituem. Além das grandes controvérsias geradas pela maneira com a qual a medida surgiu, via medida provisória e sem participação da sociedade, como analisado nas seções anteriores, outras tensões e preocupações se dão em torno dos elementos que constituem essa política. 
Umas das tensões geradas pela reforma se relaciona com a carga horária mínima anual para o Ensino Médio. A lei n. 9.394/1996 dispõe que a carga horária mínima anual dos níveis fundamental e médio seria de oitocentas horas, distribuídas em pelo menos duzentos dias letivos. A lei 13.415/2017 estabelece que as redes de educação ampliem progressivamente para mil e quatrocentas horas sua carga horária. A lei promove a ampliação de 600 horas por ano, configurando um turno a mais por dia, o que seria o horário integral (MACIEL, 2019; LIMA \&MACIEL, 2018). Dois elementos da reforma levantam tensões, o primeiro é com relação à destinação de recursos que propiciem essas novas iniciativas nas escolas. Maciel (2019) aponta que a lei 13.415/17 não destina recursos que atendam à demanda de ampliação da carga horária, pois a ampliação, em consonância com o estabelecido na meta 6 do PNE, requer a implementação de estratégias intrínsecas, tais como investimentos na infraestrutura escolar e em atividades de acompanhamento pedagógico e multidisciplinar. Segundo o autor, a garantia da qualidade do ensino não está ligada apenas ao aumento da carga horária, mas também necessita de investimentos nesses outros aspectos ou os resultados podem ser contrários. Lima e Maciel (2018) discutem a mudança na carga horária, pois a lei que regulamenta a reforma estabelece uma carga horária máxima para a BNCC, limitando-a, de forma contrária ao discurso de ampliação da formação básica obrigatória. Na atual estrutura, a BNCC foi limitada ao máximo de 1.800 horas do total da carga horária da etapa, um número menor em relação às 2.400 horas estabelecidas anteriormente na LDB, se configurando em uma diminuição de 600 horas de formação básica em toda a etapa. Nessa perspectiva, as autoras salientam que a reforma promove uma ampliação da formação especializante, visto que a ampliação da carga horária proposta na reforma a beneficia em virtude da redução de horas dedicadas à formação básica com a BNCC.

Schwartzman (2018), por sua vez, sinaliza que a Lei estabelece um prazo de cinco anos para a mudança da carga horária para três mil horas e que aloca recursos federais para complementar os gastos com a implantação do tempo integral, porém não contempla o ensino noturno deste segmento. $\mathrm{O}$ autor ressalta a gravidade dessa questão, pois, em 2016, o ensino noturno foi o responsável por atender cerca de $23 \%$ dos alunos do ensino regular e mais de $60 \%$ dos alunos de cursos técnicos. 
Outro ponto de tensão analisado é a oferta da língua estrangeira. $\mathrm{O}$ artigo $3^{\circ}$ define que os currículos do Ensino Médio deverão incluir, obrigatoriamente, o estudo da língua inglesa e possibilita que outras línguas estrangeiras sejam oferecidas, em caráter optativo. Maciel (2019) analisa essa mudança, sinalizando que na LDB a escolha da língua estrangeira era de responsabilidade das escolas, sendo indicado preferencialmente o espanhol, e que isso pode agravar o cenário educacional à medida que existe uma carência de formação docente para o ensino de inglês em determinados locais e, principalmente, porque a língua espanhola tem grande centralidade no Brasil, visto que o mesmo faz fronteira com países da América do Sul, sendo a exigência do inglês uma iniciativa que estaria na contramão da realidade do país.

Os componentes obrigatórios do currículo do Ensino Médio também são analisados por Maciel (2019) na perceptiva das tensões que podem ser geradas na implementação da reforma. Ainda quando a proposta era uma medida provisória, houve a retirada da obrigatoriedade da educação física e da arte como componentes curriculares. Essa exclusão teve grande repercussão, levando a sua reincorporação na redação da proposta de lei, que retomou a obrigatoriedade desses componentes curriculares. Nos trâmites para a versão final da lei, surgiu uma nova definição sobre a oferta desses componentes, agora de maneira vaga e imprecisa, dando abertura para a não obrigatoriedade de oferta pelas redes de ensino. A oferta desses componentes surge com "estudos e práticas" e isso faz com que, segundo Maciel (2019), se perca a exigência legal, gerando um potencial cenário de prejuízos ao desenvolvimento físico e intelectual aos jovens que cursam essa etapa da Educação Básica.

Os itinerários formativos também possuem centralidade nessas discussões. Apesar de a reforma apresentar cinco itinerários, sua oferta ficará a critério das redes de ensino. A lei não define o número de itinerários formativos que cada ente federativo deve incluir, indicando a necessidade de que seja considerada sua relevância para o contexto local e as possibilidades dos sistemas de ensino. Ferreti (2018) alerta para as controvérsias em torno desta questão, pois no §12 do artigo 36 define-se que "as escolas deverão orientar os alunos no processo de escolha das áreas de conhecimento ou de atuação profissional previstas no caput". Maciel (2019) também aponta que não existe a suposta flexibilização curricular, visto que 
ao estudante não é possibilitada a oportunidade de experienciar outros itinerários, pois aquele que for definido no início da trajetória deverá ser seguido até o final.

A educação a distância ganha destaque na equação entre expansão de vagas e qualidade do ensino ofertado. A lei 13.415/17 possibilita aos sistemas de ensino firmarem convênios com instituições de educação a distância que possuam notório reconhecimento. A educação a distância também está prevista no PNE e possui como objetivo ampliar a oferta e facilitar o acesso à educação. Maciel (2019) ressalta a preocupação como o fato dessa modalidade de ensino vir a tornar-se um subterfugio do governo para elevar a oferta de matrículas e de vagas, sem garantia de qualidade. $\mathrm{O}$ autor ressalta ainda que, principalmente na Educação Básica, esta modalidade de ensino não é a mais adequada.

Os profissionais da Educação Básica são outro ponto de tensão no cenário desenhado pela reforma. A lei 13.415/17 em seu artigo 61, IV e V inclui duas novas categorias de profissionais da educação básica, sendo eles "profissionais com notório saber reconhecido pelos respectivos sistemas de ensino, para ministrar conteúdos de áreas afins à sua formação ou experiência profissional, atestados por titulação específica ou prática de ensino.;" e " profissionais graduados que tenham feito complementação pedagógica, conforme disposto pelo Conselho Nacional de Educação”. Maciel (2019) salienta que atualmente um dos maiores desafios na educação brasileira é a formação e qualificação docente, assim como sua má remuneração e a baixa atratividade profissional. O artigo 61, segundo o autor, potencializa esse desafio, visto que dispensa a formação e titulação do profissional que irá atuar nesta etapa, mesmo que essa atuação seja restrita ao quinto itinerário (formação técnico-profissional). Maciel (2019) ressalta ainda que a contratação de profissionais com notório saber vai na contramão ao exposto na meta 15 do PNE, no qual a formação específica de nível superior é requerida.

Por sua vez, a política de fomento à implementação de escolas de Ensino Médio em tempo integral é objeto de preocupação, principalmente no que tange à sustentabilidade dessas iniciativas nas redes estaduais de ensino. A política prevê o repasse de recursos do MEC aos entes federados e Distrito Federal por 10 anos, mas existe um histórico de descontinuidade de políticas e programas sociais antes do alcance dos objetivos previstos inicialmente (MACIEL, 2019). 
Lotta et al (2019) resumem da seguinte forma os aspectos chaves da lei $13415 / 17:$

- Formação Integral e Protagonismo do Estudante, que inclui iniciativas de desenvolvimento de projetos de vida; possibilidade de escolha dos estudantes; possibilidade de especialização em área do conhecimento; desenvolvimento de atividades de orientação e/ou tutoria.

- Inovações Curriculares e Novos Formatos de Ensino, que reúne iniciativas de currículo organizado por área de conhecimento; docente que trabalha por área de conhecimento; currículo organizado por competências e habilidades; currículo que integra disciplinas.

- Educação Profissional e Técnica, que inclui iniciativas de desenvolvimento de parcerias com setor produtivo nas escolas; integração do ensino técnico profissional ao Ensino Médio em único turno; existência de práticas que integram o mundo do trabalho.

A implementação da reforma se configura em tensões relativas à sua efetividade nas redes de ensino. Segundo estabelecido na lei que rege o Novo Ensino Médio, as redes devem estabelecer o cronograma de implementação no primeiro ano letivo seguinte à data de publicação da BNCC, ou seja, no ano de 2019, e devem iniciar a sua implementação a partir do segundo ano letivo subsequente à sua homologação, ou seja, a implementação da reforma tem previsão de início no presente ano de 2020. Aqui as tensões se acirram quando se considera a diversidade e peculiaridade de educação brasileira, o que se constitui em desafios para a implementação da reforma em todo o território nacional. Destacam-se ainda os desafios relativos à infraestrutura física dos espaços escolares e às carências no quadro de docentes (MACIEL, 2019). Além destes desafios históricos, em 2020 o cenário mundial se defronta com uma crise sanitária e social. No Brasil, em março de 2020 foi decretada pandemia devido ao vírus COVID-19, conhecido popularmente como coronavírus. No dia 20 do mesmo mês, o país decretou calamidade pública e tomou medidas emergenciais para o controle desta doença. Com o avanço do vírus, o aumento de casos no país vem crescendo a cada dia e isso impacta diretamente na educação. Desde março as redes estaduais e municipais, públicas e privadas, interromperam suas atividades. As rotinas administrativas e 
pedagógicas das secretarias de educação iniciaram um novo processo de funcionamento, estabelecendo um quadro de rodízio, home office ou recesso no seu quadro de funcionários. Para além dessas rotinas, as prioridades das secretarias se voltam para o combate aos efeitos da pandemia e para o desenho de estratégias para mitigação dos problemas e prejuízos sociais e pedagógicos.

Esta seção permite compreender que o Novo Ensino Médio não acontece em um vácuo institucional, ele chega em contextos estaduais onde várias ações já estão em curso e causa mudanças neste cenário. Além disso, reformas não são apenas concretas, materiais, elas carregam símbolos e sentidos que, ao serem anunciados, provocam novas mudanças. Isso se potencializa quando a reforma explicita um conjunto de conflitos entre atores de diferentes posições sociais que passam a se posicionar frente aos símbolos e sentidos anunciados.

\section{4 - A Reforma do Ensino Médio nos Estados Brasileiros: olhar para a implementação de uma política}

Segundo Corti (2019) reformas do Ensino Médio não são episódicas ou isoladas nas agendas governamentais brasileiras, mas sim algo constante. Para o autor, se considerarmos os desafios e a falência dos sistemas oficiais de ensino, o surgimento das reformas nas agendas governamentais se constitui em importante peça no jogo político.

Em particular, Lotta et al (2019) sinalizam para o número restrito de estudos sobre os resultados e impactos dessas reformas nos estados, e sustentam a necessidade de mais investigações que também considerem as ações prévias dos estados como parte constitutiva do contexto de implementação.

Neste sentido, considera-se que as mudanças no currículo do Ensino Médio e o fomento à educação de tempo integral já são questões presentes nas discussões promovidas por estados e municípios ao longo da última década. Muitos estados possuem histórico de ações e de mudanças no Ensino Médio e estas ações variam tanto em função das disparidades nas capacidades estatais políticas e técnicoadministrativas de implementação de políticas públicas, quanto em razão dos diferentes graus de incerteza e de conflito dos contextos de implementação. Isso faz 
com que a implementação da reforma do Ensino Médio tenha contornos diferentes e singulares em cada território. O estudo de Lotta e colegas (2019) denominado Trajetórias de Implementação de Mudanças no Ensino Médio nos Estados Brasileiros: impactos da Lei 13.415/2017 mostra as diferenças na abrangência, diversidade e tipos de iniciativas estatais dirigidas ao Ensino Médio nos últimos anos, e também os diferentes contextos de implementação conformados pela reforma.

Lotta e colegas (2019) sinalizam que os estados estão experimentando novas mudanças, testando experiências e que existe pouco investimento na construção de normas e regulamentações para a implementação da reforma do Ensino Médio. A pesquisa indica ainda que os estados aguardam definições do Governo Federal, para orientar a implementação. Neste contexto, as autoras sugerem que existem dois fatores essenciais para a compreensão das mudanças que aconteceram nos estados, sendo eles a indução federal e a disseminação de experiências. A ação federal compreende as políticas de incentivo e indução que, no caso da reforma do Ensino Médio, são o Ensino Médio Inovador (ProEMI) e o Ensino Médio e Tempo Integral - EMTI. Essas políticas, quando implementadas, acabam por induzir outras mudanças nas redes que, segundo as autoras, atuam quase como um efeito em cascata. Com relação ao processo de disseminação de experiências, destacam-se as estratégias para a troca de experiências entre os estados, que acabam por criar um isomorfismo institucional. Com relação a este fator, as autoras ressaltam o papel desempenhado pelo Consed e pelo MEC via a promoção de espaços de troca, intensas agendas de atividades e disseminação de experiências de referência.

Lotta et al (2019) concluem que havia processos de mudanças sendo desenvolvidos pelos estados que eram anteriores à chegada da reforma, mas que esses processos aconteciam de maneiras distintas: enquanto alguns estados possuíam uma agenda própria, outros vivenciavam experimentações via indução do Governo Federal e/ou de parcerias estabelecidas com o terceiro setor. As autoras mostram que a reforma do Ensino Médio gerou importantes mudanças no cenário educacional dos estados, servindo inclusive de mola propulsora para transformações nas redes que possuíam iniciativas incipientes. Por outro lado, os estados que já possuíam mudanças institucionalizadas, a reforma gerou um efeito menor ou até mesmo a paralisação ou diminuição do ritmo de mudanças. Um dos 
motivos identificados para essa desaceleração ou interrupção das mudanças foi o alto custo de adaptação das medidas já implementadas às propostas oriundas da reforma federal. Por fim, as autoras concluem que "é possível comprovar a hipótese de que, mesmo com alta ambiguidade e curto prazo desde sua aprovação, a reforma já tem causado mudanças no cenário dos estados, já que ela se sobrepõe a processos prévios e encontra um contexto altamente heterogêneo" (LOTTA ET AL, 2019, p.19).

\section{5 - A parceria entre o poder público e o $3^{\circ}$ setor na implementação de políticas}

A relação entre os estados e a sociedade está cada vez mais complexa. Os estados têm cada vez mais compartilhado com outros atores sociais suas funções, estabelecendo parceria para a formulação, implementação e monitoramento de suas políticas públicas, principalmente nas áreas da saúde e da educação. Na pesquisa realizada, Lotta e colegas (2019) consideraram o mapeamento das parcerias estabelecidas para a implementação das iniciativas educacionais e identificaram que quase todos os estados contaram com parcerias institucionais com o terceiro setor. Segundo as autoras, as iniciativas de "Projetos de Vidas" e "Possibilidade de escolher disciplinas" são as que mais estão baseadas nesse tipo de parcerias, tendo presença em mais de $70 \%$ dos estados brasileiros. Com relação às iniciativas de "Orientação e Tutoria" e "Currículo por Competências e Habilidades" esse panorama chega a mais de $50 \%$ dos estados. As autoras analisam que os mesmos atores do terceiro setor circulam por diferentes estados e implementam suas agendas, quase como "pacotes de políticas" e que estes pacotes se materializam em ações de formação docente, auxílio na gestão, apoio no monitoramento e avaliação, entre outros. A existência dessas parcerias corresponde, em todo caso, não apenas à necessidade de apoio técnico que é característica de muitas secretarias municipais e estaduais de educação, mas é também uma decorrência do próprio formato da reforma que estimula, pela omissão e os conflitos que envolvem as relações entre o MEC e as secretarias de educação, as relações com o terceiro setor.

Para a melhor compreensão sobre a complexidade dessa relação entre o Poder Público e o terceiro setor torna-se necessário aprofundar a análise da reforma 
gerencial da administração pública brasileira de 1995, que se constitui em um marco na história das Políticas Públicas do Brasil.

Uma das características da reforma gerencial do Estado, segundo Bresser Pereira (2000) é a separação entre as atividades que antes eram exclusivas do Estado das atividades que poderiam ser assumidas por organizações públicas não estatais. Com relação aos serviços não exclusivos do Estado, o autor caracteriza três possibilidades: aqueles que ficam sob o controle do Estado, aqueles que podem ser privatizados e aqueles que podem ser financiados ou subsidiados pelo Estado, mas com o controle da sociedade.

Segundo Bresser Pereira (2000), a reforma possui um caráter de transição entre um Estado produtor de bens e serviços e um Estado gerencial, não se resumindo apenas à criação de agências reguladoras. Segundo o autor "é também o Estado democrático e eficiente, que financia a fundo perdido os serviços sociais e de pesquisa científica e age como capacitador (enabler) da competitividade das empresas privadas.”. Trata-se de uma mudança na estratégia de gestão, que define um novo enquadramento para as atividades do Estado que está para além de responsabilidades junto a estados e municípios.

Na educação, os processos de formulação e de implementação de políticas estão cada vez mais envolvidos em complexas redes de agentes e instituições nãogovernamentais. Essas redes muitas das vezes operam dentro de uma complexa arquitetura de relações econômicas e sociais e revelam ter um peso considerável na determinação de métodos, conteúdos e propósitos da educação (BALL; AVELAR, 2018), bem como na introdução de novas lógicas no processo educacional, muitas das vezes baseadas nos princípios de eficiência, competitividade e resultados. (PERONI et al, 2013). 


\section{A Política Educacional do Estado do Mato Grosso}

O presente capítulo possui como objetivo apresentar dados, informações e análises que caracterizam o contexto socioeconômico e educacional no estado do Mato Grosso. Tais informações visam subsidiar a compreensão do contexto estadual de implementação da reforma do Ensino Médio.

\section{1 - Contextualização socioeconômica do Mato Grosso}

O estado do Mato Grosso integra a região Centro-Oeste e a Amazônia Legal $^{15}$. Sendo o maior estado em dimensão territorial de sua região e o terceiro em dimensão territorial do Brasil, faz fronteira com seis estados: Amazonas, Pará, Goiás, Tocantins, Mato Grosso do Sul e Rondônia, além da Bolívia.

Mato Grosso possui uma história de povoamento ligada às descobertas de ricos veios auríferos, no inicio do século XVIII. Em 1947 o estado viveu uma nova história política que promoveu, de governo a governo, seu processo de colonização com colonos de diferentes regiões do Brasil e até mesmo "brasiguaios". Neste momento, normas governamentais rígidas executadas por particulares regularam os projetos colonizadores e ofereceram a infraestrutura básica de escolas, postos de saúde, estradas e demais serviços. Esse período se caracterizou pela relação entre o público e o privado, em uma forma pioneira de colonização (FERREIRA, 1997 apud SOUZA e SOUZA, 2003, p. 53).

No estado nasceram municípios essencialmente agropecuários com modelos de monocultura no domínio de latifúndios. Nesse período, Mato Grosso recebeu colonos de diversas regiões, sendo um período de migração maciça. Como resquícios desse processo de migração, o Mato Grosso chegou a ter uma população

\footnotetext{
${ }^{15} \mathrm{O}$ conceito de Amazônia Legal foi instituído pelo governo brasileiro como forma de planejar e promover o desenvolvimento social e econômico dos estados da região amazônica, que historicamente compartilham os mesmos desafios econômicos, políticos e sociais. Baseados em análises estruturais e conjunturais, seus limites territoriais tem um viés sociopolítico e não geográfico, isto é, não são definidos pelo bioma Amazônia. O Eco. O que é a Amazônia Legal. 2020. Disponível em < https://www.oeco.org.br/dicionario-ambiental/28783-o-que-e-a-amazonia-legal/> acessado em 14 de maio de 2020.
} 
de migrantes maior do que a de provenientes do próprio estado (FERREIRA, 1997 apud SOUZA e SOUZA, 2003, p. 53).

Na década de 80 e no final da década de 70 o estado teve substancial ampliação e melhoria de sua malha rodoviária promovida pelo Governo Federal, a abertura de novas fronteiras agrícolas, a expansão das telecomunicações e o recebimento de um substancial número de migrantes do Sul do Brasil (FERREIRA, 1997 apud SOUZA e SOUZA, 2003, p. 53).

\section{Aspectos demográficos}

Segundo dados do censo 2010, o estado do Mato Grosso possui uma população estimada em 3.035.122, representando $1,6 \%$ da população nacional e 21,6\% em comparação à região Centro Oeste, e é dividida em 141 municípios.

Sua capital, o município de Cuiabá, concentra a maior parte da população que, segundo o último censo, possui $551.098^{16}$ mil habitantes, representando $18 \%$ da população, seguido do município de Vargem Grande, com 252 mil habitantes.

Segundo dados do censo 2010, a faixa etária no Mato Grosso é em sua maioria de pessoas adultas, representando $57 \%$ da população entre 20 a 59 anos. Em seguida vem os jovens entre 0 a 19 anos, representando $35 \%$ da população e por último os idosos, caracterizado por pessoas com mais de 59 anos, representando 7,9\% da população.

Com relação à cor ou raça, Mato Grosso possui em sua maioria pardos, com 1,6 milhões de habitantes, representando $52,8 \%$ da população, seguido da população branca, representando $37,2 \%$ com 1,1 milhões de habitantes, em seguida a população negra com 225 mil habitantes, representando $7,4 \%$ da população, seguido da população indígena que representa 1,4\% de sua população com 43 mil habitantes e, por último, a amarela, com 35 mil habitantes e representando 1,2\% de toda a população mato grossense. Sua população economicamente ativa é de cerca de 1,5 milhões de pessoas.

\footnotetext{
${ }^{16}$ Dado referente ao último censo realizado no ano de 2010. Em 2019 a população estimada é de 612.547
} 
Com relação à taxa de migrantes, Mato Grosso possui em sua população $30,64 \%$ de habitantes oriundos de outras regiões do Brasil e $0,19 \%$ oriundos de outros países.

Do total de habitantes no estado, 2.482,801 pessoas residem na área urbana, enquanto 552.321 residem na área rural. O índice de desenvolvimento humano IDH, que é uma medida comparativa usada para classificar os países pelo seu grau de "desenvolvimento humano", considera as variáveis educação, saúde e renda. O IDH é de $0,725 \%$ no estado, posicionando-se em $11^{\circ}$ lugar no Brasil e sendo o último em sua região.

Tabela 1 - Índice de desenvolvimento humano - IDH

ÍNDICE DE DESENVOLVIMENTO HUMANO - IDH

\begin{tabular}{l|ccc}
\hline & $\mathbf{1 9 9 1}$ & $\mathbf{2 0 0 0}$ & $\mathbf{2 0 1 0}$ \\
BRASIL & 0,447 & 0,612 & 0.699 \\
MATO GROSSO & 0,449 & 0,601 & 0,725 \\
GOIÁS & 0,487 & 0,615 & 0,735 \\
MATO GROSSO DO SUL & 0,488 & 0,613 & 0,729 \\
DISTRITO FEDERAL & 0,616 & 0,725 & 0,824 \\
\hline
\end{tabular}

Tabela criada pelo pesquisador. Fonte dos dados: IBGE

Esses dados permitem compreender, ao menos em parte, os desafios que a dimensão territorial e a diversidade racial e cultural do Mato Grosso colocam para a educação pública.

\section{Aspectos Econômicos}

O estado de Mato Grosso é conhecido como o celeiro do Brasil devido a sua grande produção de soja, milho, algodão e de rebanho bovino. Cinco outros setores do estado possuem grande potencial de crescimento na região e têm ganhado atenção especial do estado a agroindústria, turismo, piscicultura, economia criativa e polo joalheiro. 
Mato Grosso possui um agronegócio consolidado e, segundo a Federação das Indústrias no Estado de Mato Grosso (Fiemt), em 2013, o estado tinha 11.398 unidades industriais em operação, com 166 mil empregos gerados. O estado é também o maior produtor de pescado de água doce do país, em virtude da sua abundância de rios e lagos em todo o território. Se seu período de colonização foi marcado pelo ouro, hoje o estado se tornou um potencial para a fabricação de joias, sendo o maior produtor de diamante do Brasil. O ecoturismo também se destaca na região devido a suas cachoeiras, safaris, trilhas, mergulhos, observação de pássaros, dentre outras belezas naturais. Dados do IBGE apontam que o Produto Interno Bruto - PIB do estado é de R $\$ 126.805$ milhões, sendo a maior taxa de crescimento no país.

\section{2 - Dados Educacionais}

\section{Matrículas, escolas e docentes}

O Estado do Mato Grosso possui 2.713 escolas de educação básica, atendendo a 878.246 alunos, sendo destes 140.492 do Ensino Médio. Segundo dados do IBGE o estado assume a $15^{a}$ posição no Brasil em número de matrículas no Ensino Médio.

Tabela 2 - Número de matrículas - Ensino Médio

NÚMERO DE MATRÍCULAS - ENSINO MÉDIO

\begin{tabular}{l|l}
\hline BRASIL & 7.709 .929 \\
REGIÃO CENTRO OESTE & 585.492 \\
MATO GROSSO & 140.492
\end{tabular}

Tabela criada pela pesquisadora. Fonte dos dados: Censo Escolar/ INEP 2018

O número de matrículas referente ao Ensino Médio da rede estadual de Mato Grosso corresponde a 1,82\% de todo o Brasil e a 23,99\% das matrículas oferecidas pela Região Centro Oeste, da qual faz parte junto com os estados do Mato Grosso do Sul (MS), de Goiás (GO) e do Distrito Federal (DF). 
Tabela 3 - Panorama de matrículas na Educação Infantil no Mato Grosso

EDUCAÇÃO INFANTIL

\begin{tabular}{l|lll}
\hline & Escolas & Matrículas & \% Matrículas \\
ESTADUAL & 05 & 612 & $0,36 \%$ \\
MUNICIPAL & 1.226 & 144.161 & $85,8 \%$ \\
PRIVADA & 347 & 23.122 & $13,77 \%$
\end{tabular}

Tabela criada pela pesquisadora. Fonte dos dados: Censo Escolar/ INEP 2018

Tabela 4 - Panorama de matrículas no Ensino Fundamental no Mato Grosso

ENSINO FUNDAMENTAL

\begin{tabular}{l|lll}
\hline & Escolas & Matrículas & \% Matrículas \\
ESTADUAL & 654 & 199.230 & $42,24 \%$ \\
MUNICIPAL & 997 & 214.949 & $45,57 \%$ \\
PRIVADA & 309 & 57.434 & $12,17 \%$
\end{tabular}

Tabela criada pela pesquisadora. Fonte dos dados: Censo Escolar/ INEP 2018

Tabela 5 - Panorama de matrículas no Ensino Médio no Mato Grosso

ENSINO MÉDIO

\begin{tabular}{l|lll}
\hline & Escolas & Matrículas & \% Matrículas \\
ESTADUAL & 504 & 121.858 & $87,0 \%$ \\
MUNICIPAL & 0 & 0 & $0 \%$ \\
FEDERAL & 19 & 7.674 & $5,48 \%$ \\
PRIVADA & 119 & 10.487 & $7,49 \%$
\end{tabular}

Tabela criada pela pesquisadora. Fonte dos dados: Censo Escolar/ INEP 2018

A rede municipal é a principal responsável pelas matrículas da educação infantil $(85,8 \%)$. No ensino fundamental, o estado praticamente divide as matrículas com os municípios, ofertando, respectivamente, 45,57\% e 42,24\% das matrículas. No Ensino Médio a rede estadual pública é a principal responsável pelo atendimento com $87 \%$, enquanto a rede privada atende a $7,49 \%$ do total de matrículas.

A rede mato-grossense também é responsável pela gestão de escolas indígenas e quilombolas. Em pesquisa realizada na base de dados "Catálogos de 
Escolas" do Inep data, selecionando o descritor "Terra Indígena" foram identificadas 192 escolas no estado, sendo 71 sob a gestão estadual (anexo 2). Utilizando a mesma base de pesquisa, agora com o descritor “Área Remanescente de Quilombos" foram identificadas 10 escolas, sendo 5 com gestão do estado (anexo 3).

Tabela 6 - Taxa líquida de matrículas

TAXA LÍQUIDA DE MATRICULAS

\begin{tabular}{l|ccccc}
\hline & $\mathbf{2 0 1 4}$ & $\mathbf{2 0 1 5}$ & $\mathbf{2 0 1 6}$ & $\mathbf{2 0 1 7}$ & $\mathbf{2 0 1 8}$ \\
FUNDAMENTAL BRASIL & 97,1 & 97,3 & 97,3 & 97,7 & 98,0 \\
FUNDAMENTAL MT & 96,4 & 96,8 & 97,4 & 98,0 & 97,7 \\
ENSINO MÉDIO BRASIL & 64,2 & 65,4 & 67,3 & 67,5 & 68,7 \\
ENSINO MÉDIO MT & 74,7 & 75,1 & 80,0 & 77,7 & 77,4 \\
\hline
\end{tabular}

Fonte dos dados: PNAID Contínua - Todos pela Educação

No que tange à taxa líquida de matrículas, o Brasil apresenta crescimento nas etapas de ensino fundamental e médio. No ensino fundamental o país está próximo da universalização. Em 2018, a taxa líquida de matrícula chegou a 98\%. No Ensino Médio esse percentual também aumenta, chegando, em 2018, a 68,7\%, mas está longe dos $85 \%$ previsto na meta 3 do PNE.

No Mato Grosso a etapa do ensino fundamental apresenta crescimento na taxa líquida de matriculas, no período de 2014 a 2017, e apresenta pequena queda no ano de 2018. A etapa, como no Brasil, caminha para sua universalização no estado. A etapa do Ensino Médio no estado apresenta crescimento no período de 2014 a 2016 seguido de queda nos anos posteriores e alcançando 77,4\% em 2018. Verifica-se que, enquanto o ensino fundamental atinge quase a sua universalização, o Ensino Médio carece de políticas na educação básica focadas no acesso e permanência dos alunos, que, conforme explicitado no documento da Base Nacional Comum Curricular é, atualmente, o gargalo da educação nacional. 
Tabela 7 - Percentual de jovens de 19 anos que concluíram o Ensino Médio

\section{JOVENS DE 19 ANOS QUE CONCLUÍRAM O ENSINO MÉDIO}

\begin{tabular}{l|lllll}
\hline & $\mathbf{2 0 1 4}$ & $\mathbf{2 0 1 5}$ & $\mathbf{2 0 1 6}$ & $\mathbf{2 0 1 7}$ & $\mathbf{2 0 1 8}$ \\
BRASIL & $55,7 \%$ & $55,9 \%$ & $58,9 \%$ & $59,2 \%$ & $63,3 \%$ \\
MATO GROSSO & $55,1 \%$ & $57,7 \%$ & $62,8 \%$ & $55,7 \%$ & $65,6 \%$ \\
\hline
\end{tabular}

Fonte dos dados: PNAID Contínua - Todos pela Educação

O número de jovens de 19 anos que concluíram o Ensino Médio no Brasil apresenta crescimento, chegando a 63,3\% em 2018. No Mato Grosso esse indicador chega a 65,6\% em 2018, colocando-se acima da média nacional.

A taxa de rendimento escolar é gerada a partir da soma da quantidade de alunos aprovados, reprovados e que abandonaram a escola ao final do ano letivo. A partir de dados coletados no Censo Escolar no período de 2010 a 2018 foi realizado um levantamento do desenvolvimento da rede estadual do Mato Grosso com relação à taxa de rendimento no Ensino Médio:

Tabela 8 - Quadro com os percentuais de aprovação, abandono e aprovação no Ensino Médio

\begin{tabular}{l|lll} 
ANO & REPROVAÇÃO & ABANDONO & APROVAÇÃO \\
\hline $\mathbf{2 0 1 0}$ & $17,2 \%$ & $11,3 \%$ & $71,5 \%$ \\
$\mathbf{2 0 1 1}$ & $18,3 \%$ & $11,5 \%$ & $70,2 \%$ \\
$\mathbf{2 0 1 2}$ & $20,0 \%$ & $13,1 \%$ & $66,9 \%$ \\
$\mathbf{2 0 1 3}$ & $21,7 \%$ & $13,6 \%$ & $64,7 \%$ \\
$\mathbf{2 0 1 4}$ & $21,6 \%$ & $12,4 \%$ & $65,9 \%$ \\
$\mathbf{2 0 1 5}$ & $18,6 \%$ & $13,4 \%$ & $68,0 \%$ \\
$\mathbf{2 0 1 6}$ & $20,2 \%$ & $10,4 \%$ & $69,4 \%$ \\
$\mathbf{2 0 1 7}$ & $16,6 \%$ & $10,2 \%$ & $73,2 \%$ \\
$\mathbf{2 0 1 8}$ & $15,0 \%$ & $9,3 \%$ & $75,8 \%$
\end{tabular}

Tabela criada pelo pesquisador. Fonte dos dados: Censo Escolar/ INEP 
Apesar do quadro não apresentar muitas mudanças ao longo dos anos, evidencia-se que o estado teve uma queda no índice de reprovação e abandono nos anos de 2017 e 2018 e um crescimento nas taxas de aprovação neste mesmo período, o que se configura em um cenário positivo.

Tabela 9 - Quadro com a evolução das notas do SAEB no Ensino Médio da rede estadual

\section{EVOLUÇÃO DAS NOTAS DO SAEB NO $3^{\circ}$ ANO}

\begin{tabular}{l|lcccc}
\hline & $\mathbf{2 0 0 9}$ & $\mathbf{2 0 1 1}$ & $\mathbf{2 0 1 3}$ & $\mathbf{2 0 1 5}$ & $\mathbf{2 0 1 7}$ \\
PORTUGUÊS & 253,55 & 258,10 & 250,98 & 259,98 & 256,79 \\
\hline MATEMÁTICA & 254,61 & 261,22 & 255,69 & 257,74 & 258,02 \\
\hline
\end{tabular}

Fonte dos dados: QEdu.org.br. Dados do Ideb/Inep (2017)

A tabela apresenta a evolução dos dados de proficiência em matemática e português no Ensino Médio do estado do Mato Grosso, considerando o período de 2009 a 2017. Em português o estado apresenta um crescimento entre os anos de 2009 a 2011, mas com queda no período seguinte, 2013. Em 2015 o estado tem um crescimento considerável de 9 pontos percentuais, chegando a 259,98, mas o índice voltou a cair em 2017, chegando a 256,79. Em matemática o crescimento se mostra mais constante no período, apesar da diminuição no ano 2013, com uma queda de mais de 5 pontos percentuais. Os anos de 2015 e 2017 apresentam leve crescimento, chegando a 258,02 no último período relatado. 


\section{Escolas e docentes}

Com relação ao número de escolas de Ensino Médio, dados do IBGE sinalizam que houve um aumento crescente de unidades e que Mato Grosso ocupa a $14^{a}$ posição, no Brasil, em número de escolas.

Gráfico 1 - Número de escolas de Ensino Médio no Mato Grosso

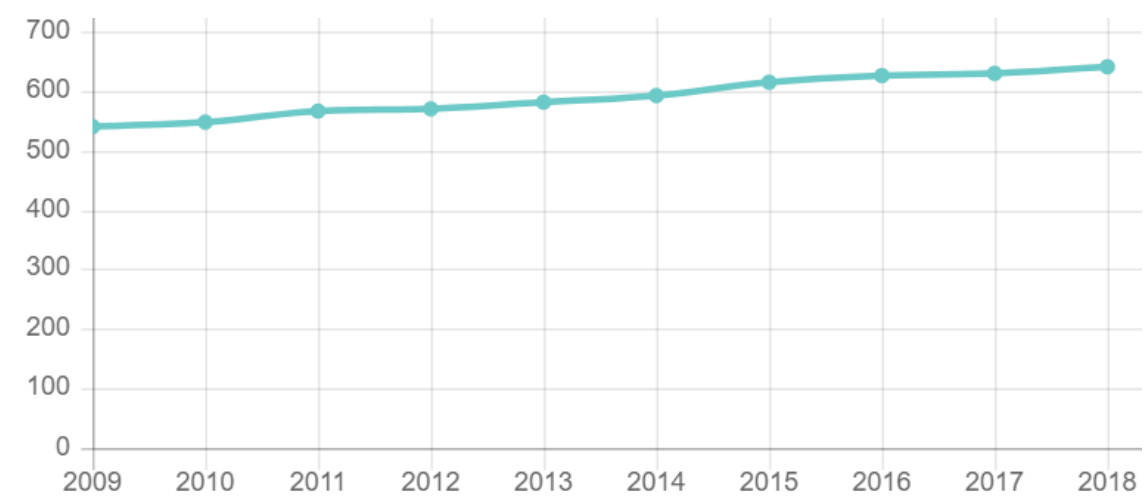

Fonte dos dados: Censo Escolar/ INEP

Com relação ao número de docentes, o Estado também apresenta um aumento considerável nos últimos anos e ocupa a $13^{\mathrm{a}}$ posição no Brasil:

Gráfico 2 - Número de docentes que atuam no Ensino Médio no Mato Grosso

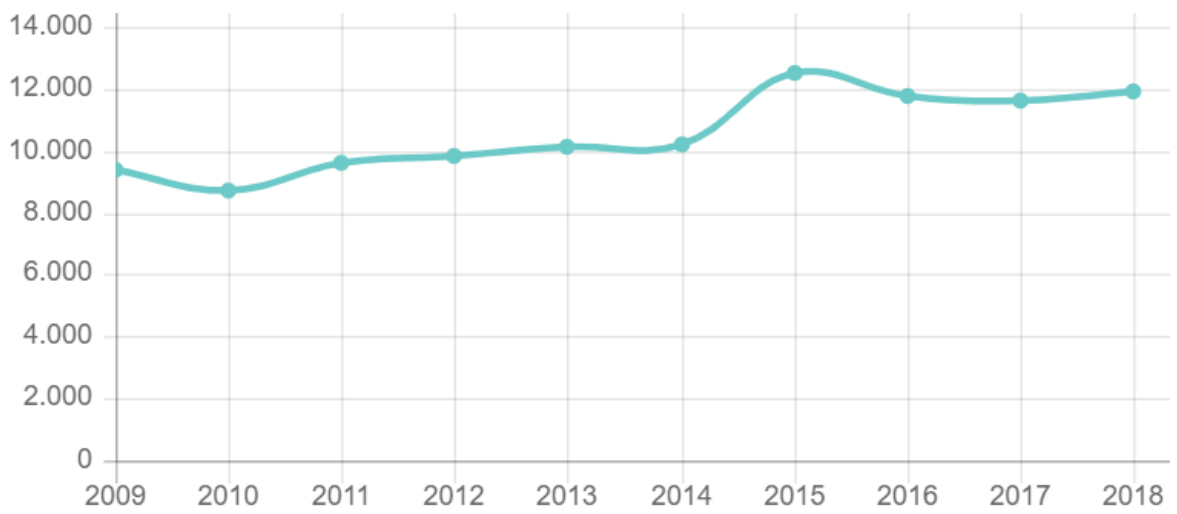

Fonte dos dados: Censo Escolar/ INEP 


\section{Índice de Desenvolvimento da Educação Básica do Mato Grosso}

O Índice de Desenvolvimento da Educação Básica (Ideb) é o principal indicador da qualidade da educação básica no Brasil. O índice reúne, em um só indicador, os resultados de dois conceitos importantes para a qualidade da educação: a) pontuação média dos estudantes em exames padronizados ao final de determinada etapa do ensino fundamental ( $4^{\mathrm{a}} / 5^{\mathrm{a}}$ e $8^{\mathrm{a}} / 9^{\mathrm{a}}$ séries $)$ e $3^{\circ}$ ano do Ensino Médio; e b) taxa média de aprovação dos estudantes da correspondente etapa de ensino (FERNANDES, 2007).

O Ideb 2017 no Ensino Médio da rede estadual cresceu, chegando a 3,2, mas não atingiu a meta de 3,9. A rede tem o desafio de garantir mais alunos aprendendo e com um fluxo escolar adequado.

Gráfico 3 - Evolução do IDEB no Brasil e Mato Grosso

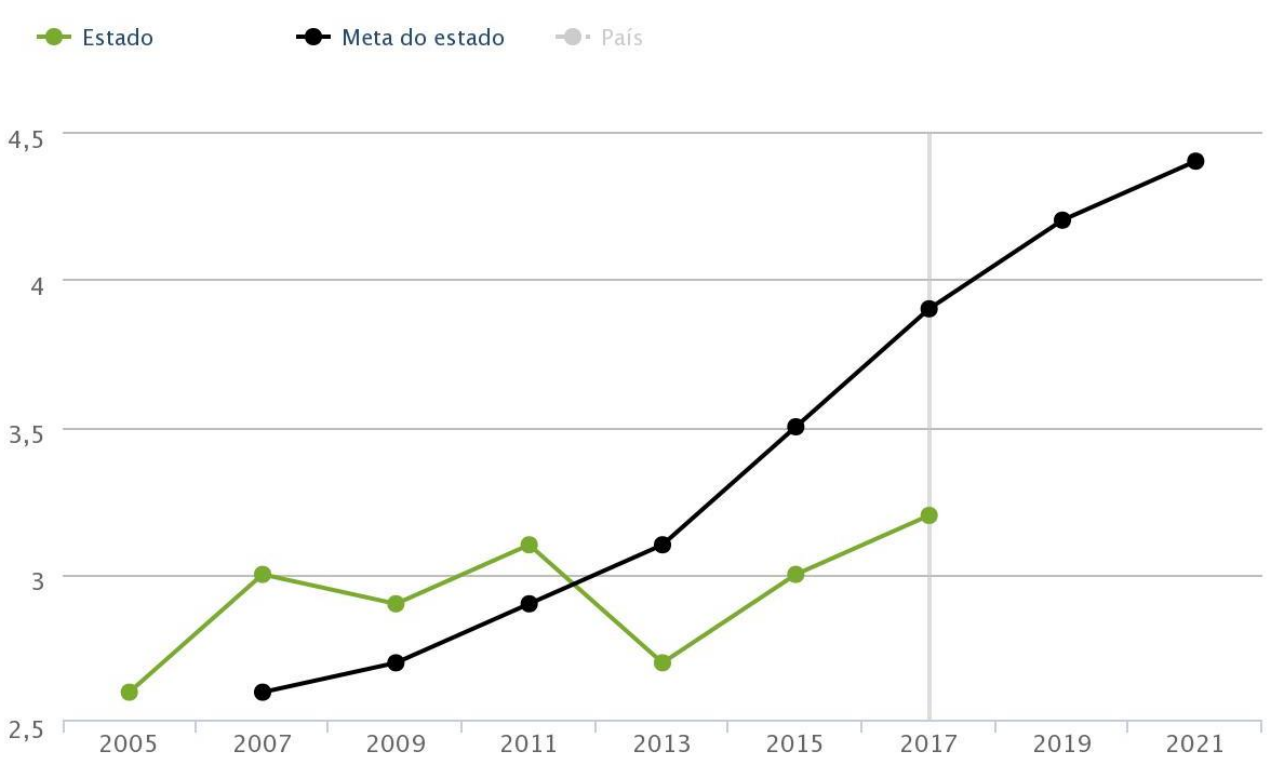

Fonte: QEdu.org.br. Dados do Ideb/Inep (2017).

Os dados apresentados sinalizam para as defasagens de aprendizagem na transição para o Ensino Médio que, apesar dos investimentos realizados pelo estado nos últimos anos, apresentados na introdução, os desafios relacionados ao acesso 
para a etapa se mantêm. Em vistas a essas análises sobre ao acesso e aprendizagem, seguiremos para a próxima seção com a análise do Plano Estadual de Educação.

\section{Plano Estadual de Educação do Mato Grosso}

Os Planos Estaduais de Educação - PEEs se configuram em importantes instrumentos de gestão, pois possuem como intencionalidade integrar objetivos e metas do plano nacional, traduzindo-os, portanto, para a realidade territorial do estado, assim como articular as demandas municipais, propiciando que os municípios possam se adequar ao planejamento nacional e que considerem suas particularidades (SOUZA; MENEZES, 2015).

Em que pese a importância dos Planos Estaduais de Educação, a Lei n ${ }^{\circ}$ 13.005/2014 estabeleceu que os entes federativos infranacionais deveriam “elaborar seus correspondentes planos de educação, ou adequar os planos já aprovados em lei”, em relação às diretrizes, metas e estratégias estabelecidas no PNE 2014-2024, “no prazo de 1(um) ano" (MENEZES; SOUZA, 2018).

Segundo dados disponibilizados na plataforma do MEC, o estado do Mato Grosso cumpriu todas as etapas previstas. A lei nº10.111, de 06 de junho de 2014 dispõe sobre a lei nº8.806, de 10 de janeiro de 2008, que institui o Plano Estadual de Educação de Educação do Mato Grosso.

O estado estabeleceu uma relação de 17 metas com suas respectivas estratégias. Com relação às ações voltadas ao Ensino Médio, destaca-se a meta 09 que dispõe sobre a garantia da oferta de Ensino Médio a 100\% da demanda, com acréscimos anuais de $25 \%$ (vinte e cinco por cento) até 2017. A meta possui como indicador o número de matrículas no Ensino Médio em relação à população escolarizável e apresenta as seguintes estratégias:

1. Garantir a relação professor/estudante, infraestrutura e material didático adequados ao processo educativo, considerando as características desta etapa de ensino, conforme os padrões do CAQ -Custo Aluno Qualidade.

2. Consolidar a identidade do Ensino Médio, aperfeiçoando a concepção curricular que proporciona formação geral e específica. 
3. Manter e ampliar programas e ações de correção de fluxo, por meio do acompanhamento individualizado do estudante com rendimento escolar defasado e pela adoção de práticas como aulas de reforço no turno complementar, estudos de recuperação e progressão parcial, de forma a reposicioná-lo no ciclo escolar de maneira compatível com sua idade.

4. Redimensionar a oferta de Ensino Médio nos turnos diurno e noturno, bem como a distribuição territorial das escolas de Ensino Médio, de forma a atender a toda a demanda de acordo com as necessidades específicas dos alunos.

5. Implantar, imediatamente, em todas as escolas, uma organização curricular para o ensino noturno regular, de modo a atender as especificidades do aluno trabalhador.

6. Garantir no currículo a inserção de atividades que utilizem outros espaços pedagógicos além da sala de aula, possibilitando o acesso a esses locais em todos os turnos.

7. Implantar e ampliar a oferta do Ensino Médio Integrado à Educação Profissional para atender a demanda.

8. Fomentar a expansão das matrículas gratuitas de Ensino Médio Integrado à Educação Profissional, observando-se as peculiaridades das populações do campo, das comunidades indígenas e quilombolas e das pessoas com deficiência.

9. Garantir cursos profissionalizantes presenciais e a distância, com elevação da escolaridade, para atender demandas específicas, especialmente as comunidades indígenas, quilombolas, trabalhadores que atuam em setores econômicos sazonais e adolescentes em processo de ressocialização.

10. Prover nas escolas de Ensino Médio equipamentos de informática, na proporção mínima de um conjunto (computador conectado à internet, impressora e data show) para cada 35 alunos.

11. Atender, imediatamente, a demanda por Ensino Médio nas populações do campo, nas comunidades indígenas e quilombolas, preferencialmente com professores das próprias comunidades.

12. Estruturar e fortalecer o acompanhamento e o monitoramento do acesso e da permanência dos jovens beneficiários de programas de transferência de renda, no Ensino Médio, quanto à frequência, ao aproveitamento escolar e à interação com o coletivo, bem como das situações de discriminação, preconceitos e violências; práticas irregulares de trabalho, consumo de drogas, gravidez precoce; em colaboração com as famílias e com órgãos públicos de assistência social, saúde e proteção à adolescência e juventude.

(Plano Estadual de Educação do Mato Grosso. 2014, p.29) 
O plano de monitoramento do Plano Estadual, com última atualização em 2018, aponta que a o indicador estava próximo à meta estabelecida, tendo alcançado $89,5 \%$.

Com relação a meta 3 do Plano Nacional sobre a oferta do Ensino Médio Universalizar, até 2016, o atendimento escolar para toda a população de 15 (quinze) a 17 (dezessete) anos e elevar, até o final do período de vigência deste PNE, a taxa líquida de matrículas no Ensino Médio para 85\% (oitenta e cinco por cento). O estado avança no indicador 3A que dispõe sobre o percentual da população de 15 a 17 anos que frequenta a escola ou já concluiu a educação básica, alcançando $83,9 \%$ da meta de $100 \%$ prevista, no entanto com relação ao indicador 3B que dispõe sobre o percentual da população de 15 a 17 anos que frequenta o Ensino Médio ou possui educação básica completa o estado, até o momento da pesquisa, atingiu $63,3 \%$ da meta prevista de $85 \%$.

\section{3 - Políticas Educacionais}

Em conformidade aos preceitos legais da LDB/96, o estado, por meio de sua rede de ensino, oferece todos os níveis da educação básica e, por meio da Universidade do Estado de Mato Grosso - UNEMAT oferece também o ensino superior. Jesus e Farenzena (2012) sinalizam que, em consonância à busca da democratização e da qualidade da educação, o governo do estado do Mato Grosso vem, desde a década de 1990, implementando políticas mais direcionadas ao currículo escolar. Dentre as ações realizadas, destaca-se a implantação, em 1998, do ensino organizado por ciclos de formação, com a criação do Ciclo Básico de Aprendizagem (CBA). Neste mesmo período a secretaria iniciou também uma política de expansão das vagas para o Ensino Médio e criou seu Centros de Formação e Atualização dos Profissionais da Educação Básica de Mato Grosso Cefrapo.

As Orientações Curriculares para a Educação Básica do estado do Mato Grosso (2010) sinalizam que diagnósticos realizados pelo governo em 1997 identificaram um alto índice de evasão $(14,9 \%)$ e repetência $(19,5 \%)$ chegando ao patamar de 34,4\% de fracasso escolar. Em consideração a esses dados, o estado implementou metas de curto, médio e longo prazo. Como primeira ação de combate 
aos dados diagnosticados, o estado instituiu as Leis Complementares 49/98 e 50/98 que versaram sobre a regulamentação do Sistema de Ensino e a carreira de seus profissionais, seguidas de ações voltadas à expansão da oferta de vagas na educação básica e desenho de estratégias para a permanência dos alunos nas escolas. Neste período foi realizada a reorganização do ensino fundamental em ciclos, que se configurou em uma estratégia para o enfrentamento à evasão e repetência. O Ensino Médio também foi foco das ações no mesmo período, como a expansão da oferta de vagas.

Segundo o documento, em 1995, por meio da portaria 1266/95 houve o encerramento dos cursos profissionalizantes na rede estadual. No entanto, em 2004, por meio do decreto 5154/04, as discussões foram retomadas e houve o resgate da proposta de Ensino Médio Integrado que, de acordo com o documento, teve reflexos importantes para as políticas públicas dirigidas a essa etapa.

Em concomitância aos investimentos realizados e com o objetivo de melhoria da educação pública estadual, em 1997, foram criados os Centros de Formação e Atualização dos Profissionais da Educação Básica de Mato Grosso CEFAPRO. Esses centros são órgãos estaduais, subordinados à Superintendência de Formação de Profissionais da Secretaria de Estado de Educação. Sua criação se deu por meio do decreto $\mathrm{n}^{\circ}$ 2.007, que dispõe sobre a criação de Centros de Formação e Atualização do Professor e deu origem a três centros, localizados nas cidades de Cuiabá, Rondonópolis e Diamantino. Esses centros foram ampliados e aprimorados e, em 2005, foram transformados em unidades administrativas da Secretaria de Educação. Essa transformação se caracterizou pelo fortalecimento da política de formação continuada do estado (NOBILE, 2014). Atualmente o estado possui 15 centros de formação distribuídos ao longo do território, conforme especificado a seguir: 
Figura 1- Mapa com a localização dos Cefapros

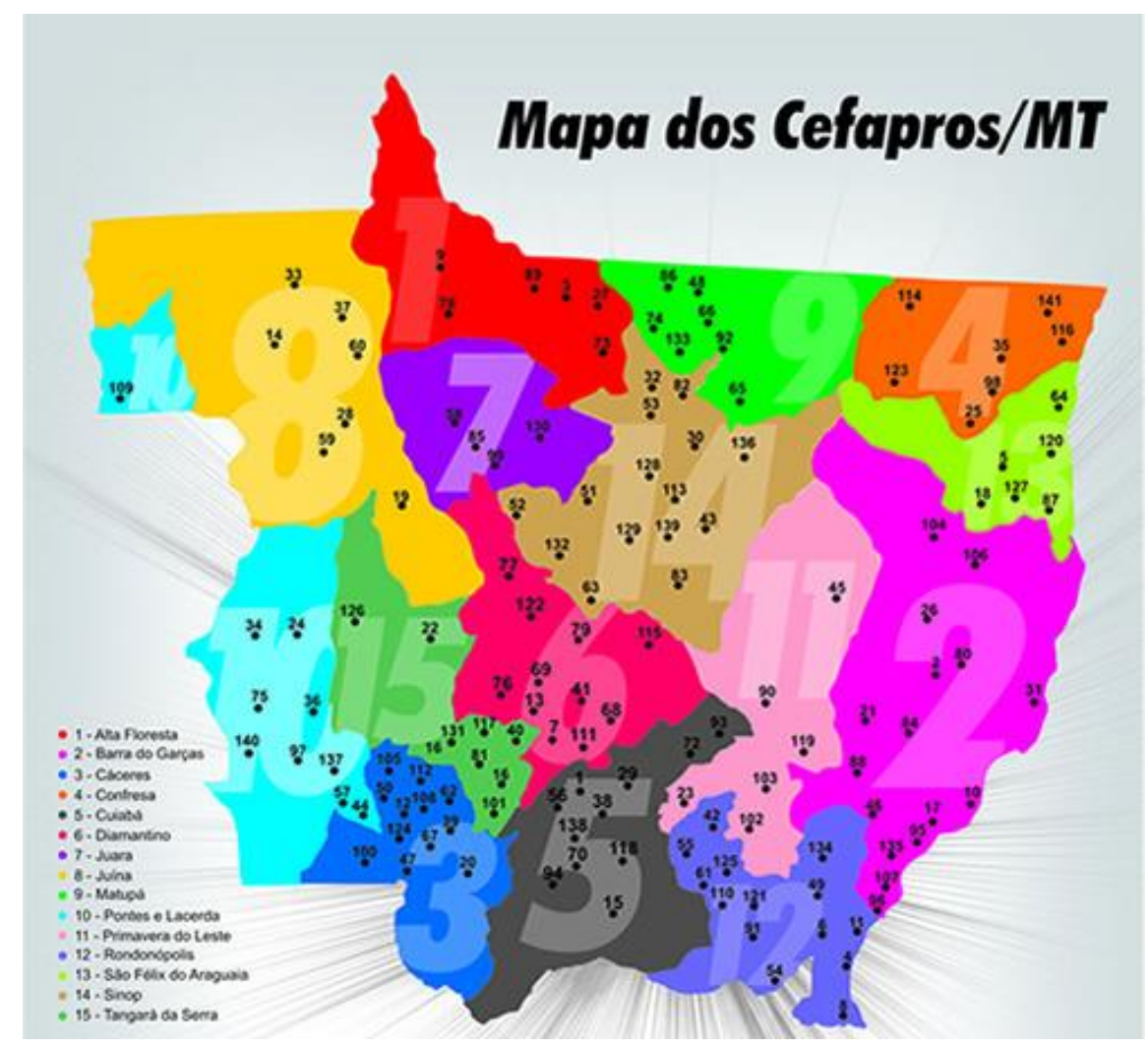

Fonte: Portal do Cefapro de Cuiabá

As Orientações Curriculares para a Educação Básica (2010) sinalizavam em 2010 que um dos maiores desafios a serem vencidos pelo estado em relação ao Ensino Médio era a promoção da ampliação da oferta pública com qualidade, na perspectiva da politecnia, articulando conhecimentos científicos, tecnológicos, culturais e sócios-históricos. Após uma longa descrição acerca da função social do Ensino Médio, o documento apresenta os princípios que expressam o compromisso do estado com essa etapa da educação básica, a saber: universalização, com a progressiva expansão do atendimento desse nível; unidade de orientação, que todos os estudantes tenham acesso à formação geral que os capacite a participar da vida social e produtiva com autonomia intelectual e ética; diversificação de modalidades, com programas diversificados que estimulem a criação de diferentes alternativas aos estudantes; integração entre ciência, trabalho e cultura, garantindo que o currículo compreenda o trabalho enquanto práxis humana e não apenas como práxis produtiva; identidade, construindo, junto à comunidade, a identidade própria da escola de Ensino Médio, que atenda às suas condições e 
necessidades; autonomia para o sistema público estadual, suas instâncias locais e principalmente para as escolas, tal como determinado na LDB; avaliação, prestando contas pelo sistema público de educação e pelas escolas, assim como sua utilização para a tomada de decisões mais assertivas e; estrutura, garantindo que a oferta do Ensino Médio mantenha uma única estrutura e que assegure a todo educando os mesmos direitos relativos às certificação e à qualidade.

Mesmo após 10 anos, os desafios elencados nas orientações curriculares para a educação básica do Mato Grosso continuam colocados para o Ensino Médio.

A rede estadual, desde 2011, implementa o Ensino Médio Inovador (EMI), que é um programa do Ministério da Educação, instituído pela Portaria $n^{\circ} 971$, de 9 de outubro de 2009, no contexto da implementação das ações voltadas ao Plano de Desenvolvimento da Educação - PDE e que atualmente está alinhado às diretrizes e metas do Plano Nacional de Educação 2014-2024 e à reforma do Ensino Médio.

O EMI visa garantir o acesso à educação de qualidade aos jovens do Ensino Médio e para tal realiza ações conjuntas com estados e Distrito Federal, desenvolvendo propostas curriculares inovadoras nas escolas de Ensino Médio por meio de apoio técnico e financeiro do Governo Federal, consoante à disseminação da cultura de um currículo dinâmico, flexível, que atenda às expectativas e necessidades dos estudantes e às demandas da sociedade atual (PORTAL MEC, 2020).

As ações desenvolvidas pelos estados e Distrito Federal devem considerar as diferentes áreas do conhecimento e desenvolver atividades nos seguintes Campos de Integração Curriculares (CIC):

I - Acompanhamento Pedagógico (Língua Portuguesa e Matemática);

II - Iniciação Científica e Pesquisa;

III - Mundo do Trabalho;

IV - Línguas Adicionais/Estrangeiras;

V - Cultura Corporal;

VI - Produção e Fruição das Artes;

VII - Comunicação, Uso de Mídias e Cultura Digital;

VIII - Protagonismo Juvenil.

(PORTAL MEC, 2020). 
A proposta do EMI é que as ações sejam incorporadas gradativamente ao currículo escolar, propiciando a ampliação do tempo na escola, na perspectiva da educação integral, e ampliando a diversidade de práticas pedagógicas de modo que se traduzam na qualificação dos currículos das escolas de Ensino Médio (PORTAL MEC, 2020).

Dentre as inciativas atuais do estado do Mato Grosso direcionadas ao Ensino Médio, destaca-se a criação, em 2017, das Escolas Plenas, nova denominação dada pelo estado às escolas do programa de EMI do MEC. São escolas de ensino integral onde os estudantes, além das disciplinas tradicionais, recebem orientações especializadas, na perspectiva de contribuir para a formação de um projeto de vida, que é uma iniciativa que propicia ao estudante fazer escolhas alinhadas à cidadania e ao seu projeto de vida com autonomia, liberdade, responsabilidade e criticidade, a partir da valorização e apropriação de conhecimentos e experiências. Essa política foi instituída pela lei ${ }^{\circ} 10.622$ de 24 de outubro de 2017 e está vinculada ao Programa Pró- Escolas ${ }^{17}$. Segundo disposto na lei, o projeto Escola Plena possui as seguintes diretrizes:

I - desenvolver ações inovadoras relativas ao currículo e à gestão escolar, direcionadas à melhoria da qualidade do ensino na rede estadual de educação;

II - sistematizar, implementar e difundir o modelo de educação integral na rede estadual de ensino;

III - oferecer atividades que influenciem práticas inovadoras ao processo de ensino aprendizagem, a fim de melhorar a sua qualidade;

IV - estimular a participação da comunidade escolar na elaboração do projeto político pedagógico da escola;

V - ampliar a jornada escolar, a fim de promover a formação integral e integrada do estudante;

VI - integrar o Ensino Médio à educação profissional;

VII - viabilizar parcerias com o Governo Federal, instituições de ensino e pesquisa e instituições públicas ou privadas com vistas a colaborar com a expansão da educação integral no âmbito do Estado de Mato Grosso.

(LEI N ${ }^{\circ}$ 10.622, DE 24 DE OUTUBRO DE 2017, p.1)

\footnotetext{
17 O Pró-Escolas é um programa educacional do Estado e tem a finalidade de promover ações e investimentos para melhorar a estrutura das escolas estaduais e a qualidade da educação pública. Um dos principais intuitos é combater a evasão escolar em Mato Grosso, dentre as principais ações desenvolvidas está a implementação das escolas Plenas no Ensino Médio.
} 
A lei faz menção ao processo de seleção das escolas que implementarão a proposta, explicitando que serão aplicados critérios para essa escolha e que os profissionais que atuarão no projeto serão submetidos a processo seletivo.

Pelas pesquisas realizadas, o projeto Escolas Plenas se configura na principal ação direcionada ao Ensino Médio pelo estado, apesar de acontecer em formato piloto em um baixo número de escolas, apenas 39, segundo informações disponibilizadas no site da secretaria de educação e entrevistas.

A reforma do Ensino Médio chega ao Mato Grosso em um contexto onde ações já estavam em curso e isso influencia a configuração da implementação da reforma do Ensino Médio no estado. Lotta et al (2019a) argumentam que existem "poucas evidências na literatura sobre quais foram as implicações concretas da reforma para os estados, considerando que parte deles já vinha em movimento de mudanças". Seus estudos sinalizam (LOTTA ET AL, 2019a) que o Mato Grosso, desde 2008, implementa ações nos eixos de Formação Integral e Protagonismo do Estudante, Inovações Curriculares e Novos Formatos de Ensino e Educação Profissional e Técnica. Esses eixos foram trabalhados no capítulo sobre as políticas educacionais do Ensino Médio e analisados com relação às experiências de todos os estados brasileiros. Com relação ao Mato Grosso, que é o objeto deste capítulo, o estado realiza, desde 2016 ações voltadas ao projeto de vida, possuindo 40 experiências ao total, o que representa $8 \%$ de sua rede e, desde 2017 , vêm implementando ações relacionadas à eletividade ${ }^{18}$ e tutoria $^{19}$, possuindo 40 experiências em cada tipo de ação, o que representa $8 \%$ da rede estadual. Tais iniciativas fazem parte do eixo de Formação Integral e Protagonismo do Estudante e tiveram seu início no mesmo período em que houve a aprovação da reforma do Ensino Médio e das iniciativas de incentivo e indução do Governo Federal para a adoção do EMTI. No eixo Inovações Curriculares e Novos Formatos de Ensino, o estado apresenta experiências com currículo que integra disciplinas, desde 2008, com 120 ações que abrangem $24 \%$ da rede. Este eixo mostra que a mudança curricular se dá em caráter experimental, visto que são poucas experiências, e representa uma iniciativa do próprio estado e não um movimento nacional de mudança curricular, como pode ser visto pelo ano em que foram implementadas

\footnotetext{
${ }^{18}$ A eletividade está relacionada à possibilidade de escolha dos estudantes (Lotta et al (2019a).

${ }^{19}$ A tutoria está relacionada ao desenvolvimento de atividades de orientação (Lotta et al (2019a).
} 
tais ações (2008). No eixo Educação Profissional e Técnica o estado apresenta 36 experiências de atividades que incorporam o mundo do trabalho, abrangendo 7,5\% da rede. Esta experiência acontece no Mato Grosso desde 2008, significando que também é uma iniciativa de caráter incremental do próprio estado (LOTTA ET AL, $\left.2019^{a}\right)$.

Os dados apresentados neste capítulo contribuem para a compreensão do contexto no qual a reforma do Ensino Médio, ou o Novo Ensino Médio como se convencionou chamar atualmente, se insere ao chegar no estado do Mato Grosso. Historicamente o Ensino Médio é um desafio a nível nacional e isso se projeta no estado que é o objeto deste estudo. A reforma do Ensino Médio chega em um período no qual a rede tem apresentado iniciativas para a ampliação e melhoria do quadro educacional desta etapa, apesar de muitas dessas iniciativas estarem presentes apenas nos documentos oficiais, e serem pouco materializadas em ações ou projetos. Posto isso, a pesquisa segue para sua etapa principal, a análise do processo de implementação da reforma no estado. 


\section{O Currículo e o Novo Ensino Médio no estado do Mato Grosso}

Neste capítulo serão apresentados os resultados da pesquisa relativos à implementação da reforma do Ensino Médio no estado do Mato Grosso. As entrevistas tiveram como objetivo identificar como acontece, na percepção de agentes da SEE-MT, o processo de implementação da reforma do Ensino Médio no estado, considerando as relações federativas e burocráticas, o papel indutor do Governo Federal e os impactos da reforma nas mudanças em curso.

Na análise documental e no conteúdo das entrevistas sobre a implementação do Novo Ensino Médio no estado do Mato Grosso, são mobilizados os estudos de Lotta e Bauer (2018) e de Lotta e colegas (2019), que investigam a implementação da reforma nos estados brasileiros; a abordagem dos contextos de implementação de Matland (1995) com o binômio ambiguidade-conflito; Hupe e Hill (2003), com as relações entre camadas federativas e níveis burocráticos; e Lindblom (1979) com a visão da política pública como um processo incremental, conforme apresentado no primeiro capítulo.

Foram entrevistados três gestores educacionais da SEE-MT envolvidos diretamente com a reforma, que serão nomeados como Gestor Educacional 1, 2 e 3, para garantir a preservação do anonimato, conforme pactuado na assinatura do TCLE.

O GE1 pertence ao alto escalão da secretaria, e os GE2 e GE3 são implementadores do médio escalão, vinculados à Coordenadoria de Desenvolvimento do Ensino Médio do estado do Mato Grosso.

\section{1 - Relações federativas e burocráticas na implementação do Novo Ensino Médio no estado de Mato Grosso}

Em estudo sobre os processos de mudança no Ensino Médio brasileiro, Lotta e Bauer (2018) analisam as trajetórias de reformas nos estados, os sentidos das 
mudanças e em que medida esses sentidos foram, ou não, alterados pela aprovação da reforma do ensino médio, no período de 2016-2018. Os resultados apontam uma heterogeneidade de trajetórias prévias e posteriores de mudança do Ensino Médio no Brasil, demonstrando que há vários sentidos de mudança em curso e também que a aprovação da reforma tem um impacto importante na alteração das trajetórias das iniciativas estaduais. Nessa perspectiva, o artigo contribui, entre outros aspectos, para a compreensão das relações que se estabelecem entre os estados e o Governo Federal, em contextos federativos que compartilham competências relacionadas com a política da reforma do Ensino Médio.

Embora as autoras mencionadas não identifiquem nominalmente os estados, a análise que realizamos sobre a política educacional para o Ensino Médio do estado do Mato Grosso sugere que as mudanças prévias e a própria reforma vêm acontecendo majoritariamente por indução e incentivo do Governo Federal. Nesse estado, o MEC não apenas tem conseguido colocar na agenda educacional o tema da reforma, mas também pode direcionar esta agenda por meio de iniciativas relacionadas: i. ao Programa de Fomento às Escolas de Ensino Médio em Tempo Integral (EMTI), com início em 2008 e que se faz presente em 39 escolas chamadas Escolas Plenas que reorganizaram sua matriz curricular para abranger a parte diversificada do currículo, além de contemplar iniciativas relacionadas com estudo orientado, projeto de vida, integração de disciplinas e eletividade; ii. ao Ensino Médio Inovador (ProEMI), que está presente em 54 escolas e teve início em 2010 com foco no trabalho interdisciplinar e no aumento da carga horária; e, por último, iii. à Base Nacional Comum Curricular (BNCC).

Mato Grosso faz, assim, parte do grupo de 12 estados, segundo estudo de Lotta e Bauer (2018), com poucas iniciativas prévias de mudança no ensino médio. Com a chegada da reforma a esses contextos, essas iniciativas são impactadas de maneira proporcional aos investimentos da reforma se os estados aderirem aos incentivos federais. As mudanças atualmente existentes no Ensino Médio desse grupo de estados são aquelas propostas e induzidas pelo Governo Federal. Isso expressa o tipo de relações federativas que se estabelecem quando se trata de estados em que há menor presença de conteúdos próprios de mudança e essas 
mudanças são mais aderentes ao proposto pelo Governo Federal, o que faz com que a trajetória da reforma seja mais linear e previsível (LOTTA ET AL, 2019, p. 18).

Em conjunto, as análises de documentos e das entrevistas ajudam a entender porque a reforma do Ensino Médio mato-grossense segue um percurso de natureza mais incremental e experimental e porque a dependência estadual do apoio técnico e financeiro do Governo Federal tende a colocar o ritmo da reforma em compasso com as iniciativas do MEC. Concomitantemente, colabora para o entendimento do porque a governança externa para a implementação da reforma conta com atores não estatais, entre os que se destaca o $\operatorname{CONSED}^{20}$ e seu papel nas iniciativas de mudança do estado do Mato Grosso, particularmente nas relativas à mudança curricular do Ensino Médio, ao menos na fase de implementação investigada.

De acordo com as entrevistas, frente à inércia do MEC o terceiro setor se tornou o protagonista na proposição e apoio às redes de educação para a implementação da reforma, e esse protagonismo teria sido reforçado pela situação de isolamento social decorrente da pandemia provocada pelo COVID-19. As entrevistas ressaltam que a última orientação do MEC para o estado foi dada em 2019.

Assim a adesão pelo estado aos programas de fomento do MEC e a ausência de coordenação e incentivo do Governo Federal no período mais recente não propiciaram apenas um contexto experimental de implementação das principais dimensões do Novo Ensino Médio, como o currículo e o tempo integral, mas também estimularam novas parcerias, principalmente a partir de 2016, com diversas organizações não governamentais, que orientam a implementação da reforma pelo estado. Segundo estudo coordenado por Lotta e Bauer (2018), a rede estadual do Mato Grosso mantém parcerias com o Instituto Unibanco ${ }^{21}$ e o Instituto de Corresponsabilidade pela Educação - $\mathrm{ICE}^{22}$, que atuam na formação inicial das

\footnotetext{
${ }^{20}$ O CONSED, Conselho Nacional de Secretários de Educação, é uma associação de direito privado, sem fins lucrativos, que reúne as Secretarias de Educação dos Estados e do Distrito Federal, que tem como objetivo promover a integração das redes estaduais de educação e intensificar a participação dos estados nos processos decisórios das políticas nacionais, além de promover o regime de colaboração entre as unidades federativas para o desenvolvimento da escola pública

${ }^{21}$ É uma das instituições responsáveis pelo investimento social privado do Itaú Unibanco. Suas ações são voltadas para a educação, com foco no Ensino Médio.

${ }^{22} \mathrm{O}$ Instituto de Corresponsabilidade pela Educação - ICE, é uma entidade sem fins econômicos, foi criado em 2003 por um grupo de empresários. O instituto se localiza em Recife.
} 
equipes de implementação e na formação de professores e, também, com o Instituto Sonho Grande e com o Instituto Natura, que participam dos comitês decisórios e são financiadores, além do Instituto Natura se envolver também em questões gerenciais do programa (LOTTA e BAUER, 2018 p. 69).

Na dimensão curricular, o estado do Mato Grosso utilizou o material sobre a BNCC elaborado pelo Instituto Reúna ${ }^{23}$ como fonte de consulta para a construção do documento de referência do estado, e há menção ao uso de materiais do Instituto Porvir $^{24}$ e da Fundação Lemann ${ }^{25}$ pela rede. Segundo os entrevistados, entre os programas do Governo Federal ativos está o repasse do $\mathrm{PDDE}^{26}$ e também o ProBNCC que teria se tornado um dos programas mais relevantes, embora haja problemas com os pagamentos previstos pelo Programa para as equipes.

A relação com o Conselho Estadual de Educação, apesar das tensões em torno do alinhamento das proposições sobre a implementação da reforma, é positiva, sendo inclusive o Conselho parte do Comitê de Acompanhamento da Implementação do Novo Ensino Médio.

As redes municipais também possuem representantes no Comitê de Acompanhamento da Implementação do Novo Ensino Médio e foi aplicado um questionário aos estudantes dos anos finais do fundamental para incluí-los na discussão acerca da reforma do ensino médio.

As entrevistas realizadas mostram que os agentes da SEE-MT consideram fundamental o papel desempenhado pelo CONSED junto ao estado, em razão da orientação que essa organização presta à SEE-MT na implementação da reforma, num contexto de forte deslegitimação do MEC nos estados.

\footnotetext{
${ }^{23}$ O Instituto Reúna é uma organização sem fins lucrativos que nasceu a partir do atual desafio da implementação da Base Nacional Comum Curricular (BNCC) e para cumprir a Meta 7 do Plano Nacional de Educação, que prevê o fomento à qualidade da educação básica em todas as etapas e modalidades. O instituto possui como parceiros a Fundação Lemann e Imaginable Futures.

24 O Porvir é uma organização autônoma e sem fins lucrativos, que possui uma plataforma de conteúdos e mobilização sobre inovações educacionais do Brasil. Até o ano de 2019 era mantido pelo Instituto Inspirare.

25 A fundação Lemann é uma organização familiar e sem fins lucrativos que colabora com iniciativas para a educação pública em todo o Brasil.

${ }^{26}$ O Programa Dinheiro Direto na Escola (PDDE) tem por finalidade prestar assistência financeira para as escolas, em caráter suplementar, a fim de contribuir para manutenção e melhoria da infraestrutura física e pedagógica, com consequente elevação do desempenho escolar. Também visa fortalecer a participação social e a autogestão escolar.
} 
A SEE-MT utilizou, inicialmente, o Guia de Implementação do MEC e a Portaria 649, que institui o Programa de Apoio ao Novo Ensino Médio e estabelece diretrizes, parâmetros e critérios para sua implementação. No entanto, os entrevistados sinalizam que muitas incertezas surgiram em relação à implementação da reforma, que o MEC não teria sido capaz de reduzir. Neste sentido, os entrevistados sinalizam sobre a falta de orientação pelo MEC e a desorganização presente nos poucos encontros de formação promovidos pelo Governo Federal, considerando que foram ações "extremamente desarticuladas".

O papel orientador foi desempenhado pelo CONSED, mediante a organização de espaços formativos e de troca que permitiram à SEE-MT compreender o processo de produção do documento de referência curricular do Ensino Médio.

Então o CONSED, ele está tendo um protagonismo intenso dentro desse processo de implementação. Então, assim, é o que tem fornecido formação para a coordenação geral, é o que tem dado formação para as coordenadoras de etapa. É o que tem dado orientações que a gente tem conseguido caminhar com um pouco mais de critérios, e mais tranquilidade também. É o CONSED que tem, de fato, facilitado o nosso trabalho. O Guia de implementação, lógico né, também nos orienta, mas é só o princípio... Eu penso que seja o passo inicial. O que tem desenvolvido bastante o nosso trabalho, que tem fornecido, assim, orientações precisas, um pouco mais precisas, é o CONSED. (GE2)

De acordo com o relato do GE1, o estado estava envolvido no processo de elaboração do documento de referência curricular para o Ensino Fundamental e, durante a realização de consultas às secretarias para o acompanhamento do processo, em eventos realizados pelo MEC e o CONSED, surgiu a informação de que a BNCC do Ensino Médio estava em processo de construção. Após esse momento, ocorreram algumas conferências promovidas pelo CONSED e, em concomitância, o MEC começou a distribuir materiais sobre a reforma. O CONSED assumiu um papel de dinamizador das informações do MEC junto à SEE-MT e iniciou-se a estruturação da equipe ProBNCC.

A participação do CONSED na implementação da reforma se dá por meio da Frente de Currículo e Novo Ensino Médio. A frente constitui uma das estratégias de trabalho da Agenda da Aprendizagem, que foi elaborada em regime de colaboração com a União dos Dirigentes Municipais de Educação (Undime) e reúne temas prioritários para estados e municípios. Por meio dessa Frente, o CONSED 
apoia os estados brasileiros na construção dos currículos e da arquitetura do Novo Ensino Médio (CONSED, 2020).

Considerando que são diversos os públicos impactados com as mudanças introduzidas pela reforma do ensino médio, a pesquisa também investigou os processos de articulação da secretaria com a comunidade escolar. As entrevistas sinalizam que houve iniciativas nesse sentido e que, em 2019, foram realizadas audiências com os estudantes, visitas para diálogo com as escolas piloto, rodas de conversa com os pais e a realização de um seminário. Nas entrevistas foi sinalizado que o diálogo com a comunidade escolar, além de ser uma prerrogativa da secretaria, se tornou uma necessidade, visto que existe uma grande cobrança dos sindicatos e das famílias em virtude da divulgação do Novo Ensino Médio pelo Governo Federal. A comunidade escolar cobra explicações sobre a reforma e existe um cenário de resistência e preocupação com essa mudança. O diálogo direto com professores e gestores, até o momento, ocorreu apenas com aqueles que fazem parte das escolas pilotos, e até o momento não pode ser estendido para os demais atores da rede.

No caso do novo currículo do Ensino Fundamental, o Conselho Estadual de Educação promoveu momentos de discussão, convidando professores de áreas, o que contribuiu, segundo os entrevistados, para um amadurecimento do debate com os professores da rede. Assim, o fato de ter mantido a mesma equipe para discussão do novo currículo do ensino médio incrementou o entendimento da progressão das competências e habilidades ao longo da educação básica, enquanto a discussão do Novo Ensino Médio com as escolas de tempo integral contribui mais especificamente para o entendimento da "estrutura dos itinerários", "do bloco de eletivas", "do projeto de vida" e "das trilhas de aprofundamento". Os entrevistados entendem que os itinerários formativos são determinados legalmente e dizem esperar que esses encontros os ajudem a conseguir "explicar a função do itinerário" e depois a "amadurecer a discussão geral com os professores da rede", reduzindo, assim, nos temos de Matland (1995), o grau de ambiguidade e de conflito em torno da política.

Até esse momento, a rede pautava seu currículo nos parâmetros curriculares e principalmente nas orientações curriculares de Mato Grosso, adotando a divisão 
curricular por componente disciplinar. O novo currículo para o Novo Ensino Médio dispõe, no artigo $3^{\circ}$, que "os currículos do ensino médio devem ser pautados na formação integral dos alunos, possibilitando uma formação no sentido da construção do projeto de vida deles e sua formação no aspecto físico, cognitivo e socioemocional (Lei $\mathrm{n}^{\circ}$ 13.415, de 16 de fevereiro de 2017.artigo 3, $\S 7^{\circ}$ )". Embora também em número discreto, em 39 unidades, desde 2016 a rede possui, como vimos, experiência de escolas integrais, com currículos flexíveis, disciplinas eletivas e projeto de vida.

Em síntese, as falas ressaltam a importância do CONSED na articulação junto aos estados para estruturação do currículo do Ensino Fundamental, no repasse de informações sobre a chegada da reforma do ensino médio e no apoio às primeiras ações para a organização da secretaria com vistas à implementação do Novo Ensino Médio.

Do ponto de vista das relações multiníveis (HILL e HUPE, 2003), as mudanças que a reforma do Ensino Médio traz para a governança interna das Secretarias Estaduais de Educação parecem ser grandes e significativas e conduzem o foco da pesquisa para o entendimento da organização interna da SEE-MT e para suas relações com a rede para a implementação do Novo Ensino Médio.

A SEE-MT é dividida em cinco níveis administrativos, a coordenadoria de desenvolvimento do ensino médio está dentro do quinto nível, que é o nível de execução programática. Dentro deste nível existem 6 superintendências, a saber: 1 . Superintendência de Políticas de Educação Básica; 2. Superintendência de Políticas de Diversidades Educacionais; 3. Superintendência de Políticas de Desenvolvimento Profissional; 4. Superintendência de Políticas de Gestão Escolar; 5. Núcleo Estratégico de Apoio e Monitoramento das Assessorias Pedagógicas; 6. Superintendência de Infraestrutura Escolar (DECRETO No 161, de julho de 2019). As entrevistas apontam que as superintendências de Políticas de Educação Básica e de Políticas de Gestão Escolar são as que estão mais à frente da reforma no estado.

Neste contexto, foi montado um Comitê de Acompanhamento da Implementação do Novo Ensino Médio, composto por um grupo diverso que contempla representantes da própria secretaria, de outras secretarias, de universidades, de sindicatos, do conselho estadual de educação, compondo um 
grupo intersetorial e interinstitucional. As discussões sobre a reforma são iniciadas dentro da Coordenadoria de Desenvolvimento do Ensino Médio, a partir de um Grupo de Trabalho (GT) criado na própria coordenadoria, passam pelo grupo do ProBNCC e depois são encaminhadas para o Comitê de Acompanhamento da Implementação do Novo Ensino Médio, que é presidido pela secretária de Educação e possui papel deliberativo. As discussões realizadas pelo GT possuem uma pauta voltada para as escolas pilotos da rede. Assim, os mesmos atores participam do Comitê de Acompanhamento, no grupo de trabalho e fazem parte do ProBNCC.

As entrevistas revelam que não houve uma reestruturação organizacional da rede para a implementação da reforma, mas sim a articulação entre as superintendências para o desenho do processo de implementação. Ficou claro que não é do conhecimento dos entrevistados a previsão de alguma reestruturação futura. As entrevistas evidenciam, aliás, um cenário contrário à ampliação da equipe, mais precisamente revelam que houve uma diminuição no número de funcionários devido a cortes financeiros no estado.

O acompanhamento das escolas é realizado pelas assessorias pedagógicas, que, segundo as entrevistas, também não sofreram nenhuma reestruturação. Os CEFAPROS, que são os centros de formação, também não foram reestruturados em função da reforma, mas teriam voltado suas ações formativas para a BNCC. Também não foi realizada e não está prevista a ampliação ou reestruturação do quadro de professores, apesar da necessidade de contratação e de diversificação docentes colocadas pelo Novo Ensino Médio.

Os documentos e entrevistas também evidenciam que a articulação com a rede municipal para implementação do Novo Ensino Médio ainda não está na agenda da SEE-MT, mesmo envolvendo temas relevantes como o transporte escolar, por exemplo. (LOTTA e BAUER, 2018). Além disso, as interações da SEE-MT com os professores têm se limitado àqueles que atuam nas chamadas Escolas Plenas.

À luz dos estudos de Hupe e Hill (2003) sobre camadas federativas e níveis burocráticos, esta seção evidenciou a complexa relação presente no contexto de implementação da reforma do ensino médio no estado do Mato Grosso. Destaca-se que a política foi formulada pelo Governo Federal, mas, em virtude do vácuo 
institucional provocado pela falta de coordenação da reforma pelo Governo Federal, a mesma acabou por acontecer no estado por meio da relação estabelecida com o terceiro setor, notadamente com o CONSED, que ganha um papel de grande importância no cenário. A seção apresentou também as relações entre a coordenadoria de educação e as escolas, revelando um cenário com grandes desafios que envolvem a falta de recursos estaduais para o acompanhamento de todas as unidades e a centralidade dos diálogos com as escolas piloto.

\section{2 - Incrementalismo e experimentalismo na reforma mato-grossense}

Em termos de iniciativas prévias de mudança no Ensino Médio, como vimos na seção acima, a rede estadual do Mato Grosso possuía, antes da chegada da reforma, projetos de ampliação da carga horária e de educação integral no Ensino Médio, induzidos pelo Governo Federal. Com efeito, desde 2008, a rede estadual promove iniciativas de mudança no Ensino Médio de maneira experimental e incremental, essas mudanças são induzidas pelo MEC e guardam sintonia com os principais eixos do Novo Ensino Médio. À luz dos estudos de Lindblom (1979), verifica-se que a implementação da política dá prioridade a dimensões da reforma que se mostram melhor sintonizadas com iniciativas prévias que estão em curso no estado do Mato Grosso. Isto é, as mudanças no ensino médio estadual não se iniciam do zero, mas acontecem por meio de decisões incrementais que não geram mudanças drásticas no cenário estadual. Programas do Governo Federal envolvendo incentivos financeiros, como o Programa de Fomento às Escolas de Ensino Médio em Tempo Integral (EMTI) chamadas no estado de Escolas Plenas, existem desde 2008, e o Ensino Médio Inovador (ProEMI), com adesão do estado em 2010, são evidências do quanto a agenda da reforma foi pautada pelo Governo Federal no período passado. Trata-se também de programas que se expandem lentamente, acontecem em um número restrito de escolas piloto, apresentam baixo nível de conflito, visto que não há questionamento sobre a sua necessidade no estado, e apresentam, em função da falta de coordenação do MEC, alto nível de ambiguidade, caracterizando um contexto experimental de implementação (MATLAND, 1995). As Escolas Plenas, são, na verdade, o nome dado pelo estado às escolas que fazem parte do Programa de Fomento às Escolas de Ensino Médio 
em Tempo Integral- EMTI do MEC. Este é o programa que mais se aproxima da proposta de ampliação da carga horária e de formação integral apresentada pela reforma, embora sua oferta aconteça nos mais de dez anos de existência em um pequeno número das 490 escolas da rede. Segundo um dos entrevistados,

\begin{abstract}
Nós começamos com sete, depois catorze, mas não foi para além disso. Aí você pensa na dimensão de estado, em termos de Mato Grosso, quatrocentas e poucas unidades escolares, e aí como é que você fica apenas com um número reduzido, com boas experiências, bons resultados, porém não ampliado para que todos tivessem a possibilidade de frequentar, participar de uma unidade que tivesse esse tipo de organização. (GE2)
\end{abstract}

As entrevistas indicam que a falta de ampliação do programa acontece em virtude da limitação de recursos do estado. A seleção das escolas para o programa também esbarrou nos limites orçamentários da rede. Assim, a escolha das escolas para sediar o projeto seguiu, inicialmente, o critério de proximidade das unidades escolares com a sede da Secretaria Estadual de Educação, de modo a facilitar o deslocamento da equipe da coordenadoria para o acompanhamento das ações de implementação. Após a aplicação desse primeiro critério, a implementação seguiu os critérios estabelecidos pelo Programa de Apoio ao Novo Ensino Médio do MEC, a saber:

b) unidades escolares que se enquadrem em uma ou mais das categorias a seguir:

1. participantes do Programa Ensino Médio Inovador - ProEMI, instituído pela Portaria MEC no 971, de 9 de outubro de 2009;

2. unidades escolares de ensino médio em tempo integral, de iniciativa estadual ou distrital, não participantes do Programa de Fomento à Implementação de Escolas de Ensino Médio em Tempo Integral; e

3. unidades escolares que já possuam jornada diária de cinco horas.

II - oferta de currículos contemplando, no mínimo, dois itinerários formativos, descritos no art. 36 da Lei $n^{\circ}$ 9.394, de 1996. (MEC. Portaria 649, Capítulo IV, 2018)

A secretaria realizou visitas às unidades escolares para a apresentação da proposta, para ouvir a comunidade e identificar seu interesse em participar do programa, procurando mobilizar um processo de adesão. As escolas finalmente 
selecionadas para serem pioneiras na implementação do Novo Ensino Médio como escolas piloto estão localizadas no entorno da SEE-MT e o motivo invocado para justificar essa localização se relaciona com a carência de recursos financeiros para o acompanhamento e monitoramento de unidades escolares situadas em territórios distantes. Com essa localização espacial das unidades que implementam o Novo Ensino Médio, escolas da periferia, escolas rurais, quilombolas e indígenas, que tendem a serem as mais vulneráveis socialmente, não têm praticamente chance de vir a fazer parte dessa experiência piloto de tempo integral ou de uma possível expansão.

Em 2019, a SEE-MT acompanhou as unidades escolares que faziam parte do piloto, incentivando a elaboração da proposta de flexibilização curricular. Como poucas escolas tinham experiência com essa iniciativa, a secretaria realizou encontros de integração entre as unidades escolares para troca de experiências e compreensão da proposta. A proposta era que a flexibilização curricular teria inicio em 2019, mas devido aos entraves do MEC foi adiado para 2020, o que foi considerado positivo para a rede, pois "se teve mais tempo para entender melhor a proposta e para orientar os profissionais da educação”, evidenciando o grau de ambiguidade da política. Em 2020, a rede já iniciou a implementação da proposta de flexibilização curricular entre as escolas piloto.

A porcentagem de escolas piloto na rede é pequena (12\%) e as mesmas nasceram com caráter experimental e forte indução do MEC. As entrevistas evidenciam que o número de escolas foi definido propositalmente pela secretaria, pois o fomento do Governo Federal para as escolas pilotos existiria apenas no período de implementação da reforma. Os atores entrevistados relatam a preocupação com relação à sustentabilidade desse modelo na rede e justificam em razão disso o pequeno número de escolas participantes do piloto. Essa preocupação é alimentada pela própria instabilidade do Governo Federal e do MEC, pela possibilidade sempre presente de troca do ministro da Educação e pela interrupção das ações do MEC de fomento e coordenação. As entrevistam evidenciam que a rede não vê a reforma do Ensino Médio como uma política pública, mas sim como um programa do MEC, considerando a possibilidade de não ter continuidade. 
Entre as iniciativas prévias de mudança existentes no estado, induzidas e incentivadas pelo Governo Federal, um dos entrevistados fez referência ao Programa Ensino Médio Inovador (EMI): "nós tínhamos também o Programa Ensino Médio Inovador aqui no estado, que na verdade ele era um fomentador dessa mudança" (GE3). O mesmo entrevistado afirma que a chegada da reforma impactou a rede significativamente, mas ressaltou que a reforma também ajudou a mostrar que "o nosso estado já possui algo nesse movimento", referindo-se à iniciativa de escolas em tempo integral que acontece de maneira experimental na rede.

Com efeito, na chegada da reforma, existiam em torno de 60 (sessenta) unidades escolares que ofertavam o programa do EMI e sua oferta teria contribuído, segundo os entrevistados, para a compreensão das mudanças definidas pela nova política da reforma, principalmente no que tange à flexibilização curricular. Vale ressaltar, mais uma vez, que, considerando o tamanho da rede, o número de escolas que ofertam o EMI atinge um percentual muito pequeno, aproximadamente $12 \%$ da rede, o que faz com que o processo de compreensão e implementação da política em toda a rede seja ainda tido como um dos grandes desafios pelos membros da SEE-MT entrevistados.

Também há registro de iniciativas de formação integral, como a integração de disciplinas, a eletividade, o projeto de vida e os estudos orientados, que, em 2018, incidiam apenas em cerca de $8 \%$ da rede (LOTTA e BAUER, 2018, p. 69)

A capacidade orçamentária estadual também foi colocada pelos entrevistados como um desafio para o Mato Grosso, pois a reforma incorpora a ampliação da carga horária anual e a criação dos itinerários formativos, que geram novas demandas de infraestrutura e de contratação de profissionais para atuarem nas escolas e na própria secretaria.

O processo de formação continuada dos profissionais também é um desafio para a rede de ensino, que se mostra dependente do apoio do Governo Federal. A formação continuada está na agenda da secretaria de Mato Grosso, que elaborou um plano de formação com foco nos profissionais das escolas piloto e cuja continuidade depende do repasse previsto de um milhão e oitocentos mil reais pelo Governo Federal. Já houve a formação inicial para as Escolas Plenas, no contexto 
da implementação da formação integral, e foi durante essa experiência que os CEFAPROS tiveram contato com as novas metodologias da formação integral.

A previsão dos entrevistados é que as atividades de formação sejam retomadas de forma ampliada logo após a homologação do documento de referência curricular para o Ensino Médio. O plano de formação, em termos da formação dos formadores, está sob responsabilidade dos 15 Centros de Formação e Atualização Profissional (CEFAPROS) que a SEE-MT mantém distribuídos pelo estado, e prevê a multiplicação da formação para diretores, coordenadores e professores da rede estadual.

As entrevistas revelaram, ainda, que a reforma se beneficiou de iniciativas prévias de mudança curricular já existentes no Ensino Fundamental, uma vez que a definição do novo currículo do Ensino Médio contou com as mesmas equipes técnicas e também com o apoio do CONSED. Além do CONSED, a rede estadual de ensino de Mato Grosso mantém parcerias com outras organizações do terceiro setor, tais como Instituto Unibanco, ICE, Instituto Sonho Grande ${ }^{27}$ e Instituto $\mathrm{Natura}^{28}$, que apoiam a formação inicial das equipes de implementação e a formação de professores, participam de comitês decisórios e no financiamento (LOTTA e BAUER, 2018, p. 69).

Com efeito, ainda na perspectiva incremental está a implementação da dimensão curricular da reforma, talvez a que mais tenha avançado no período mais recente. Isso se deve, segundo os entrevistados, à experiência acumulada pela equipe da SEE-MT e colaboradores com o processo de reformulação do currículo do Ensino Fundamental para adequá-lo à BNCC. De fato, as entrevistas dão conta de que a mesma coordenação estadual e os mesmos redatores e colaboradores que formaram a equipe responsável pelo novo currículo do Ensino Fundamental permaneceram vinculados à secretaria estadual colaborando com a construção do novo documento de referência curricular para o Novo Ensino Médio. Segundo as entrevistas, o estado não conta com o apoio do Governo Federal na reformulação

27 O Instituto Sonho Grande é uma organização não governamental que possui ações voltadas para a melhoria da Educação Básica.

28 O Instituto Natura é uma Organização da Sociedade Civil de Interesse Público que atua na área da Educação, apoiando iniciativas para professores, escolas, gestores públicos e Consultoras de Beleza Natura. É o braço social da Natura. 
do currículo e na implementação da reforma, tendo o apoio de um analista de gestão contratado pelo CONSED para atuar junto à secretaria estadual na construção do processo de consulta pública do novo currículo, que envolve tanto a proposta de formação geral quanto os itinerários formativos.

Segundo os entrevistados, foram realizadas três consultas públicas por meio do canal da SEE- MT na Internet. A primeira consulta teve como ponto norteador o documento de referência curricular MT/Ensino Médio e ficou disponível de 25 de setembro de 2019 até 03 de abril de 2020; essa consulta, segundo um dos entrevistados, praticamente não teve participação dos professores. A segunda consulta pública teve como ponto norteador a arquitetura da reforma e o currículo do Ensino Médio e ficou disponível do dia 09 de dezembro de 2019 até 23 de abril de 2020. Nessa etapa, foi considerada "razoável” a participação docente. A terceira consulta pública tem como norte o currículo do Ensino Médio - itinerários formativos e arquitetura, e estará disponível entre 13 de maio e 26 de junho de 2020. Pelo cronograma da SEE-MT, o encaminhamento da versão final do documento para o Conselho Estadual de Educação ${ }^{29}$ seria realizado, inicialmente, no mês de abril, embora todas as atividades e contatos presenciais entre o Conselho e o MEC tenham sido suspensos por causa da pandemia provocada pelo COVID-19, o que leva os entrevistados a avaliarem que essa suspensão limitará as possibilidades de apreciação da matéria pelos conselheiros.

Ainda em relação à dimensão curricular da reforma, os entrevistados reconhecem que o itinerário técnico-profissional é o menos definido até o momento e sinalizam para a falta de estrutura das escolas da rede para adotá-lo. Eles apontam a busca de aproximação com a SEE-MT por parte da Universidade Estadual de Mato Grosso - UNEMAT e do Sistema $\mathrm{S}^{30}$, no sentido de desenvolver alguma parceria em torno do quinto itinerário, mas reconhecem que essa aproximação esbarra na falta de recursos financeiros da pasta. Adotando uma perspectiva incremental (LINDBLOM, 1979), no qual a implementação de políticas tende a dar prioridade àquelas dimensões que estão em maior sintonia com ações anteriores ou

\footnotetext{
${ }^{29}$ O Comitê Estadual de Educação tem representação da Universidade, dos Institutos Federais, sindicatos, sindicatos das escolas particulares. A presidente do Comitê é a secretária de Estado de Educação e a vice-presidente a secretária adjunta de Políticas Ocupacionais.

${ }^{30}$ Sistema S é o conjunto de nove instituições de interesse de categorias profissionais, estabelecidas pela Constituição brasileira.
} 
em curso, a implementação do quinto itinerário formativo é vista pelos entrevistados como viável apenas em algumas das escolas que já oferecem o ensino médio integrado à formação profissional.

O novo currículo é reconhecido como o produto principal do impacto da reforma na rede estadual de ensino. Em linha com as experiências curriculares anteriores, os entrevistados registram uma preocupação relacionada mais ao Enem do que à BNCC, "está todo mundo apreensivo porque o Enem vai mudar, o Enem está se adequando à reforma do Ensino Médio, mas não existe um alinhamento muito conciso no momento entre o INEP e esse processo como um todo" (GE1). Essa fala evidencia novamente a ambiguidade que marca o processo de implementação da reforma no estado.

A relação currículo do ensino médio-avaliação é historicamente uma relação invertida. O Enem, assim como o vestibular nas Instituições de Ensino Superior, se constituiu ao longo do tempo como um fator associado à organização do currículo do Ensino Médio, representando assim uma referência importante na escolha e dosagem de saberes escolares nesse nível educacional. A fala do entrevistado faz menção à preocupação acerca da instabilidade na mudança do currículo orientada pela BNCC e pelo Novo Ensino Médio, que, na sua percepção, dependerá do ajuste do Enem à reforma: "o Enem muda, mas o Enem vai mudar com o currículo ditando o que o Enem vai mudar, ou o Enem vai mudar e os currículos vão ter que ser readequados novamente?" (GE1).

Os gestores da secretaria entrevistados não consideram que as avaliações externas devam moldar os currículos, mas existe uma grande preocupação entre eles em compreender em que grau o currículo proposto pela reforma estará representado na avaliação. Também em função da relação invertida existente entre o currículo do Ensino Médio e a avaliação em larga escala, os entrevistados manifestaram receio de que o Novo $\mathrm{Saeb}^{31}$ que está sendo noticiado pelo Inep acabe por inviabilizar a

31 O Inep anunciou que, os estudantes do ensino médio terão, a partir de 2021, uma nova oportunidade de ingressar na educação superior, por meio do novo Sistema de Avaliação da Educação Básica (Saeb). A reformulação do Saeb prevê que todos os anos e séries da educação básica, das escolas públicas e privadas, serão avaliados anualmente, em todas as áreas de conhecimento. Até o ano passado, a aplicação era a cada dois anos, para os alunos do $2^{\circ}, 5^{\circ}$ e $9^{\circ}$ anos do ensino fundamental e da $3^{\mathrm{a}}$ série do ensino médio, com provas de língua portuguesa e matemática. A meta é que todas as áreas de conhecimento sejam aferidas no Novo Saeb. As mudanças serão 
reforma, principalmente no componente "itinerários formativos". Novamente a ambiguidade marcando o processo de implementação na rede estadual e criando um cenário de incertezas.

De acordo com as entrevistas, a rede possui três propostas de desenho de flexibilização curricular que foram construídas por um comitê estadual com a participação de universidades e da comunidade escolar por meio das consultas públicas realizadas. Os agentes implementadores entendem que a existência dessas proposições mostra que o estado está avançado nos subsídios para definição do desenho de flexibilização curricular, e afirmam que essa definição deverá será tomada após a finalização do referencial curricular do estado.

A ampliação da carga horária também é identificada como um dos grandes desafios da rede e essa seria, na visão dos entrevistados, principalmente uma decisão de governo. Atualmente não existe um plano que contemple essa ampliação, mas apenas um modelo implementado pela secretaria em caráter experimental. A proposta é que seja iniciada, em 2021, a proposta de flexibilização curricular nas escolas piloto, mas os entrevistados declararam não existirem perspectivas de ampliação da participação do número de escolas, para além das existentes.

Outra preocupação presente nas entrevistas retoma a insistência no cenário de descrédito quanto à efetivação da própria BNCC

A não ser que a Base não seja mais uma política pública e aí você tem a desconstrução de todo um processo, aí esse documento não vai ter validade nenhuma aí, enfim, não vai ter nenhum momento de cobrança da implementação dessa nova arquitetura (GE1).

implementadas, de forma gradual, nos próximos cinco anos. Também foi anunciado pelo Inep a implementação do Enem seriado em 2021. A primeira novidade é a aplicação dos testes, no ano que vem, para os estudantes da $1^{\mathrm{a}}$ série do ensino médio. Com os resultados obtidos a cada ano, será possível avaliar a escola e o desempenho do aluno para o ingresso na educação superior. A proposta para avaliação seriada dos estudantes em cada ano letivo será uma alternativa ao Exame Nacional do Ensino Médio (Enem). 
A fala remete ao documento de referência curricular para o Ensino Médio que está em construção na coordenadoria e evidencia o cenário de incerteza criado pelo Governo Federal.

Com relação aos itinerários formativos, a SEE-MT aguarda a elaboração do diagnóstico das capacidades da rede e definições do Conselho Estadual para decisão sobre quais desses itinerários serão incorporados às escolas pelo estado. A rede, no entanto, possui duas proposições em termos de estrutura do documento, que propõem dois itinerários diferenciados, a saber: a) um itinerário com uma trilha de aprofundamento dentro de uma área do conhecimento, mais um itinerário integrado; e b) um itinerário com várias áreas do conhecimento compondo uma trilha de aprofundamento. O itinerário integrado é o que possui mais força na rede, pois garante uma diversidade de conhecimentos para os estudantes.

Muitas das mudanças realizadas nas redes vêm acompanhadas pela criação de novos atos normativos, como instrução normativa, edital, portaria ou lei. No entanto, mesmo iniciativas mais institucionalizadas, como o planejamento do sistema de matrícula e o sistema de certificação, não foram implementados até o momento.

\section{3 - Contexto de implementação do Novo Ensino Médio: ambiguidade e conflito}

Há uma preocupação evidente entre os entrevistados com a recepção de escolas e professores da proposta do novo currículo e do Novo Ensino Médio e com as incertezas e os conflitos que a divulgação ampliada dessa política pode continuar a suscitar. Ambiguidade e conflito marcam desde o início a relação entre a rede de ensino estadual e a reforma do MEC.

No início, a chegada da reforma do Ensino Médio no estado foi vista pelos agentes implementadores da SEE-MT como uma ação necessária em função dos desafios enfrentados pela rede estadual nessa etapa da Educação Básica.

No entanto, as entrevistas evidenciam que, também, com a chegada da reforma no estado criou-se um clima de descrédito em relação à implementação do 
Novo Ensino Médio na rede, tanto entre as altas burocracias educacionais quanto na comunidade escolar, gerando conflitos e baixas expectativas de execução.

Ao chegar à secretaria, a possibilidade de implementação da reforma na rede de ensino estadual foi recebida com descrédito pelos gestores. Isso pode ser explicado pela inação e falta de continuidade na coordenação da reforma e da BNCC pelo MEC e também porque a reforma se movimenta há tempos em um cenário que é também herdeiro dos conflitos suscitados pelo lançamento dessa política. Lembremos que, em 2016, foi promulgada a Medida Provisória da reforma do Ensino Médio e isso gerou um clima de conflito que não foi removido mesmo com a aprovação da lei ${ }^{\circ} 13.415$, no ano seguinte, fazendo com que sua legitimação pelos estados ainda seja um tema em aberto.

Em razão disso, não é difícil compreender que a reação inicial da SEE-MT e dos professores tenha sido a de acreditar que a reforma ainda sofreria modificações, e mesmo que ela não chegaria a ser implementada. De acordo com um dos entrevistados "apenas no início de 2020 a secretaria começou realmente a acreditar que a política seria executada” (GE3). Esse sentimento, no entanto, está ainda presente, principalmente com relação ao novo currículo, aos itinerários formativos e à expansão das escolas de tempo integral.

As entrevistas fazem referência também a um alto grau de conflito dos professores e do sindicato com relação à reforma, embora esse conflito seja justificado nas entrevistas como parte de uma incompreensão da política, que estaria sendo superada com ações iniciadas em 2020 pela secretaria para mobilização e confirmação da implementação da reforma. De qualquer forma, as entrevistas mostram que, entre os desafios postos pela chegada da nova política para o Ensino Médio no estado, ainda está a formação do professor, já que se trata de professor formado disciplinarmente que está sendo colocado vis a vis uma reforma que demanda um perfil docente interdisciplinar.

Os agentes da SEE-MT entrevistados avaliam, entretanto, que a chegada da reforma está promovendo um novo olhar para o Ensino Médio no estado e uma reflexão acerca da transição entre esse nível de ensino e os anos finais do Ensino Fundamental. Eles afirmam que a preocupação com a transição dos estudantes entre as etapas da educação básica é um dos "pontos defensáveis" da reforma. Em 
consonância com essa percepção, um dos entrevistados disse que "dentro da própria Secretaria aconteceu um movimento de mobilização em que as pessoas puderam entender melhor a proposta, entender as concepções que estão por trás e isso tem sido positivo dentro da Secretaria" (GE3), e afirma ter sido essa mudança de concepção a novidade mais relevante para a rede estadual de ensino. Essa fala do entrevistado está relacionada às ações realizadas pela secretaria para ampliação das reflexões acerca da reforma, ações que envolveram a comunidade escolar e que tiveram como efeito a diminuição do conflito na implementação da política.

Embora não tenha havido ampliação do quadro burocrático da SEE-MT e tampouco recursos do MEC para fazer face à reforma, os entrevistados apostam que a presença de professores na composição da equipe da secretaria responsável pela elaboração do documento orientador do estado é um potencial ganho na compreensão pedagógica e de gestão da política que poderá se refletir na construção do documento. Se a participação docente nessa construção pode potencializar a dimensão pedagógica do Novo Ensino Médio, há, no entanto, expectativas de que esse mesmo documento possa gerar conflitos futuros, principalmente quando gestores do alto escalão da secretaria tiverem ciência dos altos custos envolvidos, especialmente no caso do modelo de tempo integral, pelos investimentos em infraestrutura e em pessoal que ele acarreta.

Por fim, a entrevistas trouxeram dados importantes sobre o cenário no qual a reforma do ensino médio chega à rede mato-grossense de educação. Tais dados permitem identificar as ações prévias realizadas pela secretaria, as primeiras mudanças causadas com a chegada da nova política para o ensino médio e os principais desafios vivenciados pela rede. Essa análise se torna fundamental para a compreensão dos impactos que a reforma irá gerar em Mato Grosso, considerando que as políticas assumem diferentes contornos a depender do contexto em que são implementadas e da reação dos atores locais (LOTTA ET AL, 2009, p.19). 


\section{Considerações finais}

Este estudo focaliza as atuais políticas educacionais dirigidas ao Ensino Médio, mais especificamente a reforma do Ensino Médio e sua implementação no estado do Mato Grosso. O estado foi escolhido por duas razões. Por um lado, está o fato de o contexto de implementação do Novo Ensino Médio no estado do Mato Grosso guardar semelhanças com o contexto de implementação de cerca de metade dos estados brasileiros, segundo Lotta e colegas (2020), o que confere um maior interesse ao estudo desse contexto em um estado específico. Por outro lado, a escolha desse estado também se deve à falta de estudos sobre as políticas educacionais da Região Centro Oeste e, em especial, à limitada quantidade de estudos sobre o estado do Mato Grosso. Trata-se de um estado que apresenta os maiores desafios quando se consideram seus indicadores educacionais comparativamente aos outros estados da mesma Região.

O contexto específico de implementação da reforma no estado do Mato Grosso, as relações com o Governo Federal e com atores estatais e não estatais e as percepções de atores burocráticos envolvidos com a reforma foram analisados a partir do binômio ambiguidade-conflito de Matland (1995) e das relações entre camadas federativas e níveis burocráticos de Hupe e Hill (2003). Na medida em que o estado do Mato Grosso apresenta experiências prévias de mudança no Ensino Médio que incidem sobre o processo de implementação da reforma, dialogamos com a perspectiva incrementalista, para a qual as iniciativas prévias de mudança importam na implementação de reformas, porque os agentes tendem a priorizar dimensões da reforma que dêem continuidade a iniciativas anteriores ou em curso. (LINDBLOM, 1979).

Os objetivos da pesquisa são os seguintes:

- Compreender as relações federativas e burocráticas que se estabelecem na implementação da reforma do Ensino Médio no estado do Mato Grosso, considerando os atores estatais e não estatais. 
- Identificar o papel desempenhado por experiências prévias de mudança na configuração do contexto atual de implementação da reforma do Ensino Médio no estado do Mato Grosso.

Em termos de relações federativas, é evidente que o Governo Federal promoveu estratégias de indução e de incentivo que, no caso do estado de Mato Grosso e em pelo menos mais 11 estados brasileiros, se traduziram em mudanças prévias que vem sustentando parcialmente a reforma, principalmente em relação à proposta das escolas de tempo integral. Desde 2008, a rede estadual de ensino do Mato Grosso promove iniciativas de mudança no Ensino Médio de maneira experimental e incremental, que são induzidas pelo Governo Federal e têm correspondência com as mudanças do Novo Ensino Médio. Programas do Governo Federal envolvendo fomento, como o Programa de Fomento às Escolas de Ensino Médio em Tempo Integral (EMTI) ou Escolas Plenas, existente desde 2008, o Ensino Médio Inovador (ProEMI), com adesão do estado em 2010, são evidências do quanto a agenda da reforma é pautada pela coordenação do MEC e pelo ritmo do apoio que o Governo Federal é capaz de prestar aos estados.

Com a interrupção da interlocução do estado com o MEC desde 2019, e com uma série de incertezas em relação aos objetivos e meios propostos para a reforma do ensino médio, o contexto de implementação no estado reforçou sua configuração experimental. Poucas escolas, das 504 sob gestão do estado, têm sido escolhidas ao longo do tempo para participar das mudanças, 54 para receber o Pro-EMI e 39 para implementar o projeto de Escolas Plenas, enquanto outras iniciativas, como integração de disciplinas, eletividade, projeto de vida e os estudos orientados, têm presença em apenas $8 \%$ da rede estadual. Destaca-se que a falta de ampliação considera desafios relacionados à recursos estaduais para a sua ampliação e manutenção.

As redes municipais têm representantes no Comitê de Acompanhamento da Implementação do Novo Ensino Médio, mas a articulação do estado com os municípios para implementação do Novo Ensino Médio ainda não faz parte da agenda da SEE-MT, apesar de envolver temas relevantes como o transporte escolar.

Também as entrevistas deixam claro que as iniciativas de tempo integral operam numa perspectiva experimental e incrementalista, mediante a sua implementação 
em um número pequeno de escolas-piloto. Os entrevistados, no entanto, justificam essa abrangência em função da preocupação com a sustentabilidade da experiência, ao mesmo tempo em que reconhecem o Programa Ensino Médio Inovador "como um fomentador dessa mudança".

Na mesma perspectiva, a implementação do $5^{\circ}$ itinerário formativo foi vista pelos entrevistados como uma iniciativa viável apenas em algumas das escolas que já oferecem o ensino médio integrado à formação profissional.

A ausência de coordenação da reforma pelo MEC, especialmente a partir de 2019, e os receios do estado quanto à sua efetiva implementação e sustentabilidade, explicam o aumento da intensidade da participação do CONSED e de um número significativo de organizações do terceiro setor que atuam como parceiros na implementação da reforma, seja na formação das equipes de implementação e de professores, seja na participação em comitês decisórios, seja nas ações gerenciais da reforma, bem como no financiamento de ações de implementação. Os estudos de Hupe e Hill (2003) sobre as camadas federativas e níveis burocráticos contribuem para a compreensão da complexa relação multicamadas presente no contexto de implementação da política. A reforma do ensino médio foi formulada pelo Governo Federal, mas este não assume uma postura propositiva e próxima junto ao estado, o que acaba incentivando a relação do estado com a iniciativa privada e criando uma complexa rede de relações para a implementação da reforma.

O CONSED assumiu um papel de dinamizador das informações do MEC junto à SEE-MT e iniciou-se a estruturação da equipe ProBNCC, atuou na articulação junto aos estados para reestruturação do currículo do ensino fundamental, no repasse de informações sobre a chegada da reforma do ensino médio e no apoio às primeiras ações para a organização da secretaria em vistas à implementação do Novo Ensino Médio.

Também a implementação da dimensão curricular foi vista como tributária da experiência acumulada pela equipe da SEDUC-MT e colaboradores com o processo de reformulação do currículo do ensino fundamental para adequá-lo à BNCC. Foi essa mesma equipe que se responsabilizou pela construção do novo documento de referência curricular para o Novo Ensino Médio. Sem o apoio do Governo Federal, a SEE-MT contou com o apoio do CONSED, expresso na contratação de um 
analista de gestão para atuar junto à secretaria estadual na construção do processo de consulta pública do novo currículo, tanto da proposta de formação geral quanto dos itinerários formativos. Outras organizações do terceiro setor disponibilizaram materiais sobre a BNCC que serviram de referência para a elaboração do documento curricular do estado.

No caso do novo currículo do ensino médio, o fato de ter sido mantida na SEEMT a mesma equipe que tinha participado da elaboração do novo currículo do ensino fundamental teria alargado, segundo as entrevistas, o entendimento da progressão das competências e habilidades ao longo da educação básica, enquanto a discussão do Novo Ensino Médio com as escolas de tempo integral teria contribuído, mais especificamente, para o entendimento da "estrutura dos itinerários", "do bloco de eletivas", "do projeto de vida" e "das trilhas de aprofundamento".

Os entrevistados apostam que esses encontros possam ajudá-los a conseguir "explicar a função do itinerário" e depois a "amadurecer a discussão geral com os professores da rede", reduzindo, assim, nos temos de Matland (1995), o grau de ambiguidade e de conflito do contexto estadual de implementação da reforma.

Apesar de o novo currículo ser reconhecido como o principal produto da reforma, a questão aparece recoberta pela preocupação com a avaliação. As notícias de uma possível mudança do ENEM para adequá-lo à BNCC e da reformulação da avaliação em larga escala, com a introdução do Novo Saeb, agora censitário, anual e seriado, deixam “todo mundo apreensivo porque o Enem vai mudar, o Enem está se adequando à reforma do Ensino Médio, mas não existe um alinhamento muito conciso no momento" entre e o ENEM e a BNCC. Mais uma vez, a ambiguidade se faz presente no contexto de implementação da reforma no estado, criando um cenário de incerteza, apesar de não haver questionamento sobre a sua necessidade. Ressalta-se que a reforma tem origem em uma Medida Provisória que coloca em pauta uma série de conflitos que não foram removidos pela sua transformação em lei e incorporação na LDB. Os conflitos em torno da reforma atingiram os estados e na rede estadual do Mato Grosso foram sendo amenizados à medida em que espaços de diálogo foram estabelecidos pela secretaria com a comunidade escolar, levando, atualmente, a um cenário de maior compreensão e aceitação da proposta. 
Os gestores da secretaria entrevistados não consideram que as avaliações externas devam moldar os currículos, mas existe uma grande preocupação entre eles em conhecer em que grau o currículo proposto pela reforma estará representado ou não na avaliação.

A rede possui propostas de desenho de flexibilização curricular construídas por um comitê estadual com a participação de universidades e da comunidade escolar, por meio da realização de consultas públicas.

A ampliação da carga horária também é identificada como um grande desafio para a rede e como uma decisão de governo, já que a ampliação da carga horária em um número maior de escolas depende de recursos financeiros e da contratação de novos professores.

Não apenas o cenário de paralisação e de incerteza produzido pelo COVID-19 preocupa os entrevistados. Eles apontam também que a implementação da reforma acontece num cenário de descrédito quanto à efetivação da própria BNCC e à coordenação e ao apoio do MEC na implementação do Novo Ensino Médio. Esse descrédito é nutrido pelas incertezas surgidas no estado durante a fase inicial de implementação da reforma, que o MEC não teria sido capaz de reduzir. A falta de orientação dos estados pelo MEC e a desorganização que caracterizaram os poucos encontros de formação promovidos pelo Governo Federal, foram consideradas ações "extremamente desarticuladas".

A rede possui, no momento, duas proposições de itinerários formativos: i. um itinerário com uma trilha de aprofundamento dentro de uma área do conhecimento e um itinerário integrado; ii. um itinerário com várias áreas do conhecimento que compõem uma trilha de aprofundamento. O itinerário integrado é o que possui mais força na rede, pois garante uma diversidade de conhecimentos para os estudantes.

Os entrevistados reforçaram que a inércia do MEC e o protagonismo do terceiro setor, que tomou a frente na proposição e apoio às redes de educação foi reforçada com a pandemia provocada pelo COVID-19. A última orientação do MEC para o estado foi dada em 2019 e desde então o Consed se tornou a principal fonte de orientações. 
No entanto, segundo os entrevistados, os repasses do MEC relativos ao PDDE permanecem ativos, apesar dos atrasos, há previsão de apoio do MEC para a realização da avaliação de impacto das escolas de tempo integral, e o ProBNCC se tornou um dos programas mais relevantes para a rede.

Sobre as relações burocráticas ou de governança interna, a SEE-MT montou um comitê de acompanhamento da implementação da reforma, composto por representantes da própria secretaria, de outras secretarias, de universidades, de sindicatos, do Conselho Estadual de Educação, compondo um grupo intersetorial e interinstitucional. O comitê de acompanhamento da implementação da reforma é presidido pela secretária de Educação, possui um papel deliberativo e uma pauta voltada para as escolas pilotos da rede. Os mesmos atores que participam do comitê de acompanhamento estão no grupo de trabalho e fazem parte do ProBNCC.

Os CEFAPROS, que são os centros de formação, não sofreram reestruturação ou ampliação do seu quadro de funcionários, mas voltaram suas ações formativas para a BNCC.

Por fim, a pesquisa aponta que existia um cenário limitado de mudanças no estado do Mato Grosso anterior à chegada da reforma e que era induzido pelo Governo Federal. Essa forte dependência da indução do GF, somado ao baixo grau de normatização da política no estado, caracterizam um contexto experimental de implementação da reforma. A rede mato-grossense está experimentando mudanças, testando experiências, mas ainda não investiu no processo de institucionalização via marcos legais, o que aumenta o grau de ambiguidade da reforma. A pesquisa evidencia ainda que existem intenções de futuras mudanças que, no entanto, dependem dos aportes financeiros do Governo Federal. Há poucas iniciativas estatais prévias de mudança no Ensino Médio estadual mato-grossense e as que existem acontecem de maneira incremental, aos poucos, acompanhando a capacidade de indução e de incentivo do Governo Federal, a experiência acumulada e os investimentos prévios do estado. Neste contexto incremental, o estado do Mato Grosso acabou dando prioridade àquelas dimensões da reforma que se mostram mais bem sintonizadas com iniciativas já em curso e também mais aderentes às políticas e programas do Governo Federal. 
É importante considerar que a pesquisa analisa um período específico e inicial da implementação da reforma do Ensino Médio no estado do Mato Grosso, que envolve a elaboração do novo currículo, reconhecido pela rede como o produto principal do processo de implementação da reforma. Neste sentido, a pesquisa se configura como um estudo original, que abre caminhos para outros pesquisadores aprofundarem o estudo das implicações da reforma do Ensino Médio no estado do Mato Grosso. Estima-se também que a pesquisa seja vista como um convite para a realização de futuras pesquisas e estudos sobre a implementação de políticas públicas educacionais. 
Referências bibliográficas

\section{Documentos oficiais}

Ministério da Educação. Base Nacional Comum Curricular Ensino Médio. Brasília: MEC, Consed, Undime, 2018.

BRASIL. Decreto $\mathrm{n}^{\circ} 7.083$, de 27 de janeiro de 2010. Dispõe sobre o Programa Mais Educação. Brasília, DF. Jan 2010.

BRASIL. Lei de Diretrizes e Bases da Educação Nacional, n. 9.394/96 - 24 de dez. 1996. Estabelece as diretrizes e bases da educação nacional. Brasília, 1996. Disponível em: http://www.planalto.gov.br/ccivil_03/leis/19394.htm; acesso em $10 / 11 / 18$.

BRASIL. Lei $n^{\circ} 11.692$, de 10 de junho de 2018. Dispõe sobre o Programa Nacional de Inclusão de Jovens - Projovem, instituído pela Lei no 11.129, de 30 de junho de 2005; altera a Lei no 10.836, de 9 de janeiro de 2004; revoga dispositivos das Leis nos 9.608, de 18 de fevereiro de 1998, 10.748, de 22 de outubro de 2003, 10.940, de 27 de agosto de 2004, 11.129, de 30 de junho de 2005, e 11.180, de 23 de setembro de 2005; e dá outras providências. Brasília. Jun de 2018 .

BRASIL. Lei $\mathrm{n}^{\circ}$ 9.394, de 20 de dezembro de 1996. Estabelece as diretrizes e bases da educação nacional. Diário Oficial da União, Brasília, 23 de dezembro de 1996. Disponível em: http://www.planalto.gov.br/ccivil_03/leis/L9394.htm . Acesso em: 12 de novembro de 2018.

BRASIL. Portaria No 867, de 4 de julho de 2012. Institui o Pacto Nacional pela Alfabetização na Idade Certa e as ações do Pacto e define suas diretrizes gerais. Diário Oficial da União, 5 jul. 2012. 
BRASIL. Portaria $n^{\circ}$ 649, de 10 de Julho de 2018. Institui o Programa de Apoio ao Novo Ensino Médio e estabelece diretrizes, parâmetros e critérios para participação. Diário oficial, publicado em 11 de julho de 2018.

BRASIL. Presidência da República. lei No 13.415, De 16 de Fevereiro De 2017. Altera as Leis nos 9.394, de 20 de dezembro de 1996, que estabelece as diretrizes e bases da educação nacional, e 11.494, de 20 de junho 2007, que regulamenta o Fundo de Manutenção e Desenvolvimento da Educação Básica e de Valorização dos Profissionais da Educação, a Consolidação das Leis do Trabalho - CLT, aprovada pelo Decreto-Lei no 5.452, de 1o de maio de 1943, e o Decreto-Lei no 236, de 28 de fevereiro de 1967; revoga a Lei no11.161, de 5 de agosto de 2005; e institui a Política de Fomento à Implementação de Escolas de Ensino Médio em Tempo Integral. Disponível em: http://www.planalto.gov.br/ccivil_03/_ato20152018/2017/lei/113415.htm. Acessado em 10 de novembro de 2018.

Congresso Nacional, texto da ementa da Medida Provisória no 746, de 2016 https://www.congressonacional.leg.br/materias/medidas-provisorias//mpv/126992 acessado em 12 de nov. de 2018.

Decreto $\mathrm{n}^{\circ}$ 161. Dispõe sobre a estrutura organizacional da Secretaria de Estado de Educação - SEDUC, a redistribuição de cargos em comissão e funções de confiança. Mato Grosso, julho de 2019.

Instituto Brasileiro de Geografia e Estatística - IBGE. Nota Técnica Principais diferenças metodológicas entre as pesquisas PME, PNAD e PNAD Contínua. Rio de Janeiro. 2015.

Ministério da Educação. Avaliação nacional da alfabetização (ANA): documento básico. - Brasília: Instituto Nacional de Estudos e Pesquisas Educacionais Anísio Teixeira, 2013.

Ministério da Educação. Instituto Nacional de Estudos e Pesquisas Educacionais. Exame Nacional do Ensino Médio. ENEM - DOCUMENTO BÁSICO. Disponível em $\quad<\quad$ http://inep.gov.br/documents/ 186968/484421/Exame+Nacional+do+Ensino+M\%C3\%A9dio++ENEM++documento+b\%C3\%A1 sico/e2cf61a8-fd80-45b8-a36faf6940e56113?version=1.1> acesso em 01 de junho de 2019. 
Ministério da Educação. Novo Ensino Médio: perguntas e respostas http://portal.mec.gov.br/pet/30000-uncategorised/40361-novo-ensino-medioduvidas acessado em 19 de dezembro de 2018.

Ministério da Educação. Programa Ensino Médio Inovador Documento Orientador. Elaboração de Propostas de Redesenho Curricular. 2017.

Ministério da Educação. Secretaria de Educação Especial. Manual de Orientação: Programa de Implantação de Sala de Recursos Multifuncionais.2010.

SEE MT. Orientações Curriculares: Concepções para a Educação Básica. / Secretaria de Estado de Educação de Mato Grosso. Cuiabá: SEDUC-MT, 2010.

Sociedade Brasileira de Educação Comparada- SBEC. Ensino Médio: impasses e dilemas / Candido Alberto Gomes, Ivar César Oliveira de Vasconcelos, Silvia Regina dos Santos Coelho (Orgs.). Brasília: Cidade Gráfica Editora, 2018.

Portal do MEC. GESTAR II. Disponível em < http://portal.mec.gov.br/gestar-ii-> acessado em 01 de junho de 2019.

PORTAL MEC. Ensino Médio Inovador. Disponível em < http://portal.mec.gov.br/component/content/article?id=13439:ensino-medioinovador> acessado em 26 de maio de 2020.

PORTAL MEC. Investimentos proporcionam avanços da educação nas comunidades Quilombolas. Disponível em < http://www.mt.gov.br//investimentos-proporcionam-avancos-da-educacao-nas-comunidadesquilombolas> acessado em 26 de maio de 2020.

Portal do MEC. Programa Dinheiro Direto na Escola - PDDE. Disponível em < http://portal.mec.gov.br/financiamento-estadual/dinheiro-direto-na-escola> acessado em 30 de maio de 2019.

Agencia Senado. Sistema S. Disponível em: < https://www12.senado.leg.br/ noticias/glossario-legislativo/sistema-s>. Acesso em: 07 de maio de 2020. 


\section{Artigos e textos}

ARANHA, Ana Luiza \& FILGUEIRAS, Fernando. Instituições de accountability no Brasil: mudança institucional, incrementalismo e ecologia processual Brasília: Enap, 2016

ARAÚJO, Luísa e RODRIGUES, Maria de Lurdes, «Modelos de análise das políticas públicas », Sociologia, Problemas e Práticas [Online], 83|2017, posto online no dia 06 fevereiro 2017, consultado o 09 maio 2020. URL: http://journals.openedition.org/ spp/2662

ARRETCHE, Marta. Continuidades e descontinuidades da Federação brasileira: de como 1988 facilitou 1995. Dados, Rio de Janeiro, v.52, n 2, p. 377 423, 2009.

ARRETCHE, Marta. Democracia, federalismo e centralização no Brasil. Rio de Janeiro, Editora FGV/Editora Fiocruz, 2012, 232 p.

AUGUSTO, Cleiciele Albuquerque; SOUZA, José Paulo de; DELLAGNELO, Eloise Helena Livramento and CARIO, Silvio Antonio Ferraz. Pesquisa Qualitativa: rigor metodológico no tratamento da teoria dos custos de transação em artigos apresentados nos congressos da Sober (2007-2011). Rev. Econ. Sociol. Rural [online]. 2013, vol.51, n.4 [cited 2020-05-19], pp.745-764.

BALL, S. e AVELAR, M. Mapeando a nova filantropia e o estado heterárquico: o Movimento pela Base Nacional Comum Curricular no Brasil, 2018.

BARDIN, Laurence. Análise de conteúdo. Lisboa: Edições 70, 1977

BICHIR, R. Governança Multinível. Boletim de Análise Político - Institucional, nº19. Dezembro, 2018.

BORBA, Hérica. Dissertação de mestrado. Políticas Públicas Nacional para o ensino médio no Brasil (1996/2009): avanços e retrocessos na luta pelo direito à educação na era da cidadania. Universidade Católica de Minas Gerais. 2011.

Bresser Pereira, L. C. A reforma gerencial do Estado de 1995. RAP, Rio de Janeiro, 34(4):7-26, Jul./Ago. 2000. 
Bruns, Suelma \& Oliveira, Egléubia \& Oliveira, Maria \& Luiza, Vera. (2015). O modelo de ambiguidade-conflito como ferramenta de análise dos desafios da Assistência Farmacêutica em João Pessoa (PB). Saúde em Debate. 39. 64-75. 2015

Caderno CENPEC- Políticas para o ensino médio e desigualdades escolares e sociais / [organização CENPEC - Centro de Estudos e Pesquisas em Educação, Cultura e Ação Comunitária; coordenação Maria Alice Setubal e Antônio Augusto Gomes Batista]. — São Paulo: Fundação Santillana, 2017.

CARVALHO, José Mauricio Avilla. Educação em Disputa: Uma Análise sobre os Conflitos decorrentes da Reforma do Ensino Médio no Brasil sob o Prisma do Modelo de Coalizões de Defesa. 2019. 188 p. Dissertação (Mestrado em Administração). Instituto de Ciências Sociais Aplicadas, Programa de PósGraduação em Administração, Universidade Federal Rural do Rio de Janeiro, Seropédica, RJ, 2019.

CHIZZOTTI, A. Pesquisa em Ciências Humanas e Sociais. São Paulo: Cortez, 1998.

CONSED. Sobre o consed. Disponível em < http://www.consed.org.br/ consed/consed/missao-e-objetivos > acessado em 20 de maio de 2020.

CORTI, ANA PAULA. Política e significantes vazios: uma análise da reforma do ensino médio de 2017. Educ. rev., Belo Horizonte , v. 35, e201060, 2019.

CRESWEL, J. W. Projeto de pesquisa: método qualitativo, quantitativo e misto. 2. ed. Porto Alegre: Artmed, 2007.

DENZIN, N. K. e LINCOLN, Y. S. Introdução: a disciplina e a prática da pesquisa qualitativa. In: DENZIN, N. K. e LINCOLN, Y. S. (Orgs.). O planejamento da pesquisa qualitativa: teorias e abordagens. 2. ed. Porto Alegre: Artmed, 2006. p. 15-41.

DOMINGUES, José Juiz; TOSCHI, Nirza Seabra; OLIVEIRA, João Ferreira de. A reforma do Ensino Médio: a nova formulação curricular e a realidade da escola pública. Educ. Soc., Campinas, v. 21, n. 70, p. 63-79, Apr. 2000. 
FERNANDES, Reynaldo. Índice de Desenvolvimento da Educação Básica (Ideb). Brasília: Instituto Nacional de Estudos e Pesquisas Educacionais Anísio Teixeira, 2007.

FERRETI, Celso João; SILVA, Monica Ribeiro da. Reforma do ensino médio no contexto da medida provisória n o 746/2016: estado, currículo e disputas por hegemonia. Educ. Soc., Campinas, v. 38, n. 139, p. 385-404, jun. 2017.

FRIGOTTO, G. Concepções e mudanças no mundo do trabalho e o Ensino Médio. In: FRIGOTTO, G. et al. (Orgs.). Ensino médio integrado: concepções e contradições. São Paulo: Cortez, 2005. p. 57-82.

FRIGOTTO, Gaudêncio; CIAVATTA, Maria. Educação básica no Brasil na década de 1990: subordinação ativa e consentida à lógica do mercado. Educ. Soc., Campinas, v. 24, n. 82, p. 93-130, abr. 2003.

GIL, A. A. Métodos e técnicas de pesquisa social. 6. Ed. São Paulo: Atlas 2008.

GODOY, A. S. Refletindo sobre critérios de qualidade da pesquisa qualitativa. GESTÃO.Org - Revista Eletrônica de Gestão Organizacional, v. 3, n. 2, p. 80-89, 2005.

GOMES, Tânia Castro. A educação integral e o Programa Ensino Médio Inovador - ProEMI: singularidades desta política em uma escola estadual. / Tânia Castro Gomes. - Santarém, Pará, 2017.

HILL, Michael \& HUPE, Peter. The Multi-Layer Problem in Implementation Research. Public Management Review. 2003.

JESUS, Rosele Batista e FARENZENA, Nalú. Política curricular para a educação básica do Estado do Mato Grosso: um olhar sobre as orientações curriculares. IX ANPED SUL. 2012.

KUENZER, Acacia Zeneida. O Ensino Médio agora é para a vida: entre o pretendido, o dito e o feito. Educ. Soc., Campinas, v. 21, n. 70, p. 15-39, Apr. 2000.

KUNZ, Magali Seidel. Ensino Médio Politécnico: Prática Emancipatória para uma formação Integral?. Dissertação - (Mestrado em Educação) - Universidade Regional Integrada do Alto Uruguai e das Missões. 2015. 
LIMA, Marcelo; MACIEL, Samanta Lopes. A reforma do Ensino Médio do governo Temer: corrosão do direito à educação no contexto de crise do capital no Brasil. Rev. Bras. Educ., Rio de Janeiro, v. 23, e230058, 2018.

LINDBLOM, Charles E. "Still Muddling, Not Yet Through", Public Administation Review 39: 517-526. 1979

LOTTA, G. e BAUER, M. (Coord.). Pesquisa: mapeamento das iniciativas de desenvolvimento do ensino médio nos estados brasileiros. CONSED/Instituto Unibanco, novembro de 2018.

LOTTA, Gabriela \& BAUER Marcela \& ROJAS, Catherine \& JOBIM, Rita. Trajetórias de implementação de mudanças no ensino médio nos estados brasileiros: impactos da Lei 13.415/2017. Artigo 3 IU Enapg. 2019ª .

LOTTA, Gabriela \& BAUER Marcela \& ROJAS, Catherine \& JOBIM, Rita. Efeito de mudanças no contexto de implementação de uma política multinível: análise do caso da reforma do Ensino Médio no Brasil. 2020 (no prelo)

LUDKE, M; ANDRÉ, M. Pesquisa em educação: abordagens qualitativas. São Paulo: EPU, 1986.

LUNA, Sergio Vasconcelos de. Planejamento de pesquisa: uma introdução/ Sergio Vasconcelos de Luna. - 2 ed. São Paulo: EDUC, 2013.

MACIEL, Caroline Stéphanie Francis dos Santos. Uma Avaliação da Lei $\mathbf{n}^{\mathbf{0}}$ 13.415/17 a partir da Legística e das Metas do PNE. Educ. Real., Porto Alegre, v. 44, n. 3, e84925, 2019.

MARCONI, M; LAKATOS, E. Técnicas de pesquisa. São Paulo: Atlas, 1982.

MATLAND, R. Synthesizing the implementation literature: the ambiguityconflict model of policy implementation. JPART, v. 5, n. 2, p. 145-174. 1995.

MELO, Savana \& DUARTE, Adriana. Políticas para o ensino médio no Brasil: Perspectivas para a universalização. Cad. Cedes, Campinas, vol. 31, n. 84, p. 231-251, maio-ago. 2011

MENEZES, Ebenezer Takuno de; SANTOS, Thais Helena dos. Verbete PROMED (Programa de Melhoria e Expansão do Ensino Médio). Dicionário 
Interativo da Educação Brasileira - Educabrasil. São Paulo: Midiamix, 2001. Disponível em: <https://www.educabrasil. com.br/promed-programa-de-melhoriae-expansao-do-ensino-medio/>. Acesso em: 07 de maio de 2020.

MENEZES, Janaína Specht da Silva; SOUZA, Donaldo Bello de. Monitoramento e avaliação nos Planos Estaduais de Educação consoantes ao novo PNE. ProPosições, Campinas, v. 29, n. 3, p. 614-639, set. 2018.

MESQUITA, Silvana Soares de Araujo; LELIS, Isabel Alice Oswaldo Monteiro. Cenários do Ensino Médio no Brasil. Ensaio: aval.pol.públ.Educ., Rio de Janeiro, v. 23, n. 89, p. 821-842, Dec. 2015.

MINAYO, M.C.S. Pesquisa social: teoria, método e criatividade. 22. Ed. Petrópolis, RJ: Vozes, 2003.

Movimento Nacional em Defesa do Ensino Médio. Disponível em: http://www.observatoriodoensinomedio.ufpr.br/movimento-nacional-em-defesado-ensino-medio-2/. Acessado em 30 de novembro de 2018.

NOBILE, Michelle Graziela de Oliveira. Dissertação de Mestrado. A política de formação continuada dos professores do ensino médio de uma escola estadual do município de Diamantino/MT. Programa de Pós-Graduação em educação. Universidade Federal de Mato Grosso - UFMT. Cuiabá, 2014.

Observatório do PNE. 2018 disponível em: http://www.observatoriodopne.org.br/ metas-pne/ 3-ensino-medio acessado em 04 de novembro de 2018.

OLIVEIRA, Ivanilde Apoluceno de; FONSECA, Maria de Jesus da Conceição Ferreira; SANTOS, Tânia Regina Lobato dos. A entrevista na pesquisa educacional. Metodologias e técnicas de pesquisa em educação/ organizadoras: Maria Inês Marcondes, Elizabeth Teixeira, Ivanilde Apoluceno de Oliveira. Belém: EDUEPA, 2010.

OLIVEIRA, Ramon de. Possibilidades do Ensino Médio Integrado diante do financiamento público da educação. Educ. Pesqui., São Paulo, v. 35, n. 1, p. 5166, abr. 2009. 
OLIVEIRA, Romualdo Portela de. Da universalização do ensino fundamental ao desafio da qualidade: uma análise histórica. Educ. Soc., Campinas, v. 28, n. 100, p. 661-690, Oct. 2007.

PEREIRA, Breno Diniz A.; LOBLER, Mauri Leoldi \& SIMONETTO, Eugênio de Oliveira. Análise dos modelos de tomada de decisão sob o enfoque cognitivo. Revista Adm. UFSM, Santa Maria, v. 3,n. 2, p. 260-268, mai./ago. 2010.

PERONI, V. et al. Relações entre o público e o privado na educação básica brasileira: implicações para processos de democratização. Políticas Educativas, Porto Alegre, v. 7, n.1, p. 92-109, 2013.

MINAYO, Maria Cecília de Souza (organizadora).Pesquisa Social: teoria, método e criatividade/ Sueli Ferreira Deslandes, Romeu Gomes; 28. ed.Petrópolis, RJ: Vozes, 2009.

RICCI, Paolo; TOMIO, Fabricio. O poder da caneta: a Medida Provisória no processo legislativo estadual. Opin. Publica, Campinas, v. 18, n. 2, p. 255-277, nov. 2012.

SANTOS, Jean Mac Cole Tavares; DIÓGENES, Elione Maria Nogueira. Políticas públicas de educação para o ensino médio no final do século XX: história em contexto. Revista on line de Política e Gestão Educacional, [S.1.], n. 14, feb. 2017. SCHWARTZMAN, Simon. O novo ensino médio: o difícil caminho à frente. In Ensino Médio: impasses e dilemas / Candido Alberto Gomes, Ivar César Oliveira de Vasconcelos, Silvia Regina dos Santos Coelho (Orgs.) / Brasília: Cidade Gráfica Editora, 2018.

SILVA, Andréa Giordanna Araujo da. Ensino (em tempo) Integral: Proposta oficiais versus dialética do real. Tese (doutorado em Educação) - Universidade Federal de Pernambuco. Pernambuco. 2016.

SILVA, Antônio Torquarto. Desafios do ensino médio no projeto político pedagógico na perspectiva de educação integral. Dissertação - (Mestrado em Educação) - Pontifícia Universidade Católica de São Paulo. 2017. 
SOUZA, Antonio Ricardo de e SOUZA, Janice Kanissek de. Gestão da educação pública em Mato Grosso: Análise a partir de alguns indicadores de desempenho. UNICiências, v.7. 2003.

SOUZA, Celina. Políticas públicas, uma revisão de literatura. Sociologias, Porto Alegre, ano 8, n 16, jul/dez 2006, p. 20-45

SOUZA, Donaldo Bello de; MENEZES, Janaína Specht da Silva. Elaboração e aprovação de planos de educação no Brasil: do nacional ao local. Ensaio: aval. pol. públ. Educ., Rio de Janeiro, v. 23, n. 89, p. 901-936, Dec. 2015.

SZYMANSKI, H. (org). A entrevista na pesquisa em educação: a prática reflexiva. Brasília: Líber Livro, 2004.

Todos pela Educação. Anuário Brasileiro da Educação Básica. Editora Moderna. 2018.

VIEIRA, M. M. F. e ZOUAIN, D. M. Pesquisa qualitativa em administração: teoria e prática. Rio de Janeiro: Editora FGV, 2005.

YIN, Robert K. Estudo de Caso: Planejamento e Métodos. Bookman Editora, 2015.

ZIBAS, Dagmar M. L.. A reforma do ensino médio nos anos de 1990: o parto da montanha e as novas perspectivas. Rev. Bras. Educ., Rio de Janeiro, n. 28, p. 24-36, Apr. 2005

ZIBAS, Dagmar M. L.. Refundar o ensino médio? Alguns antecedentes e atuais desdobramentos das políticas dos anos de 1990. Educ. Soc., Campinas, v. 26, n. 92, p. 1067-1086, Oct. 2005. 
Anexos

Anexo 1 - Roteiro das entrevistas

PONTIFÍCIA UNIVERSIDADE CATÓLICA DO RIO DE JANEIRO

Programa de Pós-Graduação em Educação

$\mathrm{PUC}_{\mathrm{R}}$

Roteiro de Entrevista Semiestruturada

Nome

do

entrevistado:

Cargo:

Local

da

entrevista:

Pesquisadora:

Data da entrevista:

Este roteiro foi elaborado a partir da leitura e análise de documentos e materiais de referência do Novo Ensino Médio, dentre eles:

- o Portal do Novo Ensino Médio;

- o Guia de Implementação do Novo Ensino Médio;

- a Portaria 649/2018 que institui o Programa de Apoio ao Novo Ensino Médio, o Documento Orientador que a subsidia;

- a Portaria 1.024/2018 que institui Programa Dinheiro Direto na Escola às unidades escolares pertencentes às Secretarias participantes do Programa de Apoio ao Novo Ensino Médio;

- a Resolução MEC nº 21/ 2018 que destina recursos financeiros, nos moldes operacionais e regulamentares do Programa Dinheiro Direto na Escola;

- Programa de Apoio à Implementação da Base Nacional Comum Curricular - ProBNCC; 
- Portaria 1.023/2018 que estabelece diretrizes, parâmetros e critérios para a realização de avaliação de impacto do Programa de Fomento às Escolas de Ensino Médio em Tempo Integral - EMTI e seleção de novas unidades escolares para o Programa;

\section{Rapport - Aquecimento e percepções iniciais sobre o tema}

A entrevista abordará as mudanças no Ensino Médio e sobre a implementação do Novo Ensino Médio.

1) Quais são as expectativas em relação ao NEM?

a) o que ele está trazendo de novo para a SEE?

b) o que ele está trazendo de bom?

c) que pontos desse movimento têm se mostrado mais desafiadores para a SEE?

2) Como você avalia a implementação do NEM no estado? É um movimento novo? Já vinha acontecendo? Desde quando?

\section{Informações sobre a rede - Histórico antes da Reforma}

Para entender sobre o processo de implementação do NEM, é importante entender o contexto da secretaria.

3) Quais são as ações de Educação Integral existentes na rede?

4) Como estava estruturado o currículo para o Ensino Médio?

\section{Prioridades e planejamento}

5) Como a Reforma do Ensino Médio chegou à Secretaria Estadual de Educação (meio de comunicação, pessoas e instituições relacionadas)?

6) O que muda com a chegada da Reforma do Ensino Médio?

7) No que vocês estão trabalhando mais atualmente?

8) Checar (ver em que passo de implementação está cada um dos itens abaixo ou se há planos para sua implementação futura)

- elaboração do novo currículo (que contempla a BNCC)

- desenho de itinerários

- 5o itinerário

- desenho de flexibilização curricular

- ampliação de carga horária

- desenvolvimento de práticas de protagonismo do estudante.

9) Existe alguma mudança que já está sendo implementada esse ano? Ou seja, existem iniciativas que já têm as características do NEM que já estão em teste/piloto/experimentação?

a) Pode contar um pouco a respeito? 
b) Sobre as escolas piloto: como foram escolhidas? Segundo que critérios? E desde quando elas começaram a ser colocadas em prática?

c) Qual é a escala do que está sendo implementado atualmente? (porcentagem ou número aproximado de escolas na rede, ou se for formação, que público atinge e qual o seu tamanho da rede, se for desenvolvimento de sistemas, novos procedimentos, tentar entender a dimensão no contexto da rede)

10) O que orienta o movimento de mudança? No que a SEE se baseia ou se inspira para planejar e/ou implementar o NEM?

Fazer check list:

- Guia de implementação do NEM?

- Programa de apoio ao NEM (Portaria 649/2018)?

- As atividades do Consed?

- A política de Educação do Estado?

\section{Relações de governança interna}

As mudanças que o NEM traz para as Secretarias Estaduais de Educação parecem ser grandes e significativas. Nesse sentido, a proposta é entender como a Secretaria está se organizando internamente.

11) Como está sendo a organização interna da Secretaria para lidar com as mudanças?

Checar:

- foi montado o comitê de acompanhamento da implementação do NEM?

- Houve ou haverá:

○ reestruturação organizacional

- ampliação e fortalecimento de equipe gestora da sede

- ampliação ou reestruturação da equipe gestora das assessorias pedagógicas e das unidades de ensino (escolas)

- ampliação ou reestruturação da equipe de professores

- mudanças em processos (rotinas administrativas)

12) Estão recebendo a consultoria/apoio o técnico previsto nas normativas?

13) E o apoio financeiro? Do governo federal? Ou de quem?

14) E estão implementando ou planejando a implementação da plataforma digital que apoia o diagnóstico e implementação (documento orientador do plano de apoio ao NEM)?

15) Como está o diagnóstico das capacidades atuais da rede? Está sendo realizado? Por quem?

16) Como você avalia a capacidade de gestão para atuar nesse processo de mudança? 
Checar:

- Estão fazendo ou já fizeram a matriz de implementação?

- Qual a estrutura para implementação? Passos da implementação

\section{Implementação da REM}

17) Quando o NEM entrará em vigor nas escolas? (Considerar a resposta do item 9)

18) Se for piloto, quantas escolas? (verificar porcentagem)

19) Se for piloto, quais escolas? Quais foram os critérios de seleção e qual a previsão para ampliação para as demais escolas? (Verificar sobre o cronograma para a implementação e sobre o Proposta de Flexibilização Curricular -PFC - por escola)

20) Qual serão os itinerários oferecidos pela rede? Quais critérios para a seleção?

São diversos os públicos impactados com as mudanças trazidas pelo NEM na rede. Os estudantes, os professores, os gestores das UE.

21) Estão promovendo atividades de divulgação e mobilização, como audiências, seminários, reuniões etc?

22) Com quais atores específicos e separados (professores, alunos etc)

23) A formação continuada está na pauta?
a) Como ela está sendo pensada?
b) Alguma iniciativa já aconteceu ou está acontecendo?
c) É ofertada internamente?
d) É ofertada também por parceiros (3o setor, MEC)?
e) Em qual modalidade acontece? (presencial, ead)
f) Atinge quais atores da rede (professores, gestores. técnicos da sede)

Mudanças na rede muitas vezes vêm acompanhadas pela criação de novos normativos (instrução normativa, edital, portaria, lei).

24) Que normativas estão sendo criadas (em processo de criação) nesse processo?

(Se ainda não foram criadas, há um planejamento para criação?)

Checar normativas sobre:

- $\quad$ sistema de matrícula

- sistema de certificação

- sistema de gestão escolar

- edital de contratação de professor e demais profissionais da educação,

- notório saber

- estabelecimento de parcerias 
Uma mudança desse tamanho traz junto a necessidade da SEE interagir com diversos atores/órgão/instituições.

25) Com quais outras organizações a SEE precisa se articular para poder implementar as mudanças?

Checar:

- Como está a relação da Secretaria com o MEC?

- E como estão os programas do governo federal?

26) O que está vigorando, ou quais desses programas serve como incentivo às ações da SEE:

- Programa de apoio ao novo EM

- ProBNCC

- PDDE

- Programa de Fomento à Implementação de Escolas de Tempo Integral (EMTI)

- Programa de Avaliação das Escolas de Tempo Integral (EMTI)

27) Há algum parceiro do 3o setor dando apoio a esse movimento?

28) Qual/Quais?

29) Qual o papel/atividade que esses parceiros estão desenvolvendo?

30) Como é a relação com ele/eles?

31) Qual o papel do Consed nesse movimento? Qual é/como está a relação da SEE com o Consed?

32) Como está a relação da SEE com o Conselho Estadual de Educação?

33) E qual é o papel da SEE em relação às Secretarias Municipais de Educação? Checar: articulação com os anos finais do Fundamental

-Tem algo mais que você gostaria de compartilhar para enriquecer a conversa? 
Anexo 2 - Relação de escolas indígenas estaduais

\begin{tabular}{|c|c|c|c|c|}
\hline Escola & $\begin{array}{l}\text { Código } \\
\text { INEP }\end{array}$ & Município & Porte da Escola & $\begin{array}{l}\text { Etapas e Modalidade } \\
\text { de Ensino Oferecidas }\end{array}$ \\
\hline EEI PE DE MUTUM & 51011417 & Juara & $\begin{array}{l}\text { Entre } 51 \text { e } 200 \text { matrículas de } \\
\text { escolarização }\end{array}$ & $\begin{array}{l}\text { Ensino Fundamental, Ensino } \\
\text { Médio }\end{array}$ \\
\hline $\begin{array}{ll}\text { EE } & \text { INDIGENA } \\
\text { TAPIRAPE } & \end{array}$ & 51020378 & $\begin{array}{l}\text { Santa } \\
\text { Terezinha }\end{array}$ & $\begin{array}{l}\text { Entre } 51 \text { e } 200 \text { matrículas de } \\
\text { escolarização }\end{array}$ & $\begin{array}{lll}\text { Ensino } & \text { Fundamental, } & \text { Ensino } \\
\text { Médio, Educação de } & \text { Jovens } \\
\text { Adultos } & & \\
\end{array}$ \\
\hline $\begin{array}{ll}\text { EE } & \text { INDIGENA } \\
\text { OMORA }\end{array}$ & 51022214 & Campinápolis & $\begin{array}{l}\text { Entre } 51 \text { e } 200 \text { matrículas de } \\
\text { escolarização }\end{array}$ & $\begin{array}{lll}\text { Ensino Fundamental, } & \text { Ensino } \\
\text { Médio, Educação de } & \text { Jovens } \\
\text { Adultos } & & \\
\end{array}$ \\
\hline $\begin{array}{l}\text { EE INDIGENA DE } \\
\text { EDUCACAO BASICA } \\
\text { BUTSE WAWE } \\
\end{array}$ & 51022249 & Campinápolis & $\begin{array}{l}\text { Entre } 201 \text { e } 500 \text { matrículas de } \\
\text { escolarização }\end{array}$ & $\begin{array}{lll}\text { Ensino } & \text { Fundamental, } & \text { Ensino } \\
\text { Médio, Educação de } & \text { Jovens } \\
\text { Adultos } & & \\
\end{array}$ \\
\hline $\begin{array}{ll}\text { EE } & \text { INDIGENA } \\
\text { EDUCACAO } & \text { BASICA } \\
\text { XAVANTE } & \end{array}$ & 51022273 & Campinápolis & $\begin{array}{l}\text { Entre } 51 \text { e } 200 \text { matrículas de } \\
\text { escolarização }\end{array}$ & $\begin{array}{l}\text { Ensino Fundamental, Ensino } \\
\text { Médio, Educação de } \\
\text { Adultos }\end{array}$ \\
\hline $\begin{array}{l}\text { EE } \text { INDIGENA DOM } \\
\text { FELIPPO RINALDI }\end{array}$ & 51024640 & $\begin{array}{l}\text { Barra do } \\
\text { Garças } \\
\end{array}$ & $\begin{array}{l}\text { Entre } 201 \text { e } 500 \text { matrículas de } \\
\text { escolarização }\end{array}$ & $\begin{array}{l}\text { Ensino Fundamental, Ensino } \\
\text { Médio }\end{array}$ \\
\hline $\begin{array}{l}\text { EE } \quad \text { INDIGENA } \\
\text { KOROGEDO PARU }\end{array}$ & 51041626 & $\begin{array}{l}\text { Santo Antônio } \\
\text { do Leverger }\end{array}$ & $\begin{array}{l}\text { Entre } 51 \text { e } 200 \text { matrículas de } \\
\text { escolarização }\end{array}$ & $\begin{array}{lll}\text { Ensino Fundamental, Ensino } \\
\text { Médio, Educação de } & \text { Jovens } \\
\text { Adultos } & & \\
\end{array}$ \\
\hline $\begin{array}{ll}\text { EE } & \text { INDIGENA } \\
\text { PIEBAGA } & \\
\end{array}$ & 51041723 & $\begin{array}{l}\text { Santo Antônio } \\
\text { do Leverger }\end{array}$ & $\begin{array}{lcc}\text { Até } & 50 \quad \text { matrículas } & \text { de } \\
\text { escolarização }\end{array}$ & $\begin{array}{l}\text { Ensino Fundamental, Educação } \\
\text { de Jovens Adultos }\end{array}$ \\
\hline $\begin{array}{ll}\text { EE } & \text { INDIGENA } \\
\text { SAGRADO } & \text { CORACAO } \\
\text { DE JESUS } & \\
\end{array}$ & 51047349 & $\begin{array}{l}\text { General } \\
\text { Carneiro }\end{array}$ & $\begin{array}{l}\text { Entre } 51 \text { e } 200 \text { matrículas de } \\
\text { escolarização }\end{array}$ & $\begin{array}{l}\text { Ensino Fundamental, Ensino } \\
\text { Médio }\end{array}$ \\
\hline $\begin{array}{lll}\text { EE } & \text { INDIGENA } & \text { SAO } \\
\text { JOSE } & \text { SANGRADOURO }\end{array}$ & 51047357 & $\begin{array}{l}\text { General } \\
\text { Carneiro }\end{array}$ & $\begin{array}{l}\text { Entre } 201 \text { e } 500 \text { matrículas de } \\
\text { escolarização }\end{array}$ & $\begin{array}{lll}\text { Ensino } & \text { Fundamental, Ensino } \\
\text { Médio } & & \\
\end{array}$ \\
\hline $\begin{array}{ll}\text { EE } & \text { FRANKLIN } \\
\text { CASSIANO } & \end{array}$ & 51048728 & Poxoréu & $\begin{array}{l}\text { Entre } 201 \text { e } 500 \text { matrículas de } \\
\text { escolarização }\end{array}$ & $\begin{array}{lll}\text { Ensino Fundamental, } & \text { Ensino } \\
\text { Médio, Educação de } & \text { Jovens } \\
\text { Adultos } & & \end{array}$ \\
\hline $\begin{array}{ll}\text { EE } & \text { INDIGENA } \\
\text { ESTRELA } & \end{array}$ & 51054990 & Campinápolis & $\begin{array}{l}\text { Entre } 201 \text { e } 500 \text { matrículas de } \\
\text { escolarização }\end{array}$ & $\begin{array}{lll}\text { Ensino Fundamental, Ensino } \\
\text { Médio, Educação de } & \text { Jovens } \\
\text { Adultos } & & \\
\end{array}$ \\
\hline $\begin{array}{lr}\text { EE } & \text { INDIGENA } \\
\text { CENTRAL ESTADUAL } \\
\text { DIAUARUN }\end{array}$ & 51059274 & $\begin{array}{l}\text { São Félix do } \\
\text { Araguaia }\end{array}$ & $\begin{array}{l}\text { Entre } 201 \text { e } 500 \text { matrículas de } \\
\text { escolarização }\end{array}$ & Ensino Fundamental \\
\hline $\begin{array}{lr}\text { EE } & \text { INDIGENA } \\
\text { CENTRAL } & \text { ESTADUAL } \\
\text { KARIB } & \\
\end{array}$ & 51059479 & $\begin{array}{l}\text { Gaúcha do } \\
\text { Norte }\end{array}$ & $\begin{array}{l}\text { Entre } 201 \text { e } 500 \text { matrículas de } \\
\text { escolarização }\end{array}$ & $\begin{array}{lll}\text { Ensino } & \text { Fundamental, } & \text { Ensino } \\
\text { Médio, Educação de } & \text { Jovens } \\
\text { Adultos } & & \\
\end{array}$ \\
\hline $\begin{array}{l}\text { EE } \\
\text { MAVUTSININ }\end{array}$ & 51059487 & $\begin{array}{l}\text { Gaúcha do } \\
\text { Norte }\end{array}$ & $\begin{array}{l}\text { Entre } 51 \text { e } 200 \text { matrículas de } \\
\text { escolarização }\end{array}$ & Ensino Fundamental \\
\hline $\begin{array}{lr}\text { EE } & \text { INDIGENA } \\
\text { CENTRAL } & \text { ESTADUAL } \\
\text { IKPENG } & \\
\end{array}$ & 51059576 & Feliz Natal & $\begin{array}{l}\text { Entre } 201 \text { e } 500 \text { matrículas de } \\
\text { escolarização }\end{array}$ & $\begin{array}{lll}\text { Ensino } & \text { Fundamental, Ensino } \\
\text { Médio } & \end{array}$ \\
\hline $\begin{array}{l}\text { EE INDIGENA DE } \\
\text { EDUCACAO BASICA } \\
\text { ETENHIRITIPA } \\
\end{array}$ & 51060116 & Canarana & $\begin{array}{l}\text { Até } 50 \text { matrículas } \mathrm{de} \\
\text { escolarização }\end{array}$ & Ensino Fundamental \\
\hline $\begin{array}{l}\text { EE } \\
\text { EDDIGENA DE } \\
\text { EDUCACAO } \\
\text { JUPORIJUP }\end{array}$ & 51060833 & Juara & $\begin{array}{l}\text { Entre } 51 \text { e } 200 \text { matrículas de } \\
\text { escolarização }\end{array}$ & $\begin{array}{lll}\text { Ensino } & \text { Fundamental, Ensino } \\
\text { Médio } & & \end{array}$ \\
\hline $\begin{array}{l}\text { EE INDIGENA EDUC } \\
\text { BASICA LEONARDO } \\
\text { CRIXI APIAKA } \\
\end{array}$ & 51060841 & Juara & $\begin{array}{l}\text { Entre } 51 \text { e } 200 \text { matrículas de } \\
\text { escolarização }\end{array}$ & $\begin{array}{lll}\text { Ensino } & \text { Fundamental, Ensino } \\
\text { Médio } & \end{array}$ \\
\hline $\begin{array}{lr}\text { EE } & \text { INDIGENA } \\
\text { MARIMBU } & \\
\end{array}$ & 51061104 & Poxoréu & $\begin{array}{l}\text { Entre } 51 \text { e } 200 \text { matrículas de } \\
\text { escolarização }\end{array}$ & Ensino Fundamental \\
\hline $\begin{array}{l}\text { EE INDIGENA TAPURA } \\
\text { IRANTXE }\end{array}$ & 51064383 & Brasnorte & $\begin{array}{l}\text { Entre } 51 \text { e } 200 \text { matrículas de } \\
\text { escolarização }\end{array}$ & $\begin{array}{l}\text { Ensino Fundamental, Ensino } \\
\text { Médio }\end{array}$ \\
\hline $\begin{array}{lr}\text { EE } & \text { INDIGENA } \\
\text { JUCELINO TSEREMAA }\end{array}$ & 51064391 & $\begin{array}{l}\text { Barra do } \\
\text { Garças }\end{array}$ & $\begin{array}{l}\text { Entre } 51 \text { e } 200 \text { matrículas de } \\
\text { escolarização }\end{array}$ & $\begin{array}{lll}\text { Ensino } & \text { Fundamental, Ensino } \\
\text { Médio } & & \\
\end{array}$ \\
\hline
\end{tabular}




\begin{tabular}{|c|c|c|c|c|}
\hline $\begin{array}{ll}\text { EE INDIGENA } & \text { RAI } \\
\text { RATE } & \end{array}$ & 51064405 & Campinápolis & $\begin{array}{l}\text { Entre } 201 \text { e } 500 \text { matrículas de } \\
\text { escolarização }\end{array}$ & $\begin{array}{lll}\text { Ensino Fundamental, } & \text { Ensino } \\
\text { Médio, Educação de } & \text { Jovens } \\
\text { Adultos } & & \\
\end{array}$ \\
\hline $\begin{array}{lr}\text { EE } & \text { INDIGENA } \\
\text { SAMUEL SAHUTUWE }\end{array}$ & 51064448 & Canarana & $\begin{array}{l}\text { Entre } 201 \text { e } 500 \text { matrículas de } \\
\text { escolarização }\end{array}$ & $\begin{array}{lll}\text { Ensino } & \text { Fundamental, } & \text { Ensino } \\
\text { Médio, Educação de } & \text { Jovens } \\
\text { Adultos } & & \\
\end{array}$ \\
\hline $\begin{array}{ll}\text { EEI PIRINEUS } & \text { DE } \\
\text { SOUZA } & \\
\end{array}$ & 51064502 & Comodoro & $\begin{array}{l}\text { Entre } 51 \text { e } 200 \text { matrículas de } \\
\text { escolarização }\end{array}$ & $\begin{array}{lll}\text { Ensino } & \text { Fundamental, Ensino } \\
\text { Médio } & & \\
\end{array}$ \\
\hline $\begin{array}{ll}\text { EE } & \text { INDIGENA } \\
\text { GORONA } & \\
\end{array}$ & 51064553 & $\begin{array}{l}\text { Peixoto de } \\
\text { Azevedo }\end{array}$ & $\begin{array}{l}\text { Entre } 51 \text { e } 200 \text { matrículas de } \\
\text { escolarização }\end{array}$ & $\begin{array}{l}\text { Ensino Fundamental, Ensino } \\
\text { Médio }\end{array}$ \\
\hline $\begin{array}{l}\text { EE INDIGENA } \\
\text { BITAHAMA }\end{array}$ & 51064847 & $\begin{array}{l}\text { São José do } \\
\text { Xingu }\end{array}$ & $\begin{array}{l}\text { Entre } 51 \text { e } 200 \text { matrículas de } \\
\text { escolarização }\end{array}$ & $\begin{array}{lll}\text { Ensino } & \text { Fundamental, } & \text { Ensino } \\
\text { Médio, Educação de } & \text { Jovens } \\
\text { Adultos } & & \\
\end{array}$ \\
\hline $\begin{array}{lr}\text { ESCOLA } & \text { ESTADUAL } \\
\text { INDIGENA } & \text { DAVID } \\
\text { AIRERO } & \\
\end{array}$ & 51065380 & Campinápolis & $\begin{array}{l}\text { Entre } 201 \text { e } 500 \text { matrículas de } \\
\text { escolarização }\end{array}$ & $\begin{array}{lll}\text { Ensino } & \text { Fundamental, } & \text { Ensino } \\
\text { Médio, Educação de } & \text { Jovens } \\
\text { Adultos } & & \\
\end{array}$ \\
\hline $\begin{array}{l}\text { EE } \quad \text { INDIGENA } \\
\text { CENTRAL AIHA }\end{array}$ & 51067811 & $\begin{array}{l}\text { Gaúcha do } \\
\text { Norte }\end{array}$ & $\begin{array}{l}\text { Entre } 201 \text { e } 500 \text { matrículas de } \\
\text { escolarização }\end{array}$ & $\begin{array}{lll}\text { Ensino } & \text { Fundamental, } & \text { Ensino } \\
\text { Médio, Educação de } & \text { Jovens } \\
\text { Adultos } & & \\
\end{array}$ \\
\hline $\begin{array}{l}\text { EE INDIGENA ZAWA } \\
\text { KAREJ PANGYJEJ }\end{array}$ & 51067854 & Rondolândia & $\begin{array}{l}\text { Entre } 51 \text { e } 200 \text { matrículas de } \\
\text { escolarização }\end{array}$ & $\begin{array}{lll}\text { Ensino Fundamental, Ensino } \\
\text { Médio }\end{array}$ \\
\hline $\begin{array}{l}\text { ESCOLA ESTADUAL } \\
\text { INDIGENA } \\
\text { CONSTANTINO } \\
\text { TSEREROWE } \\
\end{array}$ & 51068605 & Campinápolis & $\begin{array}{l}\text { Entre } 51 \text { e } 200 \text { matrículas de } \\
\text { escolarização }\end{array}$ & $\begin{array}{lll}\text { Ensino } & \text { Fundamental, } & \text { Ensino } \\
\text { Médio, Educação de } & \text { Jovens } \\
\text { Adultos } & & \\
\end{array}$ \\
\hline $\begin{array}{l}\text { EE INDIGENA } \\
\text { CENTRAL LEONARDO } \\
\text { VILLAS BOAS } \\
\end{array}$ & 51089343 & $\begin{array}{l}\text { Gaúcha do } \\
\text { Norte }\end{array}$ & $\begin{array}{l}\text { Entre } 201 \text { e } 500 \text { matrículas de } \\
\text { escolarização }\end{array}$ & $\begin{array}{lll}\text { Ensino } & \text { Fundamental, } & \text { Ensino } \\
\text { Médio, Educação de } & \text { Jovens } \\
\text { Adultos } & & \\
\end{array}$ \\
\hline $\begin{array}{l}\text { EE INDIGENA MARIO } \\
\text { JURUNA }\end{array}$ & 51090554 & $\begin{array}{l}\text { Barra do } \\
\text { Garças }\end{array}$ & $\begin{array}{l}\text { Entre } 51 \text { e } 200 \text { matrículas de } \\
\text { escolarização }\end{array}$ & $\begin{array}{lll}\text { Ensino Fundamental, Ensino } \\
\text { Médio }\end{array}$ \\
\hline $\begin{array}{ll}\text { EE } & \text { INDIGENA } \\
\text { ESTADUAL HADORI }\end{array}$ & 51090600 & Luciara & $\begin{array}{l}\text { Entre } 51 \text { e } 200 \text { matrículas de } \\
\text { escolarização }\end{array}$ & $\begin{array}{lll}\text { Ensino } & \text { Fundamental, } & \text { Ensino } \\
\text { Médio, Educação de } & \text { Jovens } \\
\text { Adultos } & & \\
\end{array}$ \\
\hline EE INDIGENA ITXALA & 51090619 & $\begin{array}{l}\text { Santa } \\
\text { Terezinha }\end{array}$ & $\begin{array}{l}\text { Entre } 51 \text { e } 200 \text { matrículas de } \\
\text { escolarização }\end{array}$ & $\begin{array}{lll}\text { Ensino } & \text { Fundamental, } & \text { Ensino } \\
\text { Médio, Educação de } & \text { Jovens } \\
\text { Adultos } & & \\
\end{array}$ \\
\hline EEI ETEREPUIY & 51091178 & Juína & $\begin{array}{l}\text { Entre } 51 \text { e } 200 \text { matrículas de } \\
\text { escolarização }\end{array}$ & Ensino Fundamental \\
\hline $\begin{array}{ll}\text { EE ADECA } & \text { VELA } \\
\text { ARARA } & \\
\end{array}$ & 51091240 & Aripuanã & $\begin{array}{l}\text { Até } 50 \text { matrículas } \mathrm{de} \\
\text { escolarização }\end{array}$ & Ensino Fundamental \\
\hline $\begin{array}{l}\text { EE INDIGENA } \\
\text { PASAPKAREEJ }\end{array}$ & 51091259 & Aripuanã & $\begin{array}{l}\text { Entre } 51 \text { e } 200 \text { matrículas de } \\
\text { escolarização }\end{array}$ & Ensino Fundamental \\
\hline $\begin{array}{l}\text { EE INDIGENA ADAO } \\
\text { TOPTIVO }\end{array}$ & 51091267 & $\begin{array}{l}\text { General } \\
\text { Carneiro }\end{array}$ & $\begin{array}{l}\text { Entre } 51 \text { e } 200 \text { matrículas de } \\
\text { escolarização }\end{array}$ & $\begin{array}{lll}\text { Ensino } & \text { Fundamental, } & \text { Ensino } \\
\text { Médio, Educação de } & \text { Jovens } \\
\text { Adultos } & & \\
\end{array}$ \\
\hline $\begin{array}{lll}\text { EE } & \text { INDIGENA } & \text { KOGE } \\
\text { EIARI } & \\
\end{array}$ & 51091275 & $\begin{array}{l}\text { Barão de } \\
\text { Melgaço }\end{array}$ & $\begin{array}{l}\text { Até } 50 \text { matrículas de } \\
\text { escolarização }\end{array}$ & $\begin{array}{lll}\text { Ensino } & \text { Fundamental, Ensino } \\
\text { Médio } & & \\
\end{array}$ \\
\hline $\begin{array}{l}\text { EE INDIGENA } \\
\text { ITAWA }\end{array}$ & 51091291 & Confresa & $\begin{array}{l}\text { Entre } 201 \text { e } 500 \text { matrículas de } \\
\text { escolarização }\end{array}$ & $\begin{array}{lll}\text { Ensino } & \text { Fundamental, } & \text { Ensino } \\
\text { Médio, Educação de } & \text { Jovens } \\
\text { Adultos } & & \\
\end{array}$ \\
\hline $\begin{array}{l}\text { EE INDIGENA XINUI } \\
\text { MYKY }\end{array}$ & 51091500 & Brasnorte & $\begin{array}{l}\text { Até } 50 \text { matrículas de } \\
\text { escolarização }\end{array}$ & $\begin{array}{lll}\text { Ensino } & \text { Fundamental, Ensino } \\
\text { Médio } & & \\
\end{array}$ \\
\hline $\begin{array}{lrl}\text { EE } & \text { INDIGENA } & \text { ELIO } \\
\text { TURI RONDON } & \end{array}$ & 51092727 & $\begin{array}{l}\text { Peixoto de } \\
\text { Azevedo }\end{array}$ & $\begin{array}{l}\text { Entre } 51 \text { e } 200 \text { matrículas de } \\
\text { escolarização }\end{array}$ & $\begin{array}{lll}\text { Ensino } & \text { Fundamental, Ensino } \\
\text { Médio, Educação de } & \text { Jovens } \\
\text { Adultos } & & \\
\end{array}$ \\
\hline $\begin{array}{l}\text { EE INDIGENA RAIWI A } \\
\text { XAVANTE }\end{array}$ & 51093600 & $\begin{array}{l}\text { General } \\
\text { Carneiro } \\
\end{array}$ & $\begin{array}{l}\text { Até } 50 \text { matrículas de } \\
\text { escolarização }\end{array}$ & $\begin{array}{lll}\text { Ensino } & \text { Fundamental, Ensino } \\
\text { Médio } & & \\
\end{array}$ \\
\hline $\begin{array}{l}\text { EE INDIGENA ULISSES } \\
\text { GUIMARAES }\end{array}$ & 51093626 & $\begin{array}{l}\text { Barra do } \\
\text { Garças }\end{array}$ & $\begin{array}{l}\text { Entre } 51 \text { e } 200 \text { matrículas de } \\
\text { escolarização }\end{array}$ & $\begin{array}{lll}\text { Ensino } & \text { Fundamental, Ensino } \\
\text { Médio } & & \\
\end{array}$ \\
\hline $\begin{array}{l}\text { EE INDIGENA } \\
\text { CHIQUITANOS }\end{array}$ & 51093642 & $\begin{array}{l}\text { Porto } \\
\text { Esperidião }\end{array}$ & $\begin{array}{l}\text { Entre } 51 \text { e } 200 \text { matrículas de } \\
\text { escolarização }\end{array}$ & $\begin{array}{lll}\text { Ensino } & \text { Fundamental, } & \text { Ensino } \\
\text { Médio, Educação de } & \text { Jovens } \\
\text { Adultos } & & \\
\end{array}$ \\
\hline $\begin{array}{l}\text { EE INDIGENA } \\
\text { EDUCBASICA } \\
\text { MAYROWI APIAKA } \\
\end{array}$ & 51093731 & Apiacás & $\begin{array}{l}\text { Entre } 51 \text { e } 200 \text { matrículas de } \\
\text { escolarização }\end{array}$ & $\begin{array}{lll}\text { Ensino } & \text { Fundamental, Ensino } \\
\text { Médio } & \end{array}$ \\
\hline
\end{tabular}




\begin{tabular}{|c|c|c|c|c|}
\hline $\begin{array}{l}\text { EE } \quad \text { INDIGENA } \\
\text { BEPKOROROTI }\end{array}$ & 51093987 & $\begin{array}{l}\text { São José do } \\
\text { Xingu }\end{array}$ & $\begin{array}{l}\text { Entre } 51 \text { e } 200 \text { matrículas de } \\
\text { escolarização }\end{array}$ & $\begin{array}{lll}\text { Ensino } & \text { Fundamental, } & \text { Ensino } \\
\text { Médio, Educação de } & \text { Jovens } \\
\text { Adultos } & & \end{array}$ \\
\hline $\begin{array}{lr}\text { EE } & \text { INDIGENA } \\
\text { CENTRAL } & \text { EDUC } \\
\text { BASICA KISEDJE } \\
\end{array}$ & 51094002 & Querência & $\begin{array}{l}\text { Entre } 51 \text { e } 200 \text { matrículas de } \\
\text { escolarização }\end{array}$ & $\begin{array}{l}\text { Ensino Fundamental, Educação } \\
\text { de Jovens Adultos }\end{array}$ \\
\hline $\begin{array}{lr}\text { EE } & \text { INDIGENA } \\
\text { CENTRAL } & \text { EDUC } \\
\text { BASICA KAMADU } \\
\end{array}$ & 51094010 & Marcelândia & $\begin{array}{l}\text { Entre } 51 \text { e } 200 \text { matrículas de } \\
\text { escolarização }\end{array}$ & $\begin{array}{lll}\text { Ensino } & \text { Fundamental, Ensino } \\
\text { Médio } & \end{array}$ \\
\hline $\begin{array}{l}\text { EE INDIGENA JULA } \\
\text { PARE }\end{array}$ & 51094150 & $\begin{array}{l}\text { Barra do } \\
\text { Bugres }\end{array}$ & $\begin{array}{l}\text { Entre } 51 \text { e } 200 \text { matrículas de } \\
\text { escolarização }\end{array}$ & $\begin{array}{lll}\text { Ensino } & \text { Fundamental, } & \text { Ensino } \\
\text { Médio, Educação de } & \text { Jovens } \\
\text { Adultos } & & \\
\end{array}$ \\
\hline $\begin{array}{ll}\text { EE INDIGENA } & \text { KURA } \\
\text { BAKAIRI } & \end{array}$ & 51094932 & Paranatinga & $\begin{array}{l}\text { Entre } 51 \text { e } 200 \text { matrículas de } \\
\text { escolarização }\end{array}$ & $\begin{array}{lll}\text { Ensino Fundamental, } & \text { Ensino } \\
\text { Médio, Educação de } & \text { Jovens } \\
\text { Adultos } & & \\
\end{array}$ \\
\hline $\begin{array}{ll}\text { EE } & \text { INDIGENA } \\
\text { ALDEIONA } & \end{array}$ & 51094940 & Campinápolis & $\begin{array}{l}\text { Entre } 201 \text { e } 500 \text { matrículas de } \\
\text { escolarização }\end{array}$ & $\begin{array}{lll}\text { Ensino } & \text { Fundamental, } & \text { Ensino } \\
\text { Médio, Educação de } & \text { Jovens } \\
\text { Adultos } & & \\
\end{array}$ \\
\hline $\begin{array}{lrr}\text { EE } & \text { INDIGENA } & \text { DE } \\
\text { EDUC } & \text { BASICA } \\
\text { MARAIWATSEDE } & \end{array}$ & 51094975 & $\begin{array}{l}\text { Bom Jesus do } \\
\text { Araguaia }\end{array}$ & $\begin{array}{l}\text { Entre } 201 \text { e } 500 \text { matrículas de } \\
\text { escolarização }\end{array}$ & $\begin{array}{lll}\text { Ensino } & \text { Fundamental, Ensino } \\
\text { Médio } & \end{array}$ \\
\hline $\begin{array}{l}\text { EE INDIGENA DE } \\
\text { EDUCACAO BASICA } \\
\text { MYHYINYMYKYTA } \\
\text { SKIRIPI }\end{array}$ & 51095041 & Brasnorte & $\begin{array}{l}\text { Entre } 501 \text { e } 1000 \text { matrículas } \\
\text { de escolarização }\end{array}$ & $\begin{array}{lll}\text { Ensino } & \text { Fundamental, } & \text { Ensino } \\
\text { Médio, Educação de } & \text { Jovens } \\
\text { Adultos } & & \end{array}$ \\
\hline $\begin{array}{llr}\text { EE } & \text { INDIGENA } & \text { DE } \\
\text { EDUCACAO } & \text { BASICA } \\
\text { PIYULAGA } & \\
\end{array}$ & 51095050 & $\begin{array}{l}\text { Gaúcha do } \\
\text { Norte }\end{array}$ & $\begin{array}{l}\text { Entre } 51 \text { e } 200 \text { matrículas de } \\
\text { escolarização }\end{array}$ & $\begin{array}{lll}\text { Ensino } & \text { Fundamental, Ensino } \\
\text { Médio } & \end{array}$ \\
\hline EE INDIGENA HAMBE & 51095068 & $\begin{array}{l}\text { Barra do } \\
\text { Garças }\end{array}$ & $\begin{array}{l}\text { Entre } 51 \text { e } 200 \text { matrículas de } \\
\text { escolarização }\end{array}$ & $\begin{array}{lll}\text { Ensino } & \text { Fundamental, } & \text { Ensino } \\
\text { Médio, Educação de } & \text { Jovens } \\
\text { Adultos } & & \\
\end{array}$ \\
\hline $\begin{array}{l}\text { EE INDIGENA DE } \\
\text { EDUCACAO BASICA } \\
\text { MALAMALATI } \\
\end{array}$ & 51095076 & $\begin{array}{l}\text { Tangará da } \\
\text { Serra }\end{array}$ & $\begin{array}{l}\text { Entre } 51 \text { e } 200 \text { matrículas de } \\
\text { escolarização }\end{array}$ & Ensino Médio \\
\hline $\begin{array}{l}\text { EE } \text { INDIGENA } \\
\text { PAIHITWARA }\end{array}$ & 51095084 & Paranatinga & $\begin{array}{l}\text { Entre } 201 \text { e } 500 \text { matrículas de } \\
\text { escolarização }\end{array}$ & $\begin{array}{lll}\text { Ensino } & \text { Fundamental, } & \text { Ensino } \\
\text { Médio, Educação de } & \text { Jovens } \\
\text { Adultos } & & \\
\end{array}$ \\
\hline $\begin{array}{llr}\text { EE } & \text { INDIGENA } & \text { DE } \\
\text { EDUCACAO } & \text { BASICA } \\
\text { METUKTIRE } & \\
\end{array}$ & 51100002 & $\begin{array}{l}\text { Peixoto de } \\
\text { Azevedo }\end{array}$ & $\begin{array}{l}\text { Entre } 51 \text { e } 200 \text { matrículas de } \\
\text { escolarização }\end{array}$ & $\begin{array}{l}\text { Ensino Fundamental, Ensino } \\
\text { Médio }\end{array}$ \\
\hline $\begin{array}{lr}\text { EE } & \text { INDIGENA } \\
\text { EDUCACAO } & \text { BASICA } \\
\text { ZARUP WEJ } & \\
\end{array}$ & 51106809 & Rondolândia & $\begin{array}{l}\text { Entre } 51 \text { e } 200 \text { matrículas de } \\
\text { escolarização }\end{array}$ & $\begin{array}{l}\text { Ensino Fundamental, Ensino } \\
\text { Médio }\end{array}$ \\
\hline $\begin{array}{l}\text { EE INDIGENA } \\
\text { SERTANISTA APOENA } \\
\text { MEIRELLES } \\
\end{array}$ & 51109000 & Rondolândia & $\begin{array}{l}\text { Até } 50 \text { matrículas } \mathrm{de} \\
\text { escolarização }\end{array}$ & $\begin{array}{l}\text { Ensino Fundamental, Ensino } \\
\text { Médio }\end{array}$ \\
\hline $\begin{array}{lll}\text { EE } & \text { INDIGENA } \\
\text { BAROMPO } & \\
\end{array}$ & 51110202 & Juara & $\begin{array}{l}\text { Entre } 51 \text { e } 200 \text { matrículas de } \\
\text { escolarização }\end{array}$ & $\begin{array}{l}\text { Ensino Fundamental, Ensino } \\
\text { Médio }\end{array}$ \\
\hline $\begin{array}{ll}\text { ESCOLA } & \text { ESTADUAL } \\
\text { INDIGENA ITAWYAK }\end{array}$ & 51110814 & Apiacás & $\begin{array}{l}\text { Entre } 51 \text { e } 200 \text { matrículas de } \\
\text { escolarização }\end{array}$ & $\begin{array}{l}\text { Ensino Fundamental, Ensino } \\
\text { Médio }\end{array}$ \\
\hline $\begin{array}{lrr}\text { EE } & \text { INDIGENA } & \text { DE } \\
\text { EDUCACAO } & \text { BASICA } \\
\text { HAWALORA } & \\
\end{array}$ & 51111608 & $\begin{array}{l}\text { Santa } \\
\text { Terezinha }\end{array}$ & $\begin{array}{l}\text { Entre } 51 \text { e } 200 \text { matrículas de } \\
\text { escolarização }\end{array}$ & $\begin{array}{lll}\text { Ensino } & \text { Fundamental, } & \text { Ensino } \\
\text { Médio, Educação de } & \text { Jovens } \\
\text { Adultos } & & \\
\end{array}$ \\
\hline $\begin{array}{lr}\text { EE } & \text { INDIGENA } \\
\text { EDUCACAO } & \text { BASICA } \\
\text { PANAKU } & \\
\end{array}$ & 51130807 & Marcelândia & $\begin{array}{l}\text { Entre } 51 \text { e } 200 \text { matrículas de } \\
\text { escolarização }\end{array}$ & Ensino Fundamental \\
\hline $\begin{array}{l}\text { EE INDIGENA TERENA } \\
\text { DE KOMOMOYEA } \\
\text { KOVOERO } \\
\end{array}$ & 51162857 & Matupá & $\begin{array}{l}\text { Entre } 51 \text { e } 200 \text { matrículas de } \\
\text { escolarização }\end{array}$ & $\begin{array}{lll}\text { Ensino } & \text { Fundamental, Ensino } \\
\text { Médio, Educação de } & \text { Jovens } \\
\text { Adultos } & & \\
\end{array}$ \\
\hline $\begin{array}{l}\text { EE INDIGENA } \\
\text { MAMAINDE }\end{array}$ & 51166860 & Comodoro & $\begin{array}{l}\text { Entre } 51 \text { e } 200 \text { matrículas de } \\
\text { escolarização }\end{array}$ & $\begin{array}{lll}\text { Ensino } & \text { Fundamental, } & \text { Ensino } \\
\text { Médio, Educação de } & \text { Jovens } \\
\text { Adultos } & & \\
\end{array}$ \\
\hline $\begin{array}{lr}\text { EE INDIGENA } & \text { LUIZ } \\
\text { RUDZANE } & \text { EDI } \\
\text { OREBWE } & \\
\end{array}$ & 51172801 & Campinápolis & $\begin{array}{l}\text { Entre } 51 \text { e } 200 \text { matrículas de } \\
\text { escolarização }\end{array}$ & $\begin{array}{lll}\text { Ensino } & \text { Fundamental, } & \text { Ensino } \\
\text { Médio, Educação de } & \text { Jovens } \\
\text { Adultos } & & \\
\end{array}$ \\
\hline
\end{tabular}




\begin{tabular}{|l|l|l|l|l|ll|}
\hline $\begin{array}{l}\text { EE INDIGENA } \\
\text { CHIQUITANO JOSE } \\
\text { TURIBIO }\end{array}$ & 51190800 & $\begin{array}{l}\text { Porto } \\
\text { Esperidião }\end{array}$ & $\begin{array}{l}\text { Até } 50 \text { matrículas de } \\
\text { escolarização }\end{array}$ & $\begin{array}{l}\text { Ensino Fundamental, Ensino } \\
\text { Médio }\end{array}$ & \\
\hline $\begin{array}{l}\text { EE INDIGENA EDUC } \\
\text { BASICA ATURUA }\end{array}$ & 51190940 & Paranatinga & $\begin{array}{l}\text { Até } 50 \text { matrículas de } \\
\text { escolarização }\end{array}$ & $\begin{array}{l}\text { Ensino Fundamental, Ensino } \\
\text { Médio, Educação de Jovens } \\
\text { Adultos }\end{array}$ \\
\hline
\end{tabular}


Anexo 3 - Relação de escolas quilombolas estaduais

\begin{tabular}{|c|c|c|c|c|}
\hline Escola & $\begin{array}{l}\text { Código } \\
\text { INEP }\end{array}$ & Município & Porte da Escola & $\begin{array}{l}\text { Etapas e Modalidade de Ensino } \\
\text { Oferecidas }\end{array}$ \\
\hline $\begin{array}{l}\text { EE VERENA } \\
\text { LEITE DE } \\
\text { BRITO }\end{array}$ & $\begin{array}{l}5102563 \\
9\end{array}$ & $\begin{array}{l}\text { Vila Bela da } \\
\text { Santíssima } \\
\text { Trindade }\end{array}$ & $\begin{array}{lr}\text { Mais de } & 1000 \\
\text { matrículas } & \text { de } \\
\text { escolarização }\end{array}$ & $\begin{array}{l}\text { Ensino Fundamental, Ensino } \\
\text { Médio, Educação Profissional, } \\
\text { Educação de Jovens Adultos }\end{array}$ \\
\hline $\begin{array}{l}\text { EE } \\
\text { REUNIDAS } \\
\text { DE } \\
\text { CACHOEIRA } \\
\text { RICA }\end{array}$ & $\begin{array}{l}5103528 \\
6\end{array}$ & $\begin{array}{l}\text { Chapada dos } \\
\text { Guimarães }\end{array}$ & $\begin{array}{lr}\text { Entre } 51 \text { e } 200 \\
\text { matrículas } \\
\text { escolarização }\end{array}$ & 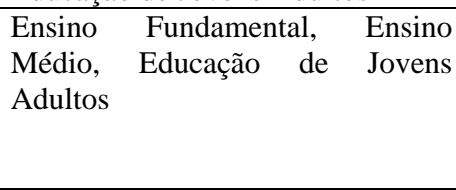 \\
\hline $\begin{array}{l}\text { EE MARIA } \\
\text { DE ARRUDA } \\
\text { MULLER }\end{array}$ & $\begin{array}{l}5108987 \\
4\end{array}$ & $\begin{array}{l}\text { Santo Antônio do } \\
\text { Leverger }\end{array}$ & $\begin{array}{l}\text { Entre } 201 \text { e } 500 \\
\text { matrículas de } \\
\text { escolarização }\end{array}$ & $\begin{array}{llll}\text { Ensino } & \text { Fundamental, } & \text { Ensino } \\
\text { Médio, } & \text { Educação de } & \text { Jovens } \\
\text { Adultos } & & & \\
\end{array}$ \\
\hline $\begin{array}{l}\text { EE TEREZA } \\
\text { CONCEICAO } \\
\text { ARRUDA } \\
\end{array}$ & $\begin{array}{l}5116880 \\
4\end{array}$ & $\begin{array}{l}\text { Nossa Senhora do } \\
\text { Livramento }\end{array}$ & $\begin{array}{lr}\text { Entre } 201 \text { e } 500 \\
\text { matrículas de } \\
\text { escolarização }\end{array}$ & $\begin{array}{lll}\text { Ensino } & \text { Fundamental, } & \text { Ensino } \\
\text { Médio, } & \text { Educação de } & \text { Jovens } \\
\text { Adultos } & & \\
\end{array}$ \\
\hline $\begin{array}{l}\text { EE JOSE } \\
\text { MARIANO } \\
\text { BENTO }\end{array}$ & $\begin{array}{l}5119081 \\
8\end{array}$ & Barra do Bugres & $\begin{array}{lrr}\text { Entre } 51 \text { e } & 200 \\
\text { matrículas } & \text { de } \\
\text { escolarização }\end{array}$ & $\begin{array}{llll}\text { Ensino } & \text { Fundamental, } & \text { Ensino } \\
\text { Médio, } & \text { Educação de } & \text { Jovens } \\
\text { Adultos } & & & \\
\end{array}$ \\
\hline
\end{tabular}

